Portland State University

PDXScholar

$1-1-2010$

\title{
Coal to Oil in China: Scientific Development or Crossing the River by Feeling the Stones?
}

Joseph John Narus

Portland State University

Follow this and additional works at: https://pdxscholar.library.pdx.edu/open_access_etds Let us know how access to this document benefits you.

\section{Recommended Citation}

Narus, Joseph John, "Coal to Oil in China: Scientific Development or Crossing the River by Feeling the Stones?" (2010). Dissertations and Theses. Paper 169.

https://doi.org/10.15760/etd.169

This Thesis is brought to you for free and open access. It has been accepted for inclusion in Dissertations and Theses by an authorized administrator of PDXScholar. Please contact us if we can make this document more accessible: pdxscholar@pdx.edu. 


\title{
Coal to Oil in China:
}

Scientific Development or Crossing the River by Feeling the Stones?

\section{By}

Joseph John Narus

A thesis submitted in partial fulfillment of the requirements for the degree of

\section{Master of Arts \\ in \\ Geography}

\author{
Thesis Committee: \\ Gil Latz, Chair \\ Jiunn-Der 'Geoffrey' Duh \\ Mel Gurtov \\ Martha Works
}

Portland State University

(C)2010 


\begin{abstract}
Since the start of the $21^{\text {st }}$ century, energy security concerns and rising international energy costs have led China to pursue the development of a coal to oil industry, whereby converting a portion of the nation's abundant coal reserves into gasoline, diesel, or jet fuel, China might be able to increase its domestic 'oil' production and generate profits. But a large-scale coal to oil industry exerts added pressure on China's domestic coal reserves and water resources, and generates significant greenhouse gas emissions. The tension between the potential benefits of coal to oil development and its associated negative externalities present a challenge for China's energy policymakers, who must balance competing demands for energy security, resource management, and equitable development. The challenge of effectively managing the development of this industry is complicated by the characteristic problems plaguing energy sector governance in China, including the absence of a powerful energy policymaking institution, the decentralized nature of the country's economic development, and the influence of large energy companies.

This study examines the evolution of China's coal to oil industry and the policies shaping its development in order to better understand energy sector governance in China and the complex challenges confronting policymakers as they strive to balance an array of competing demands. It finds that weak energy institutions and powerful domestic actors indeed hinder China's ability to efficiently formulate energy policies for the coal to oil industry, while considerations about the industry's environmental and resource impacts compel a cautious approach to development. China's incremental approach to formulating a long-term plan for the development of the coal to oil industry may, in the end, yield more effective policies.
\end{abstract}




\section{Acknowledgements}

I never imagined when I started my graduate studies at Portland State University (PSU) in the fall of 2005 that it would take almost five years to complete a Master of Arts in Geography. But after two years of coursework, two years of intensive language study in China, and nine months of thesis writing, I am only now, in the summer of 2010 , graduating. Nonetheless, I would not change anything about how my graduate education has unfolded, nor would I condense the past five years even if I could. Rather, I am extraordinarily thankful for the opportunities I have had since starting at PSU and have learned more than I ever hoped or planned when I began this degree. During this time I have benefited greatly from the support of many people.

I would like to thank Martha Works and Geoffrey Duh for contributing their time and expertise as members of my thesis committee, and Karin Waller for her continued support as I communicated with the department from afar the past three years. I am indebted to Jonathan Pease and Steve Wadley for introducing me to the Chinese language and for supporting me as I pursued both scholarships and opportunities to study advanced Chinese overseas. I would also like to thank Hiro Ito of the Economics Department for helping me to understand the economic foundations of East Asia's rapid development, and for being a friend and informal advisor.

I am grateful for the financial support I received from the Department of Geography's Dale and Coral Courtney Scholarship, Rockie Scholarship, and Price Fieldwork Award; from the D. Paul Fansler Memorial Scholarship; and from the David L. Boren National Security Education Program.

It is impossible for me to properly thank or express my appreciation for the two mentors who played such an important role in making my education at PSU a wonderful experience, both personally and professionally. Mel Gurtov has been a source of inspiration - for his principles, his sense of humor, and his humanity. He will forever be a role model that I strive to emulate. I am especially grateful and indebted to my primary advisor, Gil Latz, who accepted me as an advisee midway through my first year at PSU and who has since devoted countless hours to his role as mentor. His professionalism and thoughtfulness have made it a joy and honor to be his student, and I will benefit throughout my career from his example. It has been my privilege to study under Mel and Gil. It is an even greater privilege to consider them my friends.

Above all, I am grateful to my parents for their continued love and support. I would not be who I am or where I am without their guidance, and their belief in me has been an endless source of encouragement and assurance. Having them as parents is the greatest blessing of my life. 
Table of Contents

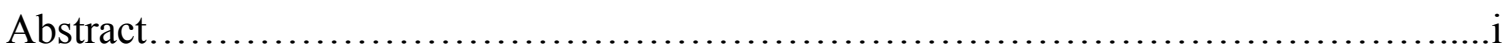

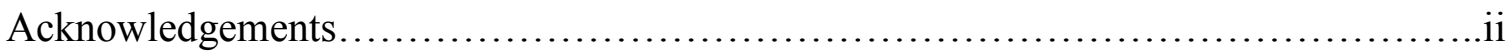

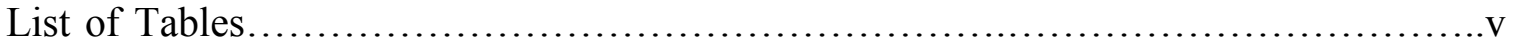

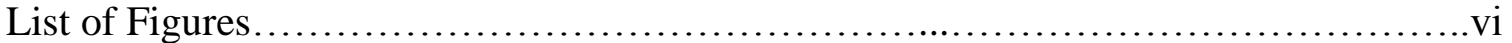

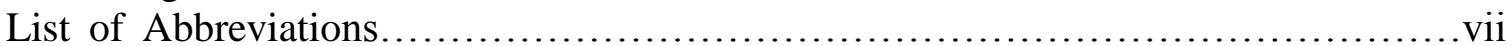

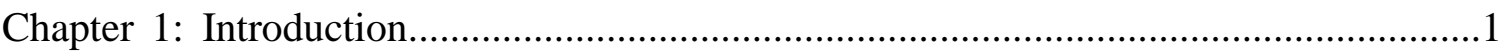

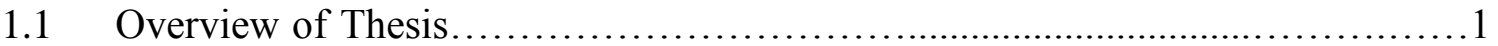

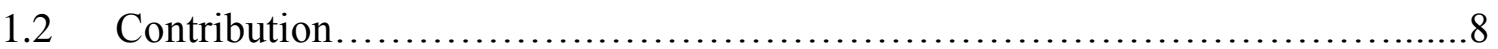

1.3 Research Methodology...............................................10

1.4 Research Barriers......................................................11

1.5 Thesis Committee Composition........................................ 14

Chapter 2: China's Energy Resource Endowment, Energy Security Policies, and Role of Coal Liquids.................................................. 15

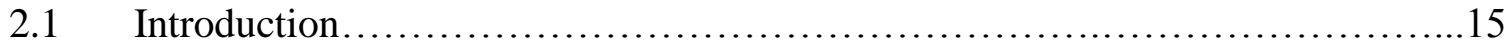

2.2 China's Energy Resource Endowment...................................... 15

2.3 China's Energy Security Dilemma..............................................19

2.4 The Meaning of Energy Security in China................................22

2.5 China's Response to its Energy Security Dilemma and the Role of Alternative

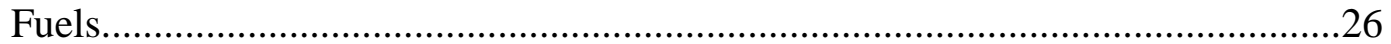

2.6 Defining Coal to Oil and Imposing Limitations on the Scope of This Study.....27

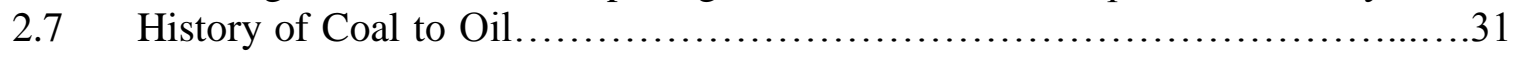

2.8 Coal to Oil Processes: Direct and Indirect................................... 32

2.9 Coal to Oil Resource Impacts and Economics................................33

2.9.1 Coal Consumption................................................... 33

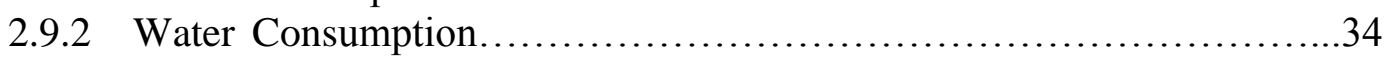

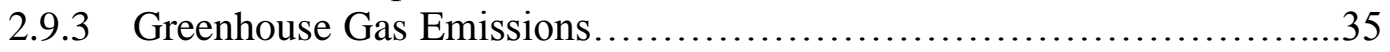

2.9.4 Economics .......................................................

2.10 Geographical Prerequisites for Building a Coal to Oil Plant....................38

2.11 Why CTL is an Attractive Strategy for China............................. 40

Chapter 3: Energy Policymaking in China: Three Core Challenges................................42

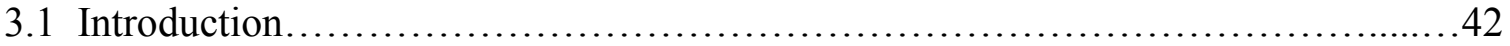

3.2 Fragmented and Weak Bureaucracies........................................43

3.3 Powerful Energy Companies.....................................................46

3.4 Challenges of Decentralization........................................... 49 


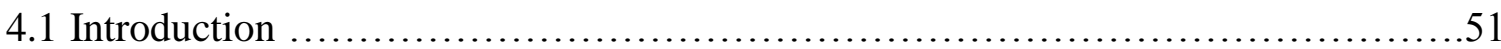

4.2 Early History of Coal to Oil Development in China..................................51

4.2 The Evolution of China's Coal to Oil Industry and Policies...........................54

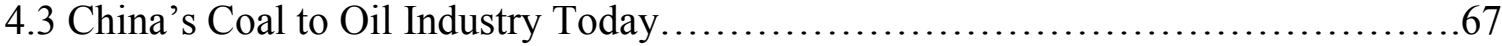

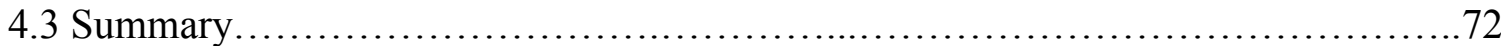

Chapter 5: Analysis - Focus on Resource and Environmental Issues....................75

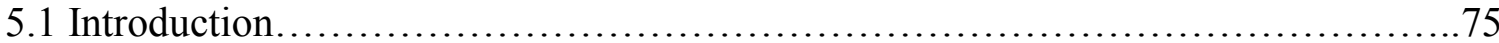

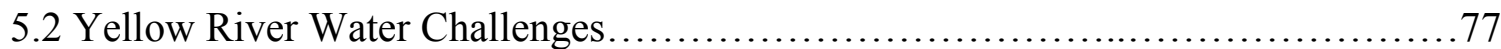

5.3 Managing Greenhouse Gas Emissions.......................................... 81

5.4 The Challenge of Sustainably Managing China's Coal Resources..................83

5.5 Assessing the Central Government's Efforts to Address the Environmental and Resource Challenges Associated with Coal to Oil Development.................................86

5.6 Efforts to Mitigate Water Resource Impacts from Coal to Oil............................86

5.7 Efforts to Address Coal to Oil Greenhouse Gas Emissions................................90

5.8 Recognition of Coal to Oil's Demand Pressures on Coal Reserves.......................92

5.9 Central Government Recognition of the Challenges Posed by Coal to Oil's Resource

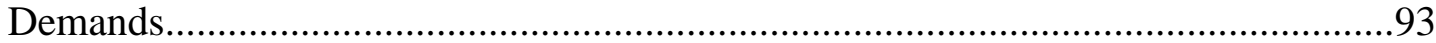

Chapter 6: Key Findings and Implications................................................................95

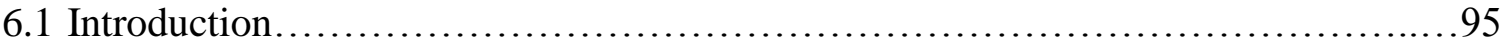

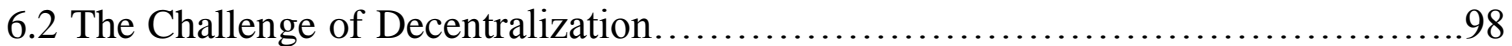

6.3 Influential Energy Companies................................................ 100

6.4 China's Energy Policymaking Process........................................ 107

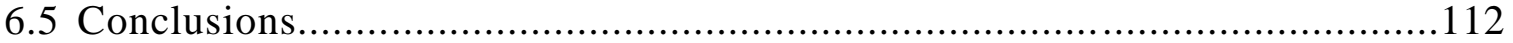

6.6 The Future of Coal to Oil in China................................................ 114

6.7 Implications of Coal to Oil in China and Beyond....................................115

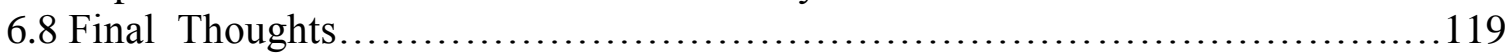

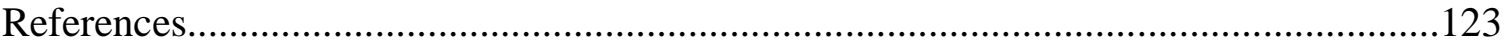

Appendices

A. Future Outlook for China's Coal to Oil Industry..........................135 


\section{List of Tables}

Table 1. China's Five Flagship Coal to Oil Projects, 2010............................ 72 


\section{List of Figures}

Figure 1. Energy Content of China's Fossil Fuel Reserve Base, 2007....................17

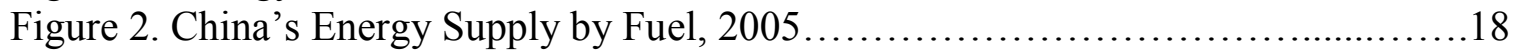

Figure 3. China's Oil Balance in the IEA 2007 World Energy Outlook Reference

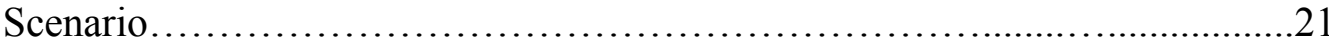

Figure 4. Comparing the Greenhouse Gas Emissions of Different Fuels..................36

Figure 5. Approximate Location of Ordos, Inner Mongolia and Pingdingshan, Henan....53

Figure 6. Approximate Location of the Ningdong Coal Chemical Base, Ningxia and

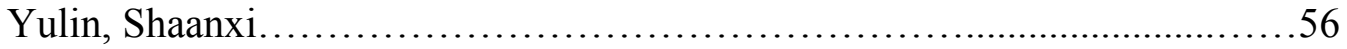

Figure 7. Approximate Location of China's Largest Substitute Fossil-Fuel Production Base........................................................................61

Figure 8. Approximate Representation of Yellow River basin and the Location of China's Five Flagship Coal to Oil Projects....................................74

Figure 9. Primary Energy Demand - People's Republic of China......................83

Figure 10. Coal Production in China - Scenario Based on Present Reserve

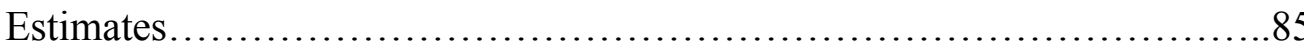


List of Abbreviations

$\begin{array}{ll}\text { bpd } & \text { Barrels per day } \\ \text { CCP } & \text { Chinese Communist Party } \\ \text { EIA } & \text { Energy Information Administration (United States Department of Energy) } \\ \text { mta } & \text { Million tons per annum } \\ \text { MTOE } & \text { Million tons of oil equivalent } \\ \text { NDRC } & \text { National Development and Reform Commission } \\ \text { NEA } & \text { National Energy Administration } \\ \text { DOE } & \text { Department of Energy (United States) }\end{array}$




\section{Chapter 1: Introduction}

\subsection{Overview of Thesis}

China's remarkable economic growth over the past thirty years has led to dramatic increases in energy demand, threatening China's ability to maintain adequate access to energy supplies. This trend has been the focus of much attention and concern both inside and outside of China over the past ten years. Concerns center on the strains China's growing energy demand is placing on world energy supplies; the environmental impact of China's energy consumption, particularly in relation to global climate change; and the geopolitical implications of China's emergence as a new player in the world's energy security calculus. These concerns have led to a renewed interest in the policies

governing China's sector and how they attempt to take into account not only the issue of energy security, but also the needs to maintain stable macro-economic growth, improve environmental sustainability, and promote equitable development. These issues overlap with core interests of the central government and Chinese Communist Party (CCP), including the Party's ability to stay in power, maintain social stability, and sustain China's trajectory toward great power status. In short, effective energy policies that balance competing domestic demands with the need for energy security are essential both to China's continued rise and the survival of the CCP.

Energy resource distribution in China both constrains and informs decisions about energy policy. Many of the energy challenges facing leaders in Beijing are the direct result of China's distinct natural resource endowment, and Chinese policymakers 
must contend with geographical realities as they determine how to meet national energy needs. Geographical issues confronting policy makers include the unequal distribution of China's energy resources endowment, including coal, oil, and natural gas; the distance between production bases and consumption areas; competing demands for scarce or finite resources in energy production areas; and balancing China's national-level energy resource demands with the needs of local populations and environmental concerns. Under ideal circumstances, market mechanisms determine how these issues are overcome or accounted for, and when market mechanisms cannot balance competing priorities, the political process creates rational and coherent solutions that effectively relate natural resources to national objectives. But China's energy sector (like that of other countries) does not function under ideal conditions, and the management of energy resources and the making of energy policy are shaped by a number of inputs, factors and constraints, both domestic and external (Meidan, 2007, 36). The distribution of resources in China creates some of China's energy challenges and shapes decisions about how to address them, but it is only one factor among many that influences energy policy.

The common perception of China's approach to managing its energy endowment is generally assumed to be as follows: the central government is firmly in control of energy policy, the term "state owned" equates to "state controlled," and an authoritarian, top-down vertical Chinese state structure creates strategic purpose and coherence in the energy policy making arena (Cunningham, 2007). This perception fits the rational decision-making model where "decisions would be made by a group of individuals with a common set of values through the rational analysis of a problem and the evaluation of 
alternative solutions" (Lieberthal and Oksenberg, 1988). However, this perception does not match reality. According to those who have studied closely China's energy policymaking process, China's energy policies and energy institutions are fragmented, ineffective, decentralized, ad hoc, reactive, and subject to the interests of powerful domestic actors and stakeholders (Lieberthal and Oksenberg, 1988; Andrews-Speed, 2004). Most importantly, it is simplistic to reflexively attribute every development in China's energy sector, at home or abroad, to highly coordinated strategic planning originating from the center.

To better understand how energy policy is made and executed in China, and the different factors that inform the process, scholars have carried out numerous case-studies on China's energy institutions, the energy policy making process, and specific aspects of China's energy sector. In the aggregate, these studies reveal energy institutions that are unable to formulate and implement a coherent national energy policy, fierce competition between competing interests and stakeholders, and a central government struggling to govern and control events on the ground.

Of the many different inputs to the system that must be accounted for in the study of Chinese energy policy making, the composition and distribution of China's energy and natural resources is one the most important as it sets the parameters of the debate and limits policy options. A government can choose how to allocate or exploit energy resources, but it cannot create resources where there are none. At the same time, how and where energy resources are exploited often directly impacts other natural resources and the local environment. China's energy policies, then, attempt to balance the 
opportunities and constraints posed by energy resource endowments, domestic economic and social issues, and the conditions of the larger international geopolitical environment. The reverse is true as well; decisions about how to develop and exploit China's energy resources invariably affect other social, economic, resource, and geopolitical issues.

One emerging industry that has not been studied in depth but can provide important insights into Chinese energy policies and the competing energy and resource challenges confronting policymakers is China's nascent coal-to-oil industry (hereafter referred to as coal to oil), the process of converting coal into gasoline and diesel. Coal to oil, for reasons that will be explained further in the chapters that follow, is often thought of as an energy security strategy whereby converting coal into synthetic oil products a country can reduce its reliance on oil imports and enhance the reliability and predictability of its oil supplies. Coal to oil projects in China are often framed in this context, but the industry also brings into play many of the key dynamics thought to influence the processes and outcomes of de facto and national-level energy policy making in China, including the distribution of energy resources, and is of potentially great significance to China's energy security, sustainable development, and social stability.

Despite the political and environmental salience of this industry, and the spasmodic nature of its early development, a comprehensive survey of the industry's relatively short history, the geographic and resource issues shaping its development, and means by which the central government has managed its development has yet to be conducted. This study will attempt to fill that void, and will seek to address three key 
questions. First, do the energy policies governing the development of the coal to oil industry in China reflect awareness on the part of the central government of the potentially negative environmental and resource impacts of coal to oil development in China? Second, how has the government attempted to balance resource and environmental constraints with the potential benefits of coal to oil? Third, what does the government's management of this industry reveal about energy sector governance in general? To answer these questions, this study will analyze the evolution of the coal to oil industry and the policies guiding its development between 2000 and 2010, and will explore how these policies account for (or do not account for) three of the key resource and environmental concerns that this industry will affect: water resources, coal resources, and greenhouse gas emissions. In answering these core questions, several additional topics will be explored in depth. First, how does China's energy resource endowment affect China's energy security outlook? Second, what is coal to oil and why is it part of China's strategy for improving energy security? And finally, how effectively is the government balancing the competing demands of energy security and sustainable development in relation to the coal to oil industry, and what are the other factors that are influencing how this process unfolds?

This study has six chapters. Following the introduction, chapter two provides background on how China's distinct natural resource endowment shapes the country's energy security outlook and the concomitant problem of energy insecurity, and why coal to oil is being considered as part of China's strategy for improving its energy security. China's primary source of energy insecurity is its growing reliance on imported oil, and 
China's relatively small oil reserves limit the government's ability to increase domestic oil production to offset growth in demand. These observations serve as background to why abundant coal reserves may provide an alternative path for increasing domestic liquid fuel production through the process known as coal to oil. After surveying China's energy security and resource landscape, the second half of the chapter introduces the coal to oil process, discusses the reemergence of this industry as a result of global energy supply and demand trends, and explains why coal to oil is an attractive strategy in the context of China's domestic energy reserves and the international geopolitical environment. The chapter will close with an outline of the demands this industry places on coal resources, water resources, and the environment.

In chapter three, I review the literature on China's energy policymaking process and outline the main conclusions of previous studies and research in this field. The goal of this section is to shed light on factors other than China's resource endowment and energy security concerns that directly and indirectly shape energy policy and resource management. These factors include powerful state-owned energy companies, government institutions and bureaucracies, and relations between the central government and the provinces. Understanding the challenges and forces confronting Chinese policymakers and energy institutions requires dissecting a complex set of issues, including those associated with China's unique energy geography. This chapter lays the groundwork for later analysis of how the coal to oil industry has been managed.

In chapter four, I describe the evolution and present state of the coal to oil industry in China. To do so I provide background on the early history of China's coal to 
oil program and describe in detail how the industry has grown over the past ten years. I will focus specifically on the years between 2004 and the present (mid-year, 2010) and will use news reports, journal articles, and government and industry announcements to create a timeline that outlines the major projects, the specifics of their development, and the policies and directives used to shape the industry's evolution. In addition to describing key events and projects, I examine the arguments made by actors within China for why coal to oil should or should not develop, the dynamics surrounding the industry, and the attitudes of the stakeholders involved. At the conclusion of the chapter I will describe the present status of the industry as of mid-year, 2010.

In chapter five, I provide background on three of the major resource and environmental issues this industry will affect, which are coal resources, water resources, and greenhouse gas emissions. In this section I provide background on the water challenges facing the Yellow River basin, the location of China's coal to oil project development; the associated risks climate change poses to China and how China is addressing its greenhouse gas emissions problem; and the makeup and outlook of China's coal resources. Next, I discuss how coal to oil development will affect each of these issues. Finally, I explore how the government has or has not attempted to account for the impact of coal to oil in each of these three areas. The purpose of this section will be to identify the key resource and environmental issues in play and to determine whether or not the central government is aware of and responding to the challenges posed by coal to oil development. 
In the sixth and final chapter, I explain my observations and findings on energy policymaking in the coal to oil industry and compare those observations with the literature on China's energy policy and policymaking. I also combine analysis of the situation with my own interpretation of how to understand the government's predicament, why it has responded the way it has, and whether or not that response has been successful or logical. Finally, I discuss the implications of coal to oil development for China and the world, provide my own view on the matter, and offer some closing thoughts.

\subsection{Contribution}

How China's energy sector develops over the coming two decades (2010-2030) will play a significant role in determining whether or not the planet is able to avert the worst consequences of global climate change. China has already surpassed the United States in total greenhouse gas emissions and by 2040 China will be the largest cumulative historical emitter of carbon in spite of its relatively late start (Lieberthal, 2009). China is already making great strides in developing clean sources of energy, improving energy efficiency, and reducing carbon intensity, strides that are the result of specific energy policies originating in Beijing. Nonetheless, China (like the United States) has a long road ahead if it is going to reduce emissions to sustainable levels. How China manages its energy resources and formulates its energy policies will play a vital role in this process.

This research is the first in-depth research to be conducted on the evolution of China's coal to oil industry and the policies guiding its development. Numerous studies 
have looked at more popular aspects of China's energy sector, such as renewable energy, China's national oil companies, and China's growing natural gas consumption. China's energy security problem and strategies have also been written about and discussed in great length. But with coal to oil, most articles have focused mainly on the technical or economic aspects of the industry. No study that I am aware of has yet looked closely at the ongoing evolution of China's coal to oil industry, how China's resource geography has created some of the challenges facing the industry, or what the governance of this industry reveals about China's energy and resource management policies in general. In short, there is a gap in the literature about China's coal to oil industry, despite the significance of this industry to China's future development.

By analyzing how China is managing the development of this relatively new component of its energy sector this study will make three main contributions to the literature. First, it will record and describe the early evolution of China's coal to oil industry and the specific steps the government has taken to influence or adjust the trajectory of its development. Second, it will contribute to the larger body of knowledge on China's energy policies, the factors influencing energy policymaking, and China's methods for managing energy resources. Finally, this study will help inform those studying the future direction of China's energy sector, environment, and carbon emissions. 


\subsection{Research Methodology}

Research for this study was conducted in China and the United States from 2006 to 2010. From 2006-07, while at Portland State University, I began exploring this subject as a result of my interest in the impact coal to oil might have on China's environment, its carbon emissions, and its energy security. Between fall 2007 and fall 2009, while studying Mandarin Chinese intensively in Changchun (Jilin Province) and Beijing, I continued following this industry and researching all aspects of China's energy sector as a way to understand the position of coal to oil projects. Much of this research was informal and took a variety of different forms, including attending over a dozen energy conferences of varying size in China; informally interviewing Chinese and foreign experts about coal to oil technologies and how the industry related to China's overall energy sector; and using Chinese-language publications on coal to liquids and China's energy policies in my Chinese classes. My research also benefited from the fact that from 2008-09 I was a student at Tsinghua University, China's foremost research university for energy and climate issues, which gave me ample opportunity to meet Chinese and foreign professors knowledgeable about coal to oil and China's energy sector and to include the study of energy topics in my formal language training.

This informal research was buoyed by the time I spent interning at the U.S. Department of Energy's (DOE) Beijing Office in the summer of 2009. In this capacity I was able to participate in meetings between DOE and important actors in the coal to oil sector, such as the Shenhua Group and Sasol; interact with and interview some of the leading experts on coal to oil and carbon capture and storage technologies in the world; 
and attend meetings with high-ranking officials from the energy departments of both countries. As the information obtained through these activities and interviews was off the record and informal, none will be cited in this study. Nonetheless, they helped inform my overall understanding of the coal to oil industry, how it is developing in China today, and the factors driving or slowing its development.

Since returning from China in September 2009, I have read dozens of Chineselanguage journal articles, news reports, and government announcements related to coal to oil. The information used in this study and cited throughout consists primarily of government policy pronouncements, industry press releases, news articles, and scholarly research. Both English and Chinese language sources are used and the translations are my own.

\subsection{Research Barriers}

By choosing what in hindsight is a very challenging subject to study, I encountered numerous obstacles. Arguably the most significant has been learning the details of an extraordinarily complex subject that is typically the domain of engineers. As will be discussed in greater depth later, "coal to liquids" (of which coal to oil is one component) is a broad field that incorporates everything from "coal to methanol" to "coal to dimethyl ether" - essentially any process that converts coal into a liquid of any form (or a gaseous intermediary for later conversion to a liquid). Coal to liquids is also part of a larger industry, known as the "coal chemical" industry, which in addition to coal to liquids incorporates a range of coal gasification processes, including coal to natural gas and the 
production of coke, calcium carbide, and ammonia. Coal can be converted into a wide array of products through the use of different engineering processes, and each process has its own unique energy, resource, and environmental implications. These products can then be used for purposes as diverse as making plastics, generating electricity, or powering an automobile, and they can be blended, upgraded, and refined. Thus, formulating a research topic that is manageable in scope and academically sound within this field has required a methodical approach that included an enormous amount of independent research and reading. While only a subset of the knowledge gained in this process will be conveyed in this thesis, the background research was necessary in order to grasp and contextualize the final topic, coal to oil. All of this research and learning was done independently without formal classes or close mentoring by subject-matter experts.

A second challenge has been researching an industry that is still developing and is a moving target. Over the past four years it has alternately appeared that the government was either fully behind developing a massive coal to oil industry or that it was halting all development. Conflicting reports about the actual status of different coal to oil projects or plans for the industry abound, and often articles appearing at almost the same time in the media were in direct contradiction to each other. Equally challenging is the fact that many projects have been "announced" over the years, which can mean any number of things, including that that a company is speculating about developing a project, that a feasibility study is underway but no construction has taken place, that a project has been started but government approval has not been received, or that a project has started 
production. Considerable research and the comparison of contrasting reports is required in order to be able to determine the actual status of an announced project.

Finally, a third significant research barrier is that this study is focused wholly on China. As is well known by those who have conducted research on China, information is not always readily available, what information is available may not be accurate, and much of what is available is only published in Chinese. In addition, China is changing so rapidly that even those most informed about a subject, whether Chinese or foreign, likely do not know the full story or exactly what is happening. Early on in my research, one of my information sources observed that, "if somebody claims to know exactly what is happening in China, immediately discount anything they say. Nobody knows exactly what is happening in China, not even the Chinese themselves." I have found this to be more true than otherwise. China is so vast and its population so large that contradictions in policies and information abound. Two examples of this are China's one-child policy and the household registration (hukou) system. How these policies are applied often differs not only among provinces and regions in China, but often within provinces themselves. The same is true with energy policies and developments.

To facilitate my conducting of research on coal to oil and China's energy sector, I spent four years studying Mandarin Chinese, including two years of intensive language study in China. By the summer of 2009 I was able to read newspapers and scholarly articles and to conduct interviews with minimal translation assistance or use of the English language. The most significant benefit derived from this language training is the ability to read Chinese publications and conduct internet research using Chinese sources. 
Coal to oil receives nowhere near the press coverage in the West as do issues like energy security, climate change, or renewable energy. Therefore, trying to determine what is actually happening "on the ground" in China, both in terms of government policies and project developments, has required considerable research and reading of Chinese sources. Because of time and space considerations, only a small portion of that research will be included in this study, but without the ability to read Chinese I would not have been able to dive as deeply into this subject. At times I have used the Chinese language text translation software Wenlin and Google Translate to assist in my research.

\subsection{Committee Composition}

My thesis committee is composed of my primary advisor, Gil Latz, Professor of Geography and Vice Provost for International Affairs; Martha Works, Professor of Geography; Jiunn-Der 'Geoffrey' Duh, Assistant Professor of Geography; and Mel Gurtov, Professor Emeritus of Political Science. 
Chapter 2: China's Energy Resource Endowment, Energy Security Policies, and Role of

\section{$\underline{\text { Coal to Liquids }}$}

\subsection{Introduction}

The purpose of this chapter is to provide the background information necessary to understand why coal to oil is, at least in theory, an attractive energy strategy for China. China's pursuit of a coal to oil industry is driven by a combination of long-term economic trends, its resource endowment, and foreign policy considerations. As this chapter will show, the idea of converting coal into synthetic oil as an energy security strategy is perfectly rational within the context of China's current domestic and international conditions. This chapter will explore the different macro-level trends driving China to explore coal to oil projects, and will provide background about coal to oil technologies and the history of the industry.

\subsection{China’s Energy Resource Endowment}

China's rapid economic growth over the past 30 years has been described as one of the greatest economic success stories of modern times. The reforms that China initiated in the late 1970s have lifted hundreds of millions out of poverty and improved the living standards of many more.

From 1979 (when economic reforms began) to 2008, China's real gross domestic product (GDP) grew at an average annual rate of nearly 10\%. From 1980 to 2008, China's economy grew14-fold in real terms, real per capita GDP (a common measurement of living standards) grew over 11-fold, and hundreds of millions of people were raised out of extreme poverty. By some measurements, China is now 
the world's second largest economy and some analysts predict it could become the largest within a few decades. (Morrison, 2009, 1)

While this growth has benefited China and the world economy, it has also led to rapid growth in China's energy demand. Between 1990 and 2006, China's total primary energy demand grew from 863.2 million tons of oil equivalent (MTOE) to 1,878.7 MTOE in 2006, an average annual growth rate of 5.0\% (ADB, 2009, 148). The past decade in particular has seen a significant spike in demand. "Between 1978 and 2000 the Chinese economy grew at 9 percent while energy demand grew at 4 percent. After 2001, economic growth continued apace, but energy demand growth surged to 13 percent a year" (Rosen and Houser, 2007, 4). In spite of the challenges this has posed for China's energy infrastructure and energy reserves, China's energy resource endowment has, for the most part, enabled supply to keep up with demand.

China's energy resource endowment is distinguished by an abundance of coal and relatively small reserves of oil and gas. China's coal reserves, the third largest in the world after the United States and Russia (BP, 2010), have allowed China to maintain an energy self-sufficiency rate of over 90 percent (State Council Information Office, 2007), with coal completely dominating China's fossil fuel reserve base. China's fossil fuel reserve base consists of 2.8 billion tons of petroleum, 3.0 trillion cubic meters of natural gas, and 326 billion tons raw coal, meaning coal constitutes $97 \%$ of the fossil fuel reserve base by energy content (Figure 1). By contrast, in 2007, 62 percent of the world's conventional fossil fuel reserves were coal by energy content, with oil and natural gas each accounting for 19\% (Aden, Fridley, and Zheng, 2009). 


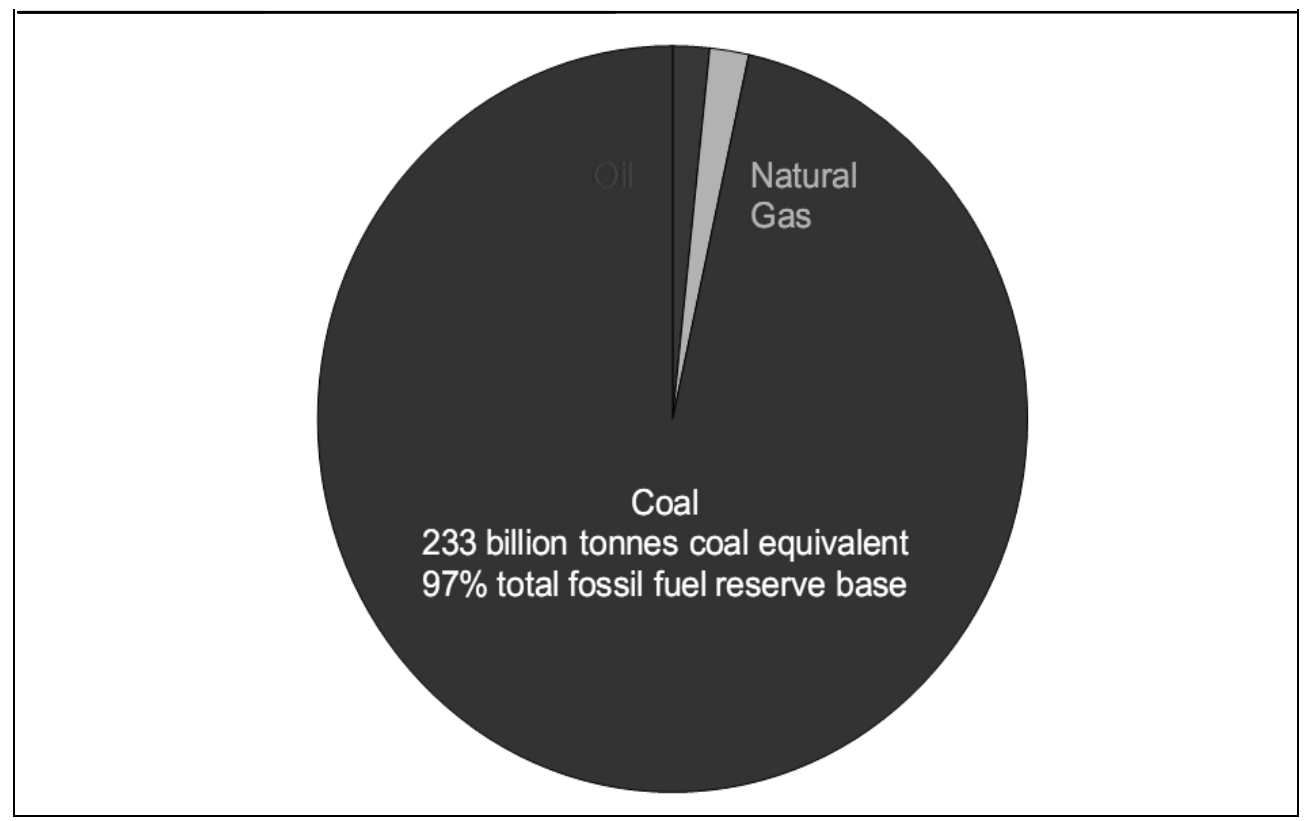

Source: Aden, Fridley, and Zheng, 2009, figure 2.

Figure 1. Energy Content of China's Fossil Fuel Reserve Base, 2007

This disproportionately large endowment of coal resources has led to coal becoming the backbone of China's energy sector, with oil, natural gas, and hydroelectric power rounding out the energy mix. The DOE's Energy Information Administration (EIA) estimated that coal, oil, gas, and hydroelectric power combined to make up over 98 percent of China's total energy consumption in 2006, with coal alone contributing 70 percent (2009). Nuclear energy and energy generated from wind, solar, and biomass are beginning to contribute more to China's energy sector, but their present contribution to China's overall energy sector remains small in relation to coal or other fossil fuels (Figure 2). 


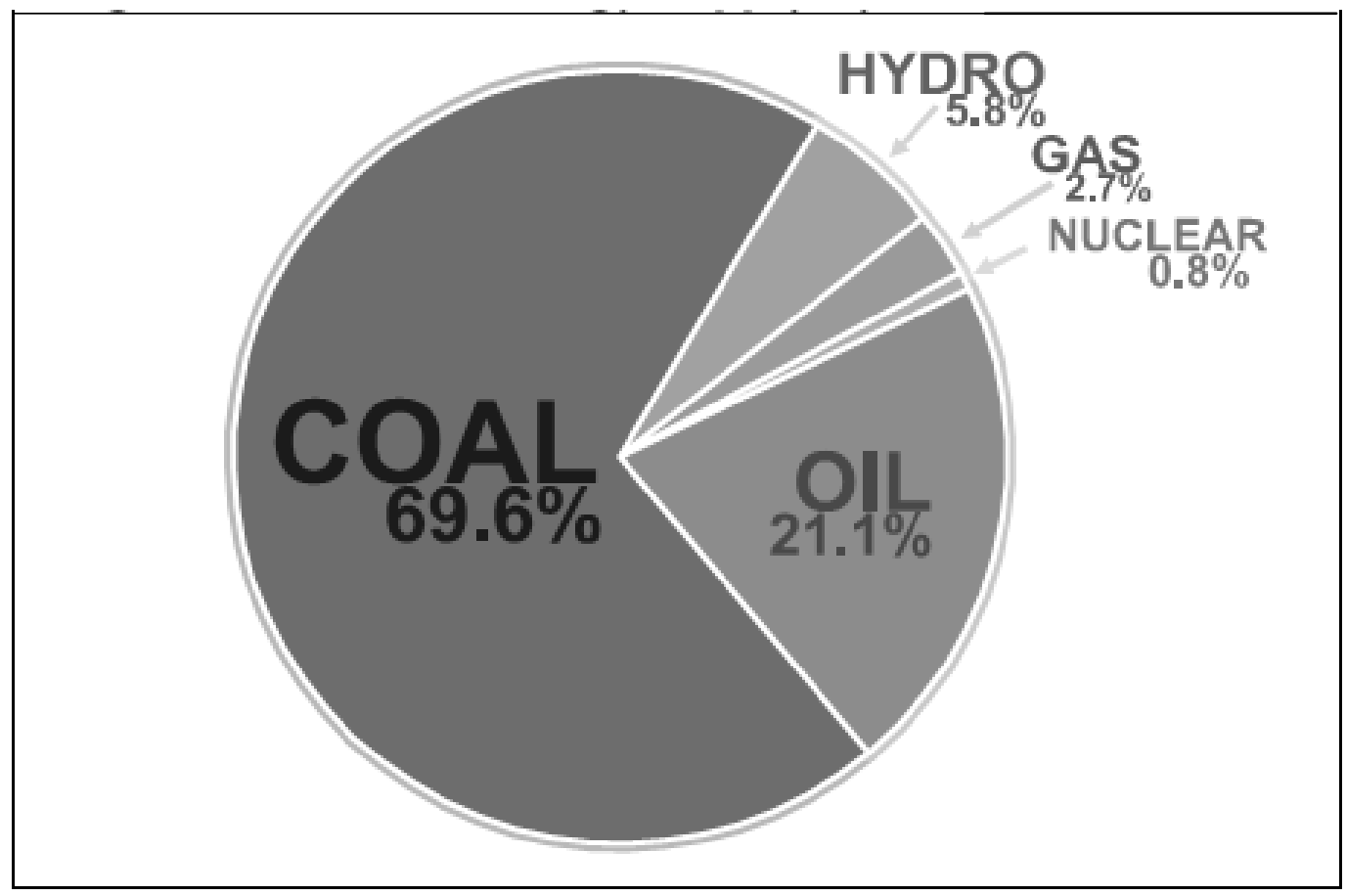

Source: Rosen and Houser, 2007, figure 16.

Figure 2. China's Energy Supply by Fuel, 2005

China is the world's largest producer and consumer of coal in the world (BP, 2010). China consumed an estimated 2.7 billion tons of coal in 2008, representing roughly 45 percent of the world total and a 129 percent increase since 2000 (DOE, 2009; World Coal Institute, 2009). In spite of massive demand China has traditionally been self-sufficient in coal, with 2009 the first year on record in which China was a net coal importer $(\mathrm{Yu}, 2010)$. Although total coal demand is projected to grow to between 3.81 billion and 4.26 billion tons in 2025 , China will still be relying on coal for over half of its energy consumption in 2030. China's massive coal endowment leaves it well positioned to use domestic production to meet growth in demand, with net coal imports projected to remain small in 2030 (IEA, 2007, 342). Putting aside the environmental problems 
associated with coal, having enormous coal reserves is a boon for China's economy and energy security as it allows China to meet its energy demand without being overly dependent on energy imports or subject to energy market price fluctuations.

China's oil sector, however, is facing a completely different situation. Demand is growing rapidly and domestic production, already relatively small, has nearly peaked and will soon start declining. In 2006, China produced 3.7 million barrels per day (mbd) of oil, and production is expected to level off at about $3.9 \mathrm{mbd}$ in 2012. Production is then projected to enter a long period of gradual decline to $2.7 \mathrm{mbd}$ in 2030 (IEA, 2007, 320). This decline has enormous implications for China's energy security as China is already the third-largest net oil importer in the world, behind the United States and Japan, and domestic demand will continue growing well into the future (DOE, 2009).

\subsection{China’s Energy Security Dilemma}

China's main source of energy insecurity is its growing dependence on imported oil. During the 1950s, China met its growing demand by importing oil from the Soviet Union and relying on Soviet technological assistance to develop its domestic oil industry (Zha, 2005, 39). In 1960, China opened the Daqing oilfield and by 1963 was producing over 88,000 bpd, allowing it to claim energy self-sufficiency. Increases in domestic oil production enabled China not only to keep up with its own growth in oil consumption, which had reached $1.77 \mathrm{mbd}$ in 1980 , but to export oil as well. China became Asia's largest oil exporter in 1983, and by the mid-1980s, was the sixth largest producer of 
crude oil in the world (Ebel, 2005, 7-9). This situation changed dramatically in the 1990s as domestic economic growth drove increasing demand for energy and oil in particular. China became a net oil importer in 1993 and between 1990 and 2006 oil demand grew from $2.4 \mathrm{mb} / \mathrm{d}$ to $7.2 \mathrm{mb} / \mathrm{d}$ in 2006 (Rosen and Houser, 2007, 19). The gap between domestic oil production and demand continues to grow; demand reached 7.8 million bpd in 2008, with imports growing to approximately 3.0 million bpd (DOE, 2009). Although projections about the future vary, most foresee China importing over two-thirds of its oil needs by 2030. The International Energy Agency (IEA) in 2007 projected that China's oil demand would grow to $16.5 \mathrm{mb} / \mathrm{d}$ by 2030 , with oil-import dependence growing to 13.1 mb/d (or approximately 79 percent dependency on oil imports) (Figure 3) (2007, 288). Meanwhile, the Asian Development Bank projects that China's "net oil import dependency is projected to increase to $71.9 \%$ in 2030 " $(2009,149)$. 


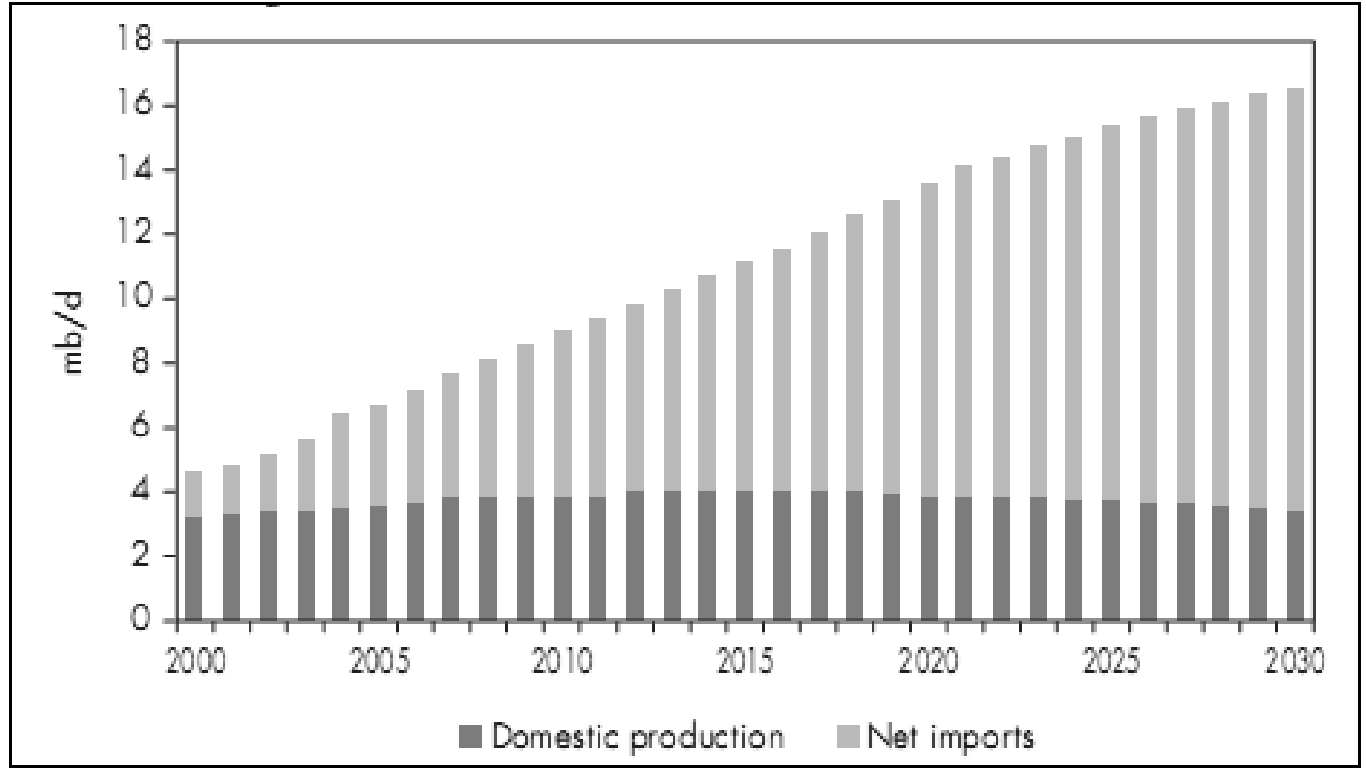

Source: IEA, 2007, figure 10.6.

Figure 3. China's Oil Balance in the IEA 2007 World Energy Outlook Reference

Scenario

According to Zha Daojiong, Director of the Center for International Energy

Security in China, despite some variations between estimates and projections, there is convergence on one conclusion:

no matter how China plans and carries out its energy policies, dependence on imported oil will have to continue. There is also convergence over the view that domestic oil production will stagnate. China therefore will have no choice but to rely on imported oil accounting for a growing proportion in its total oil consumption to satisfy the demands of its economic development. $(2005,42)$

Under these changing conditions, the term "energy security" has taken on new meaning and political salience for policy makers in Beijing. According to Erica Downs of the Brookings Institution: 
China's shift to a net importer of oil in 1993 introduced the term "energy security" to Chinese discourse on energy. It was not until 2000, however, when China's oil imports doubled and the bill tripled, that energy security became a common theme of public discourse. A search of the "China Economic News" library of China Infobank, a database of Chinese periodicals, reveals the term "energy security" appeared in only forty-one publications from 1994 through 1999, but in 1,150 publications from 2000 through 2005.(2006)

The dramatic rise of oil prices between 2001 and 2008 underscores the problems posed by reliance on imported oil in China. However, because oil is not easily substituted for, the government has few good options for how to resolve the problem. But before addressing China's pursuit of energy security, and the potential role of coal to oil in this pursuit, it is important to clarify the meaning of "energy security" and define the term in a Chinese context.

\subsection{The Meaning of Energy Security in China}

Oil, refined into liquid fuels, is an essential ingredient for economic growth and currently remains the most cost-effective and efficient fuel choice (as gasoline, diesel, or jet fuel) for transportation. Because of oil's critical importance to daily economic functions, countries heavily reliant on oil imports are often faced with a stark choice: either rely completely on international oil markets and associated risks such as potential economic disruption as a result to supply shortages or price shocks, or expend considerable political and monetary capital (usually in the form of national defense capabilities) to ensure the steady flow of oil to in order to meet national needs. China, because of its growing dependence on foreign oil, is now grappling with the same energy 
security vulnerabilities facing most other oil-import dependent countries; for the Chinese Communist Party (CCP), the stakes are arguably higher than they are for the leaders of democratic countries, given the role the Party plays in managing the economy and the extent to which its legitimacy rests on sustaining economic growth.

According to Daniel Yergin, Chariman of Cambridge Energy Research Associates (CERA), the goal of energy security "is to assure adequate, reliable supplies of energy at reasonable prices and in ways that do not jeopardize major national values and objectives"(1988, 11). Put simply, energy security means access to adequate, affordable, reliable supplies of energy. For geographically large countries endowed with abundant energy reserves, such as China and the United States, basic energy security has less to do with international relations and more to do with domestic energy policies, energy infrastructure development, and effective resource management, which is to say the first task of government is to harness domestic resources to provide adequate, reliable energy to its citizens. The most fundamental form of energy security, and the one most responsible for improving standards of living, is simple access to energy (usually in the form of electricity). China is over ninety percent self-sufficient in energy; in comparison, the US is over seventy percent self-sufficient (Yergin, 2007). Both countries are approaching electrification rates of 100 percent. However, these types of statistics are misleading because it is not energy per se that is a source of insecurity. For most countries, oil is the reason why security is a major factor influencing how economies conduct their foreign policies and international relations. In many respects, oil supply security has become synonymous with energy security. 
In China, energy security can be defined as "the acquisition of sufficient energy supplies to protect the Chinese leadership's core objectives at prices that are neither too high nor too low to undermine those objectives. Reliability, for oil and natural gas, includes the safe delivery of imports to China" (Downs, 2006, 13). The CCP's highest priority is staying in power, and factors that will determine its ability to stay in power include "ensuring domestic order and development, which are critical to the preservation of the power and legitimacy of the Communist Party; defending China against foreign threats to both territory and sovereignty; and attaining high levels of international power and prestige" (Swaine, 2008, 75). All of these issues, to a greater or lesser extent, would be affected by a disruption to China's oil import supply, making reliable access to oil of critical importance.

Countries reliant on imported oil have good reason to be concerned about oil supply security. Some of those concerns include that the region supplying the highest percentage of the world's oil, the Middle East, is chronically on the verge of war or instability; there is a strong likelihood that world oil production is nearing or has reached its peak, even as demand continues growing; and oil prices have recently rose from $\$ 20$ per barrel at the end of the 1990s to almost $\$ 150$ per barrel in 2008 and are currently (Summer 2010) hovering around $\$ 70$ per barrel. For China, distrust of the U.S. makes China's growing reliance on imports all the more alarming. Many in China subscribe to the theory that global oil production has peaked, or that at least it will not increase dramatically in the coming years, and they therefore worry about the ability of global oil production to keep pace with growing demand. How this concern relates to U.S.-China 
relations was articulated by Professor Shen Dingli of Fudan University when he asked "If world oil stocks were exceeded by growth, who will provide energy to China? America would protect its own energy supply. The U.S. is China's major competitor" (Goodman, 2005). Others point out that China's

distrust of energy markets is aggravated by the perception that these markets are dominated by the United States, a perception that overlaps with concerns that the United States is out to exploit China's energy weakness. Based upon strategic dominance in the Persian Gulf, the US Navy's control over critical energy transport sea lanes, and enormous power in the global oil industry and institutions, many (in China) believe the United States exerts a powerful influence on global oil prices and flow. (Lieberthal and Herberg, 2006, 16)

For China's leadership, perhaps no oil supply vulnerability is more disconcerting than U.S. control of global sea lanes of communication, and energy security concerns are thought to be a major driver of the People's Liberation Army-Navy's (PLAN) modernization efforts (Cole, 2006, 8). "At present, China lacks the naval power necessary to protect its sea lanes of communication. Beijing fears that during a national security crisis ships carrying energy resources could be interdicted by hostile naval forces. Any disruption to the free flow of energy resources into China could derail the economic growth on which the Chinese government depends to shore up its legitimacy and pursue its great power ambitions" (Storey, 2006). This worry is especially salient in the Strait of Malacca, through which over four-fifths of China's oil imports pass. These concerns over oil-import security, coupled with the financial burden of having to buy vast quantities of oil on the international market, have driven the Chinese government to take a host of measures aimed at enhancing energy and oil security and minimizing their exposure to disruptions in international oil flows. 
2.5 China's Response to its Energy Security Dilemma and the Role of Alternative Fuels

China's attempts to ameliorate its energy security dilemma include both domestic and international efforts. The international components of China's energy security strategy include, among others, developing a blue water navy, constructing pipelines to connect China with the energy exporting countries on its periphery, and investing in oil reserves abroad. These activities and their geopolitical implications have been discussed at great lengths by others and will not be reviewed here. China is also taking significant steps domestically to minimize the energy security risks associated with oil-import dependence. These include improving fuel efficiency by setting high miles per gallon standards for automobiles; incorporating natural gas into the public transportation sector; promoting energy conservation; investing in public transportation; incentivizing the development of electric automobiles; building a strategic petroleum reserve; and, most relevant to this study, developing alternative fuels. Given that China will inevitably be reliant on liquid transportation fuels for many years to come, the development of alternative fuels is an important component of China's energy security strategy.

There are many different definitions "alternative fuels." The Environmental Protection Agency's website defines alternative fuels as "Substitutes for traditional liquid, oil-derived motor vehicle fuels like gasoline and diesel. Includes mixtures of alcoholbased fuels with gasoline, methanol, ethanol, compressed natural gas, and others." The U.S. Department of Energy's definition includes not only the fuels traditionally thought of as alternatives to gasoline and diesel, such as biodiesel, hydrogen, and ethanol, but also 
fuels that create gasoline and diesel through alternative processes. In China, the definition of alternative fuels simply means those liquid fuel products which can substitute for oil, specifically those derived from coal and biomass ( $\mathrm{Hu}, 2007)$. Because alternative fuels may help ease China's oil import burden, the development of alternative fuels has been named as a priority in a number of government reports and proclamations (iCET, 2008).

Understanding the differences among different alternative fuels, and the feedstock used to produce them, is a science in itself. For example, the feedstock used to produce alternative transportation fuels include biomass, coal, and natural gas, and the end products can take many forms, including methanol, ethanol, biodiesel, dimethyl ether (DME), liquefied petroleum gas (LPG), and diesel (World Coal Institute, 2006). In this study the focus will be on the synthetic oil made from coal.

\subsection{Defining Coal to Oil and Imposing Limitations on the Scope of This Study}

The term "coal to liquids" is vague and does not make clear what type of liquid product is actually produced. The DOE defines coal to liquids as the processes of converting coal from a solid state into a range of fuels and chemicals, including transportation fuels such as gasoline, diesel, and methanol. These "liquid" fuel products and chemicals can be used as heating fuel, supplements to or alternatives for traditional transportation fuels (such as methanol and DME), traditional transportation fuels themselves (gasoline and diesel), and petrochemical feedstock. In the United States coal to liquids is understood to mean the conversion of coal into liquid fuels, but in China the terminology is different, reflecting the diversity of uses for coal as a feedstock in 
industrial processes. While there is a general term in Chinese for "coal to liquids"(mei ye hua), it is seldom used; more descriptive terms are generally favored.

In China, coal conversion processes are first broken into two categories:

traditional and modern, both of which include liquids as some of the resulting end products. Using Chinese definitions, traditional coal conversion processes yield the end products of synthetic ammonia, methanol, coke, and calcium carbide. Modern coal conversion processes generally result in synthetic oil products, olefins, DME, natural gas, and ethylene (NDRC, 2009). There are specific terms used to describe each end product, such as coal to olefins (mei zhi xiting), coal to dimethyl ether (mei zhi erjiami), or coal to natural gas (mei zhi tianranqi). For the purposes of this study I am using the term "coal to oil" (meizhiyou) to describe the process of converting coal into synthetic oil for later upgrading into gasoline, diesel, or jet fuel. However, to avoid confusion, I will not abbreviate the term CTO as this is the abbreviation used for coal to olefins, and I will instead write out the term in full.

Limiting the scope of the study to coal to synthetic oil is necessary given the scale of the industry and the complexity of the topic. But focusing only on coal to oil has important drawbacks that will significantly limit this study as it excludes other liquid fuels made from coal and ignores the extent to which coal can be used as a substitute for oil in other industrial processes. Many of the conversion plants making gasoline and diesel from coal also make other products that can be used either as a heating, cooking, or transportation fuel. While some of these end products may be used as transportation fuels, they might also be used for purposes that are completely different from oil use, in which 
case they do not directly contribute to China's energy security by replacing imports or increasing domestic production of "oil." Not only is it difficult to determine the approximate output of products other than synthetic oil at a given plant, it would be nearly impossible to trace the end use of the different products to determine how they are used.

By focusing on gasoline and diesel made from synthetic oil I can be certain that these products are contributing to China's energy security. At the same time, I am also overlooking the production of other coal-based fuels that may also be used in ways similar to synthetic oil. An example of this problem is methanol. China is already producing large quantities of methanol, made from both natural gas and coal. Methanol made from coal can be blended with gasoline and then used in automobiles as a transportation fuel, or it can be converted into ethylene or propylene for use in the petrochemical sector. Without highly detailed information, it is difficult to know how the methanol is made (i.e. from coal or natural gas) or how the methanol is being used. Discounting methanol and other products makes my study manageable, but it overlooks the important role other coal conversion processes might play in boosting China's production of liquid fuels.

Similarly, the conversion of coal into industrial feedstock, such as those needed by the petrochemical industry, is in itself an oil substitution strategy. As the name would suggest, the feedstock for the petrochemical industry has traditionally been petroleum. In China, the chemicals and petrochemicals sector produces such products as ammonia, methanol and various petrochemicals, including ethylene, and is the third-largest 
industrial energy consumer in China (IEA, 2007, 295). At the same time, the chemical and petrochemical sectors accounts for a majority of the oil consumed by industry, which is 32 percent of total oil consumption (Guth and Ginsberg, 2004). Thus, using coal conversion processes to create petrochemical feedstock can enhance China's energy security by meeting the "petroleum" demand of the petrochemical industry with domestic coal resources. All of this is to say that by focusing exclusively on coal to oil I am looking at the subsector of coal to liquids that will make the most direct contributions to China's energy security, while choosing not to analyze the extent to which "coal to liquids" in general can reduce China's import dependency or increase domestic production.

Finally, many coal conversion processes are similar in terms of water consumption, coal consumption, and greenhouse gas emissions. By excluding all forms of coal conversion except coal to synthetic oil from my analysis, I am will not examine how China's larger coal to liquids and oil-replacement strategy will affect China's environment and resource base, even though this is an important subject worth examination. China's coal to liquids industry is enormous and coal to oil is but a small part. But given the potential size of the coal to oil industry in China and the potential impact of this industry on China's environment, this study will contribute to understanding the difficult decisions confronting China's policymakers as they balance resource and environmental challenges with their pursuit of energy security. 


\subsection{History and Processes of Coal to Oil}

Coal to oil is not a new industry or new industrial process. Coal to oil was first used by the Germans during World War II as a response to Allied embargo of Germany's oil supply. Germany's industrialization of the process was so successful that more than 92 percent of Germany's aviation fuel and half its total petroleum needs during World War II were met by synthetic fuel plants. At its peak in early 1944, the German coal to oil effort produced more than 124,000 barrels per day from 25 plants (DOE website). An oil embargo drove Japan, too, to experiment with coal to oil during WWII, specifically in Northeast China (or Manchuria), but with much less success. Even the United States, facing oil shortages during the war, passed the Synthetic Liquid Fuels Act in 1944, which provided $\$ 30$ million for a five-year effort to produce synthetic liquid fuels from coal and other organic material (DOE website). But abundant, cheap oil following the war dampened interest in the coal to oil industry, and although several development programs remained in operation in the U.S. and other countries, South Africa has been the only country to commercialize coal to oil in the post-WWII era.

Beginning in the 1950s, South Africa began subsidizing coal to oil development, partially out of fear that its oil imports might be sanctioned because of its apartheid policy. In total, Sasol (South Africa's flagship energy and chemicals company) has over 50 years of experience converting coal to synthetic oil and today South Africa derives over 40 percent of its gasoline consumption from liquefied coal (Gibson, 2007). Following the oil shocks of the 1970s, coal to oil development projects were initiated with renewed interest in the U.S., Japan, and other countries heavily dependent on oil 
imports, but again the availability of abundant, cheap oil made large-scale coal to oil projects uncompetitive and unattractive. It has only been the past ten years, as oil prices and global energy demand began to surge, that coal to oil has reentered the global energy dialogue.

\subsection{Coal to Oil Processes: Direct and Indirect}

There are two main types of coal to oil processes, known as direct and indirect, with the latter being the most common. The indirect coal to oil process begins with coal gasification, which involves reacting coal with steam and oxygen at elevated temperatures and moderate pressures to produce a mixture of hydrogen, carbon monoxide, and carbon dioxide. After leaving the gasifier, the gas contains carbon dioxide and other impurities. Once impurities such as sulfur and mercury have been removed, and excess carbon dioxide is released into the atmosphere (in the absence of carbon capture and storage), the remaining mixture of hydrogen and carbon monoxide is known as synthesis gas, or syngas. The syngas is then sent through a process known as Fischer-Tropsch synthesis, where it is catalytically converted to a mixture of hydrocarbons. This mixture generally includes hydrocarbon gases similar to those found in gasoline, diesel, and jet

fuel, as well as heavier compounds that are categorized as waxes. After further treatment, the end result is retail-ready diesel fuel (or a combination of diesel fuel and jet fuel) and naphtha. The naphtha can be upgraded into gasoline, or it can be converted to ethylene and related chemical feedstock (Bartis et al. 2008). 
In the direct liquefaction process, a slurry comprising finely ground coal and a solvent is heated to temperatures above 400 degrees Celsius in a pressurized vessel containing hydrogen and an appropriate catalyst. The coal is converted into a liquid, separation and further conversion takes place, and the end result is synthetic crude oil. Through distillation naphtha and middle distillates are recovered, which can then be upgraded into gasoline, diesel, or various chemical products (Williams and Larson, 2003).

Through both of these processes coal is converted into products typically made from petroleum, which enables coal to substitute for petroleum in the industrial value chain. While economic issues, not technological barriers, are the main reason coal to liquids is not in greater use today, there are important resource and environmental issues associated with the coal to liquids process.

\subsection{Coal to Oil Resource Impacts and Economics}

The following sections outline the impact of coal to oil processes in terms of coal consumption, water consumption, and greenhouse gas emissions, and provides an overview of the economics of coal to oil projects.

\subsubsection{Coal Consumption}

Coal to oil is a large and inefficient user of coal resources. It takes approximately 3.5-5.0 tons of coal to produce one ton of liquefied product regardless of which method (direct or indirect) is used. Developing a large-scale coal to oil industry thus has significant implications for the coal industry and coal resources (and by extension the 
environment) for any country seeking to bring this industry to scale. The result is that for countries without abundant coal resources, coal to oil not an attractive strategy. Japan, which does not have significant coal reserves, determined in the 1980s that using coal to oil as an oil replacement strategy would only shift Japanese dependence on imports from oil to coal. Alternatively, for countries rich in coal resources, such as the U.S., China, Australia, and South Africa, coal to oil is potentially viable as a means of increasing reliance on domestic, rather than imported, oil production. But regardless of the country or the size of its coal resources, the sheer volume of coal consumed by a large-scale coal to liquids industry would have a dramatic impact on the domestic coal sector (Bartis et al. 2006, 6).

\subsubsection{Water Consumption}

The process of converting coal into gasoline, diesel, or any other liquid fuel consumes large quantities of water. As one source explains,

Water is a vital part of the process, either as hot steam or as a feedstock for hydrogen production. Water for cooling and the boiler must also be provided, and for a larger plant the amount of water consumed can be very large indeed. Water consumption is approximately equivalent for DCL and ICL... Therefore, water availability is an essential factor to be considered during placement of CTLfacilities. (Höök and Aleklett, 2009, 8)

There are many factors that determine the exact volume of water consumed per ton of liquid fuel produced, including the design of the plant, the type of technology used, the quality of the coal consumed, and the humidity and temperature conditions at the plant location (DOE/NETL, 2006, 20). The numerous variables involved lead to different estimates for the water to product ratio, with the range generally falling between 5-10 
tons of water consumed per ton of liquid fuel produced (NETL, 2003, 20; IEA, 2007, 357;

Nolan). For the purposes of this study, I will use the figures most often quoted in reference to China's CTL industry, which is approximately 8-10 tons of water consumed per ton of product produced.

\subsubsection{Greenhouse Gas Emissions}

The coal to oil process produces large volumes of carbon dioxide. Experts agree that "Examining the entire fuel cycle, producing and using diesel fuel and gasoline derived from coal will yield much higher greenhouse-gas emissions than producing and using fuel derived from conventional petroleum" (Bartis et al. 2008, 31). Various studies have shown that without carbon capture and storage (CCS), coal to oil's mine-to-wheels greenhouse gas emissions would be 2.0 to 2.2 times higher than the well-to-wheels emissions associated with fuels produced through the refining of conventional light crude oils (Figure 4) (Bartis et al. 2008, 31; Hawkins, 2006, 4). Carbon dioxide is released at both the coal to oil production plant and from the exhausts of the vehicles that burn the fuel. In the indirect method, $\mathrm{CO} 2$ is released during the snygas preparation process, while in the direct method coal gasification is used to produce hydrogen and the $\mathrm{CO} 2$ is vented into the atmosphere. The use of CCS can remove most of the $\mathrm{CO} 2$ produced during the coal conversion process, but $\mathrm{CO} 2$ is still released during the combustion of the liquid fuel, making the $\mathrm{CO} 2$ emissions roughly equivalent to traditional petroleum in a well-towheels analysis. 


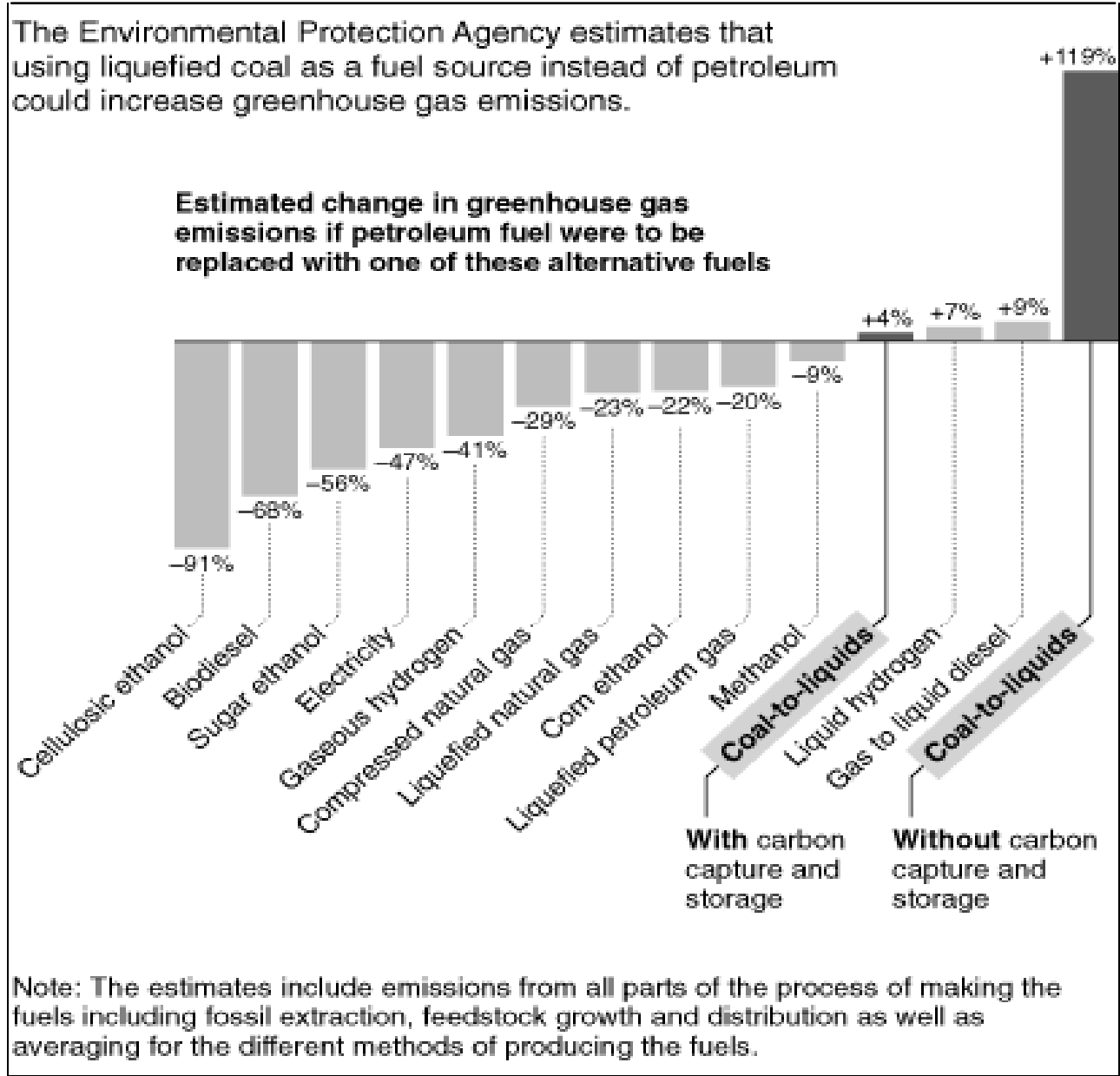

Source: Environmental Protection Agency

Figure 4. Comparing the Greenhouse Gas Emissions of Different Fuels

\subsubsection{Economics}

While energy security concerns provide an incentive for governments to consider developing coal to oil, the primary reason energy companies and coal-producing states have become interested in coal to oil in the first decade of the $21^{\text {st }}$ century is the pursuit of profit. Soaring international energy prices and a growing recognition that global oil production might not be able to meet demand growth indefinitely has led many to view 
coal to oil as a potentially lucrative industry. With the days of $\$ 15-20$ barrels of oil gone forever, and demand for oil still growing, many kinds of energy that were once viewed as too expensive are being reconsidered. Ultimately, the same factor that prevented coal to oil's large scale development over the past fifty years - oil prices - is now driving energy and coal companies to look anew at coal to oil.

The profitability of coal to oil projects is determined by comparing the cost of producing a barrel of synthetic oil from coal with the price of a barrel of oil on international markets, which can be summarized as follows:

If [coal to oil] production costs, including a reasonable rate of return on capital investments, are below the prevailing market price for oil, a domestic CTL industry will generate economic profits. For example, if CTL production in 2030 costs an average of $\$ 40$ per barrel and world crude prices are between EIA 2007 reference-case and high-oil-price levels, the economic profits of a three million bpd domestic CTL industry would range from $\$ 20$ billion to $\$ 70$ billion per year (in 2007 dollars). (Bartis et al. 2008, 60)

Estimates vary on the exact price point at which coal to oil becomes profitable because of the large upfront investment costs of building a plant and the price volatility of other inputs such as steel for construction, the cost of coal, and labor. In general, costs in China are estimated to be much lower than in countries like the U.S. or Australia because of inexpensive coal and lower construction and operating costs. According to one 2007 report

It has been estimated that, using current processes, the threshold of profitability for USD 20/ton coal may be reached for a crude price of about USD 70/bbl, a figure that has been largely exceeded on the spot market in 2007. The cost of USD 20/ton of coal is attained at top- performing mines, but it remains well below international prices. That's why, initially, projects like this will only be of 
interest to countries that not only possess coal resources in abundance but are also seeing high domestic demand for liquid motor fuels. (Marion, 2007, 4)

In China the break-even point for coal to oil profitability is thought to be lower. $\mathrm{Li}$ Yongwang, chief scientist of the coal to oil task force of the Shanxi Coal Chemical Research Institute, estimated in 2009 that "Based on current coal prices, the costs of an indirect coal to oil plant would be about $\$ 50$ dollars per barrel. Larger production scales and better technology could, in time, help reduce the volume of coal needed. In that case, the cost might fall closer to 40 U.S. dollars per barrel” (Xinhua, 2009). Zhang Yuzhuo, CEO of China's Shenhua Group, has estimated that his company's production cost of synthetic crude is less than $\$ 40$ dollars per barrel (CCTV, 2009). Overall, most experts in China agree with the estimate of needing an international oil price of between $\$ 40-50$ per barrel for coal to oil to be profitable in China. However, the enormous capital costs of building a coal to oil project, coupled with the long construction times, makes it difficult for companies other than Sasol of South Africa to be certain about the exact profit point, and much also depends on the type of government support and the terms of financing the projects receive.

\subsection{Geographical Prerequisites for Building a Coal to Oil Plant}

The resource and environmental needs of the coal to oil process impose limitations on which countries are reasonably able to pursue such projects and where plants can be located within countries. In general, countries might choose to pursue coal to liquids for one of two reasons. The first is to improve energy security by using the coal 
to oil process to increase the domestic production of synthetic oil products and ease dependence on imports. The economics of production is a second potential factor, one that is related to high oil prices which, correspondingly, make coal to oil projects a profitable alternative to creating liquid fuels from petroleum. For countries without large domestic coal reserves, pursuing coal to oil makes little sense on either account; the coal consumed by the coal to oil industry would either have to be imported or would have to be shifted away from other domestic uses, and the cost of importing coal would likely make coal to oil uneconomical. For this reason, the only countries that have seriously considered or utilized coal to oil in recent years are the United States, China, India, Australia, South Africa, Indonesia, and Germany - all countries with abundant or relatively large coal reserves (World Coal Institute, 2006).

For countries that choose to pursue coal to oil, the geographic distribution of domestic water and coal resources within the country largely determines where coal to oil plants can be built. In general, a coal to oil plant must be located in a setting that meets two conditions: at or close to a mine that produces large quantities of coal; and in close proximity to a reliable water source (Gibson, 2007). In the case of the former factor, the mine location, the price of coal is lower thereby avoiding the high costs of transportation and the tight profit margins associated with coal to oil projects. In term of proximity to water sources, the large volumes of water consumed by coal to oil plants make it imperative that the plants have reliable access to affordable, year round water supplies. 


\subsection{Why CTL is an attractive strategy for China}

The makeup of China's resource endowment, its growing demand for liquid transportation fuels, and the goal of minimizing reliance on imported oil have combined to make coal to oil an attractive strategy. Against this backdrop, and with the resource conditions in place to exploit coal to oil technology, two developments over the past ten years have accelerated China's pursuit of coal to oil.

The first factor was the realization by the central government of just how dependent China was becoming on imported oil. As recently as 2000, China imported less than a quarter of its oil consumption and few at that time foresaw the economic boom China was about to enter. But by 2005 , as the economy grew by close to ten percent and oil demand accelerated rapidly, China's leadership increasingly came to recognize how dependent it had become on foreign oil and the transportation routes upon which imports depended. As a result, China began taking more concrete steps to manage demand, to secure resources abroad, and to develop alternative fuels at home.

The second factor was the precipitous rise in international oil prices. Between 2000 and 2008, oil prices rose from a low of \$23 per barrel to a high of \$145 (DOE, 2009). Because of the nature of energy pricing in China, where fuel and electricity prices are controlled and set artificially low by the National Development and Reform Commission, the rise in energy prices created an enormous challenges for the government as it attempted to meet growing demand, keep energy affordable domestically, and manage conflicts of interest created by the disparity between domestic and international prices. An article in the Shanghai Daily in 2008 described the problem 
succinctly, "A renewed fuel shortage has hit many Chinese cities over the past weeks, as independent refiners cut output to narrow their losses from the government's cap on pump prices. This may pressure the government to reconsider its fuel price-setting policy, which is designed to tame inflation and shield low-income groups. Short supplies during the peak summer season may also spark social unrest."

Were China able to boost domestic oil production, it would alleviate at least some of the financial pressures created by buying high-priced oil on international markets. As one energy expert in China, coal to liquids will "offer an efficient way to quench China's thirst for energy. It is conducive to reducing China's external dependence on crude oil" (Xinhua, 2006). 


\section{Chapter 3: Energy Policymaking in China: Three Core Challenges}

\subsection{Introduction}

Before examining the development of China's coal to oil industry and analyzing how the government has managed the industry, it is first necessary explore some of the characteristics of energy policymaking and energy resource management in China. The need to effectively manage scarce resources, support economic growth, enhance energy security, and account for the interplay between energy resource development and local conditions is not unique to the coal to oil industry. Rather, this challenge comes into play with a range of different energy issues as the government formulates energy policies that attempt to balance competing demands and priorities, account for the needs of different constituencies, while at the same time avoid sacrificing national priorities. In any system, there are invariably trade-offs involved, and many factors aside from resource endowments or energy demand inform energy and resource management policy decisions. Some of these tradeoffs have little to do with pure resource management per se, but involve balancing the demands of different actors or bureaucracies, and the process is often messier than meets the eye. This is especially the case in China, where by virtue of its size, political legacy, and breakneck growth, the inputs into the energy policymaking system are complex and hugely consequential. One of the goals of this study is provide an overview of that complexity by incorporating not only the resource and environmental challenges issues related to coal to oil development, but also the political, social, and economic factors influencing coal to oil policies. 
In this chapter I will review existing literature to explain the observations of scholars who have studied China's energy sector. My focus will be on three of the primary factors thought to influence and complicate energy policy in China. These three topics each have direct relevance to understanding how and why the coal to oil industry has developed in China, and the challenges confronting the government as it attempts to formulate policies to govern the industry.

\subsection{Fragmented and Weak Bureaucracies}

China's energy policies are not made or driven by a single bureaucratic institution that makes rational, calculated decisions about the direction of the energy sector. On the contrary, institutional weakness is one of the greatest impediments to China creating more effective energy policies. Since reform and opening in 1978, the institutions governing China's energy policies have been in a perpetual state of revision and reshuffling. Previous government agencies tasked with managing China's energy sector include the State Energy Commission (1980-82), the Ministry of Energy (1988-93); the National Development and Reform Commission's (NDRC) Energy Bureau (2003-08); the Energy Leading Group and State Energy Office (both established in 2005): the National Energy Administration (NEA) (established in 2008); and, most recently, the National Energy Commission (established in 2010). According to Erica Downs, "The formal bureaucratic organizations within the central government that comprise China's energy bureaucracy have been in a state of flux since the founding of the People's Republic as the Chinese government has repeatedly sought to create a more effective 
institutional structure to manage the country's growing demand for energy" $(2007,68)$. The lack of a strong, centralized energy institution has made governing China's energy sector and effectively managing energy resources an ongoing challenge.

Today, it is the NDRC and NEA (which is within NDRC) that are primarily responsible for setting energy policy. But their decisions often must be coordinated with or are in competition with the authority and interests of other ministries and agencies, including the Ministry of Land and Resources, the Ministry of Water Resources, the Ministry of Science and Technology, the State Electricity Regulatory Commission, the Ministry of Railways, and the State Environmental Protection Agency (Kong, 2005, 21; Meidan et al. 2009, 596). Although it is too early to assess the role of the NEC, this new agency is likely to be constrained by the same problems that have plagued past energy agencies, including a lack of political authority, an inability to balance the interests of competing stakeholders, and a lack of financial and human resources (Downs, 2007, 86; Downs, 2006, 20-22; Kong, 2006; Andrews-Speed, 2004). The result over the years has been an increasingly fragmented institutional structure of authority, difficulty formulating coherent policy, and competition with state-owned energy agencies for policy control (Andrews-Speed, 2004, 57).

Until 1979, China's energy sector had been organized as a vertically integrated, top-down, state-owned utility. Once economic growth became the overarching priority during the Deng Xiaoping era, authority over China's energy sector was delegated from an elite few into the hands of various ministries and provinces, giving rise to what Kenneth Lieberthal and Michael Oksenberg have dubbed "fragmented authoritarianism." 
Their 1988 study on policymaking in China, which focused on energy policy, "reveals a fragmented bureaucratic structure of authority, decision making in which consensus building is central, and a policy process that is protracted, disjointed, and incremental." Scholars over the years have echoed their findings, namely that the policy making process is arduous, that most policies are shaped over a long period of time, and that "the lack of a cohesive, consistent national energy development policy is quite evident" (Lieberthal and Oksenberg, 1988, 22-24).

According to Bo Kong, it is unclear who actually makes energy policy in China and the multiple layers in China's energy policymaking structure fragment and paralyze the process. Overall, he describes China's energy policies as "diffuse, overlapping, adhoc, and ill-coordinated" (Kong, 2005, 21-23). Edward Cunningham seconds this conclusion, finding that "government actors - even at the central level - are plagued with vague and conflicting interests resulting in stillborn energy institutions that historically have failed to produce focused energy policy" (Cunningham, 2007, 1). Phillip AndrewsSpeed identifies structural issues as at the root of China's energy policy-making problems, and concludes that the

weaknesses in China's current energy policy can be traced primarily to the structure of policy-making. The fragmented institutional structure of the energy industry is almost bound to lead to a fragmented energy policy. In the absence of a Ministry of Energy, policy is developed more by the aggregation of the specific industry objectives driven by the leaders of these industries than by the formulations of sector-wide initiatives. (Andrews-Speed, 2004, 75)

The MIT Future of Coal Report make a similar observation when discussing China's energy bureaucracy, stating: 
[the] responsibility for energy pricing, for the approval of infrastructure projects, for the oversight of state energy companies, and for long-term energy policy is spread across many agencies, most of them seriously understaffed, and some of which - given their very recent emergence on the scene - are notably weak in relation both to other agencies and to the players they are supposed to be regulating. (MIT, 2007, 64)

In sum, one of the greatest obstacles challenging China's energy governance is

the lack of a strong, well-funded ministry or department of energy that can contend, on even footing, with the numerous bureaucratic and private-sector stakeholders. The leading energy bureaucracy of any country invariably faces an array of problems; in China, the situation is made worse by a lack of authority, manpower, and expertise. Thus, one of the key factors to be evaluated in this case study of China's coal to oil industry is the extent to which the central government's energy institutions are able to formulate a coherent coal to oil policy that fits rationally within China's overall energy strategy. Has the government been able to formulate policy in a timely fashion that indicates control over the various interests and stakeholders involved, or is it reactive and creating policies ad hoc as developments on the ground proceed ahead of its control?

\subsection{Powerful Energy Companies}

A second key feature observed by those studying energy policy and energy resource management in China is the disproportionate influence of state-owned energy companies. While the energy institutions responsible for governing China's energy sector and formulating industry-wide energy policies are understaffed, often underfunded, and lack political authority, China's largest energy companies employ tens of thousands, have their own well-staffed energy research institutions, and often have direct access to the 
senior leadership in Beijing. This is largely the result of historical legacy as many of the large state-owned energy companies in China were once ministries themselves and held considerable sway over China's national energy and economic policies (Downs, 2006, 21). In the 1980s and 1990s, the government began eliminating special line ministries, such as those in charge of the coal and petroleum industries, and created state-owned energy companies in their place (Kong, 2006). This transition has affected China's energy governance in two important ways.

First, the newly-formed state-owned energy companies often took with them the entrenched organizational culture and expertise that had been developed over decades (Downs, 2007, 71-72; Kong, 2006, 73), with the result that while the government has undergone periodic reshuffling and reorganization, state-owned companies are among the most coherent entities in the energy sector. State-owned enterprises (SOEs) "are the organizations that are most capable of defining their own interests and that are most likely to act, making decisions that their ostensible state regulators and overseers can barely keep up with and sometimes do not even monitor" (Lester and Steinfeld, 2006, 23). The pull of higher salaries has also challenged the government's ability to retain highly qualified staff members, leading to a decline in talent within the government and an increase in lobbying power for the energy companies (Kong, 2006, 74).

Second, without a powerful Ministry of Energy with the same standing as other ministries or the energy companies, the powerful state-owned companies retain an advantage over the institutions attempting to govern them.

When the Chinese government began to restructure the country's ministries into corporations in the 1980s, the leaders of the companies fought to retain their bureaucratic 
ranks to retain their leverage over the policymaking process... They can contact China's leaders themselves rather than going through the energy bureaucracy, which increases their power relative to that of the country's energy institutions. (Shirk, 1993, 107-08).

With the government institutions responsible for overseeing large and diverse portfolios of responsibility, not to mention the task of interacting with foreign interlocutors, it is difficult for those in charge of energy policy to stay ahead of activities on the ground in China. The result is that government energy institutions, while nominally in charge of energy policy, must compete with much larger entities for access to the political leadership, intellectual capital, and influence over China's energy policies.

Powerful energy companies have also been known to pursue their own interests to the detriment of China's energy security, and their intransigence has at times created disruptions in the functioning of China's economy. Examples of problems or disruptions resulting from public-private energy conflicts include pricing disputes between power producers and coal companies that led to electricity shortages in 2008 (Xinhua, 2008); the government's inability consistently control or direct the activities of national oil companies abroad (Zha, 2010); and the illegal export of crude oil and pricing disputes between the government and national oil companies that resulted in fuel shortages in 2005 (Bradsher, 2005). Thus, state-owned energy companies not only exert influence over energy policy, but also sometimes disobey the policy directives of the central government if those policies conflict with their pursuit of profit or market share. 


\subsection{Challenges of Decentralization}

One of the keys to China's rapid economic development over the past thirty years has been economic and political decentralization. The planned economy had in the past been controlled by Beijing and an elite group of leaders, whereas reform and opening allowed the provinces to exert greater control over their economic destiny. The effectiveness of this reform and of market forces in general lifted hundreds of millions out of poverty. However, one consequence of decentralization has been the relinquishing of absolute authority over how the provinces developed economically, including the central government's absolute control over energy infrastructure development. As observed by Lieberthal and Oksenberg, "The formal organizational charts and the structure of authority suggests the top leaders are efficiently in command of the bureaucracies and the policy process. But at the provincial and local levels, the reality frequently diverges sharply from the policies proclaimed in Beijing, and orders from the center often are not scrupulously implemented in the provinces" $(1988,32)$.

Noncompliance and the failure of provinces or lower levels of government to implement policy are especially evident in China's energy sector. Case studies have repeatedly shown that there is a disconnect between the central government's policy pronouncements and the actual implementation of those policies at the provincial level.

Provincial governments are often unwilling to follow central government edicts when it conflicts with their own domestic economic policies, and they often use creative methods for circumventing central government policies. A prime example is the construction of illegal power plants. In 2005 the NDRC, under orders from Chinese 
Premier Wen Jiabao, issued a directive ordering local officials to clamp down on unauthorized power plants, the total amount of which was estimated to be between 120140 GW (Modern Power Systems, 2005, 5). As one article pointed out, the fact that these plants are illegal "means neither that the plants are hidden in a closet nor that they lack any governmental oversight. What it does mean is that they are not part of a coherent national policy, that they are frequently outside national standards, and that they often evade control even by their ostensible owner at the national corporate level" (Lester and Steinfeld, 2006, 7). The central government has also had difficulty controlling the number of small coal mines, the proliferation of biofuels plants, and the construction of golf courses. The MIT Future of Coal report sums up the situation, saying

the remarkably rapid growth of energy consumption in China has been possible because a host of infrastructural issues are being resolved very quickly by individuals and organizations operating well below the level of national energy corporations. Almost daily, actors at the grass roots level are making key decisions about China's physical and technological infrastructure - decisions with profound consequences for its long-term energy development. $(2007,63)$

As mentioned above, these developments do not take place beyond the purview of local authorities, but rather are hidden from the national government as provincial and municipal leaders pursue economic growth to advance their political careers or for economic gain. In short, the devolution of authority from the Center to the provinces over the past thirty years has weakened the traditional levers of authority exercised by Beijing, hampering the government's ability to control development in the provinces and manage the national energy sector. 


\section{Chapter 4: The Evolution of China's Coal to Oil Industry}

\subsection{Introduction}

In the following chapter, I will describe the evolution of China's coal to oil industry and the government's various attempts to manage or shape its development. By describing in detail both the industrial development of the industry and the government's specific policy statements and directives, the stage can be set for answering the questions driving this study.

\subsection{Early History of Coal to Oil Development in China}

China began developing its domestic coal to oil technologies in the 1980s with the establishment of a coal liquefaction laboratory within the China Coal Research Institute during the 6th Five Year Plan period (1981-1985). The laboratory was supported by the State Planning Commission, the Science and Technology Commission, and the Ministry of Coal Industry; over the following fifteen years the laboratory collaborated with foreign technology providers to conduct market studies in China of three DCL technologies (Sun, 2010, 14). By the mid-1990s coal to oil was gaining strategic significance due to China's new reliance on imported oil. According to the Zhang Yuzhuo of China's Shenhua Group (henceforth to be called Shenhua), the largest coal mining company and the driver of coal to oil development, "Thirty years ago, China had started research into CTL, learning from Japan, Germany and USA. A turning point came in 1993 when China became a net oil importer, resulting in a foreign currency deficit (unlike today). The government 
responded by using coal in place of fuel oil” (IEA, 2006, 31). A further turning point for coal to oil development came in 1998, when China's State Council gave Shenhua \$1.3 billion to develop a coal to oil project as part of a "coal replacing oil fund" (Sun, 2008).

China's first CTL project, however, was a failure. Launched in 1999 in Pingdingshan, Henan province, the project was designed with a 500,000 ton annual capacity, but the coal to be used proved unfit for liquefaction and the project was terminated shortly thereafter (Qi, 2006) (Figure 5 ). Coal to oil development was expanded and accelerated in 2001 when energy technologies were included in China's national 863 Program. The 863 program was originally started in 1986 to help China's civilian scientific research establishment catch up with modern advances in all fields of technology, and energy technologies were included in the 863 program in response to China's growing reliance on imported oil and the environmental impact of its heavy reliance on coal. Clean coal became a core focus of the 863 Program and increased levels of funding began flowing into research on coal gasification, coal to liquids, and other advanced clean coal technologies (Osnos, 2009). 


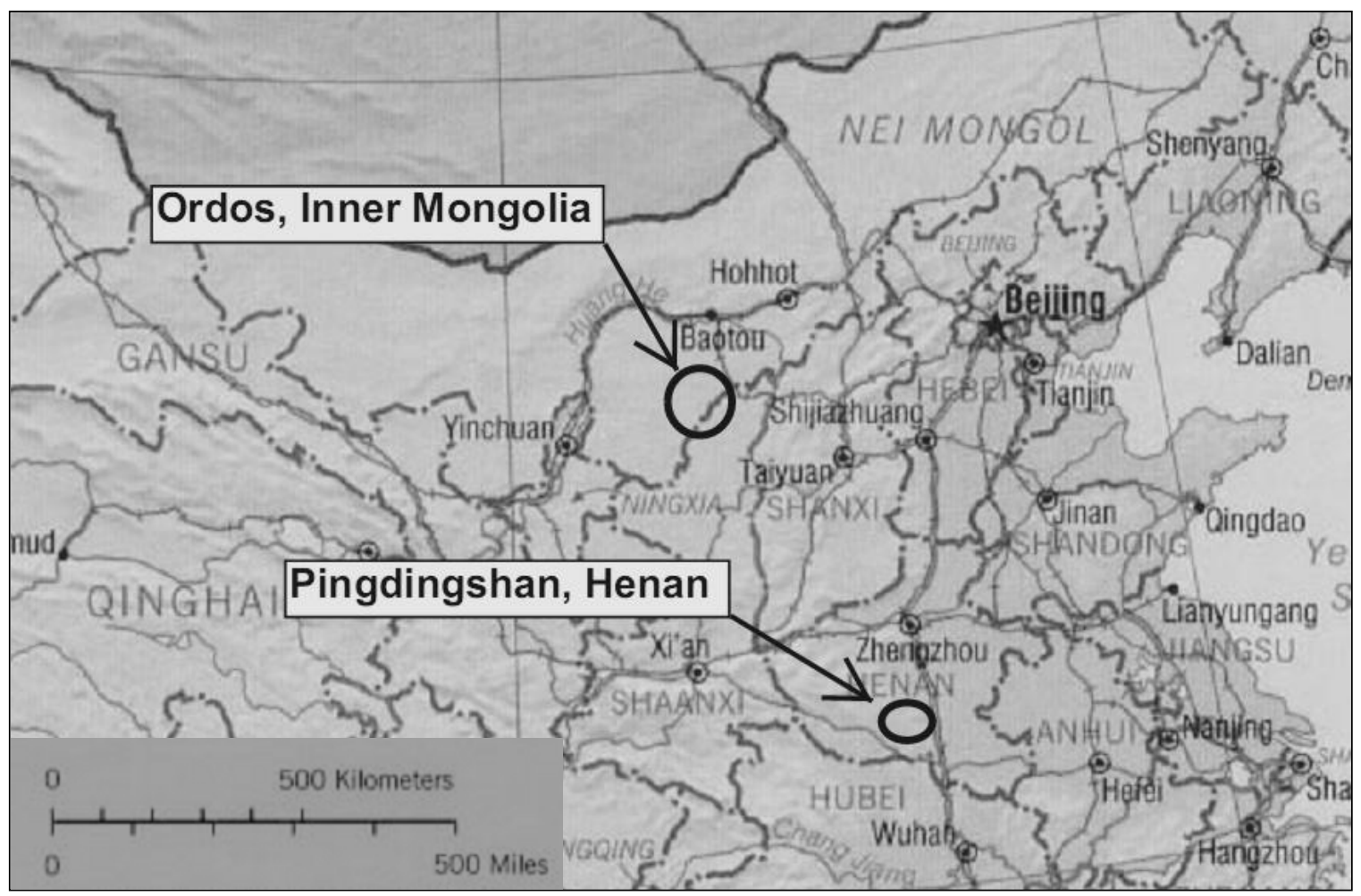

Figure 5. Approximate Location of Ordos, Inner Mongolia and Pingdingshan, Henan.

Following the problems at Pingdingshan, Shenhua took the lead in coal to oil development and completed a feasibility study on the construction of a large-scale direct CTL plant in 2002. In late 2003, construction of the plant began in Majiata of Ordos City, Inner Mongolia (Figure 5). By the time construction was underway, the price of a barrel of oil had risen to $\$ 37$ dollars in 2004, up from just $\$ 12$ in 1998, and China’s energy demand growth was exceeding nearly all previous expectations. These factors - rising energy prices and growing demand for oil - combined to accelerate government and private sector interest in coal to oil in China and to jump-start the industry. The period 
from 2004 to the present, during which most coal to oil development activity has taken place, is the focus of this study.

\subsection{The Evolution of China's Coal to Oil Industry and Policies}

After construction commenced on Shenhua's one million ton per annum coal to oil plant in Inner Mongolia, domestic and international coal mining and energy companies rushed to invest in an industry that looked set to boom. Sasol of South Africa was one of the first international companies to pursue coal to oil opportunities in China. Between February and June of 2004, Sasol met multiple times with representatives of the NDRC's indirect coal to oil working group in Beijing and South Africa. It was reported in 2004 that Sasol and Shenhua were considering entering into a 30 billion Renminbi (RMB) joint-venture to produce gasoline and diesel out of coal, and that Sasol would study the feasibility of developing two 3 million ton per annum (mta) plants to be located in Shaanxi and Ningxia (Madlala, 2004). In the summer of 2004, Royal Dutch Shell (henceforth called Shell) also began talks with the NDRC's working group on coal to oil, and soon it was announced that Shell would be cooperating with the Shenhua-Ningxia Coal Company (a subsidiary of Shenhua) to conduct a pre-feasibility study on the market, economics, technical solutions, regulations and possible sites for a proposed $3 \mathrm{mta}$ coal to oil plant. By all appearances, the central government appeared to fully support coal to oil development, and officials from the NDRC were endorsing coal to oil as part of China's overall plan to reduce the nation's reliance on crude oil (Lim and Ng, 2004). 
In 2005 and 2006 the rush to establish coal to oil plants in China continued gaining momentum, setting off wild speculation began about how much money China would invest in coal to oil and how many tons of liquefied coal would eventually be produced. Forbes reported in 2005 that China was planning to invest at least U.S. \$24 billion in coal to oil technology to cut its growing reliance on oil and gas imports (2005). Shenhua, too, was making bold estimates on how much transportation fuel would be produced from coal in the future, with a spokesman announcing in 2004 that Shenhua would produce 10 million tons per year of liquid fuel by 2010 and 20 million tons per year by 2020 (approximately 200k barrels per day (bpd) and 400k bpd respectively). According to a presentation by Shenhua CEO Zhang Yuzhuo at a 2006 IEA conference, "Shenhua's target in the next 5 years was four plants producing a little over 10 million tons of oil equivalent (MTOE) per annum; after that, another five projects were planned in the following 5-6 year period. He said many other companies had projects in planning that would proceed soon" (IEA, 2006, 24). Shenhua later increased its estimates to 30 mta by 2020, an amount that, based on 2006 estimates, would equal almost 15 percent of China's projected gasoline and diesel demand for that year (Wang, 2006). The rush to build projects was so strong that in 2006 "almost all coal-producing provinces - Inner Mongolia, Yunnan, Heilongjiang, Shaanxi, Shanxi, Shandong, Gansu, Guizhou, Anhui and Henan - have [had] CTL plans. One estimate says the total production capability of CTL plants that are currently under construction or ready to be kicked off could exceed the equivalent of 16 million tons of crude oil" (Qi, 2006). Coal to oil looked to be the wave of the future, and project announcements, production projections, and the apparent 
certainty with which those projections were made created the impression that large-scale coal to oil development was a foregone conclusion.

The size of the investments being considered by Sasol and Shell, the two primary foreign companies involved in the early stages of the coal to oil rush, was staggering. Sasol's feasibility studies on two join projects, with the Shenhua-Ningxia Coal Company (henceforth to be called Shenhua-Ningxia) at the Ningdong coal chemical base near Yinchuan, Ningxia and with Shenhua near Yulin, Shaanxi, had an estimated cost per project of US \$3-4 billion(Lim and Ng, 2004). The joint project Shell was studying with Shenhua, also at the Ningdong coal chemical base in Ningxia, called for investment of approximately \$5-6 billion (Figure 6) (Oil and Gas Journal, 2006).

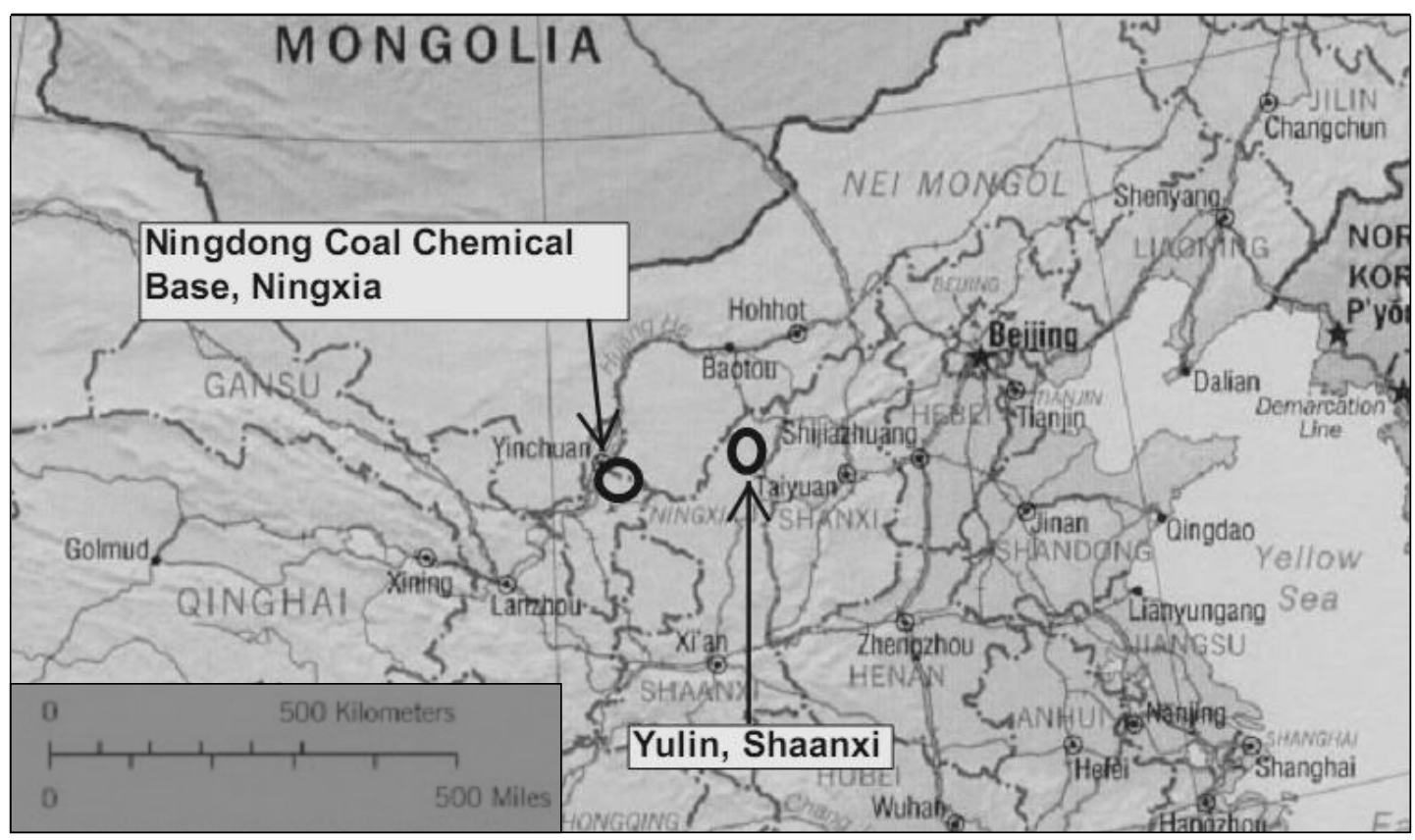

Figure 6. Approximate Location of the Ningdong Coal Chemical Base in Ningxia and Yulin, Shaanxi. 
Meanwhile, international energy companies were not alone in their pursuit of investment opportunities and market share. Domestic Chinese companies such as Yitai Group, Lu'an Group, Yankuang Group, Shandong Lueneng Mining, Xuzhuo Mining Group and others were also announcing large-scale coal to oil projects (Forbes, 2005).

The government's support of coal to oil development was on display in June 2006 when Chinese Premier Wen Jiabao visited the site of Shenhua's Inner Mongolia coal to oil project (Xinhua, 2007a), followed by a visit to the Sasol headquarters in South Africa the same month (Sasol, 2006). At the Shenhua plant Premier Wen called coal to oil "an important part of China's energy security strategy" and a "major scientific and technological experiment;" at the same time, he also stated that there should first be a pilot project and China should not "rush into action" (yi hong er qi) (Xiao, 2008, 111).

On July 7, 2006, the government made its first concrete policy statement on coal to oil as it took steps to cool down the investment rush. The NDRC's "Notice on Enhancing Management of Coal Chemical Projects and Promoting Healthy Development of the Industry" called for halting the development of all coal to liquids plants that would result in less than 3 million tons per annum of liquefied product and raised key concerns about the industry (concerns that would appear repeatedly in future announcements). While acknowledging the important role China's coal chemical industry could play in easing China's energy demand-supply contradiction by substituting coal for oil, the circular pointed out a number of problems associated with the rapid development of the industry, including the pressure coal chemical plants place on coal resources, the 
environment, and water resources, as well as acknowledging the technology- and capitalintensive nature of the industry (NDRC, 2006).

Regarding water, the circular mentioned the shortage of water in the regions where coal is produced and where coal chemical projects were to be located, and warned of the threat to social development posed by projects that consume ten tons of water to produce one ton of liquefied coal product. It also specifically pointed out that the annual amount of water consumed by a single large-scale coal chemical plant is the equivalent of that used by more than ten million people per year, and that the proposed plants have the capacity to break the critical water balance in the regions where they are built. Other specific problems the announcement cited included: the risks associated with investing up to several billion RMB in technologies still in the early stages of development and commercialization; the strain rapid growth in the coal chemical industry will place on China's coal resources; the irresponsible behavior of companies that use coal chemical projects to seize valuable coal resources; a concern that most of the projects didn't have the necessary economies of scale to be profitable; and the risk of overcapacity from "blind development" (mangmu fazhan) (NDRC, 2006).

In addition to announcing the moratorium on all coal to liquids projects under 3 mta, other measures were announced to help guide the industry's development. These included discouraging local governments from approving new coal to liquids projects until the national plan for the coal chemical industry was complete; declaring that only projects that have successfully completed the demonstration phase were allowed to expand their production size; prohibiting the diversion of water needed for daily life or 
agriculture to coal chemical projects and recommending strict control over the development of coal to liquids projects in areas short of water; discouraging the permitting or construction of coal chemical projects that do not have comprehensive waste water management systems; and forbidding the breaking of projects into smaller parts in order to win project approval or otherwise circumvent the approval processes. But in spite of these risks and problems, the announcement ultimately concluded that because of the coal to oil industry's importance to China's oil substitution strategy, coal to oil pilot and demonstration projects should be built, the pace of industrialization should be quickened, and large scale coal to oil plants should be built in a timely fashion (NDRC, 2006).

This 2006 announcement was a response to the fact that in addition to the largescale coal to oil projects already mentioned, other smaller companies, encouraged by the government's endorsement of coal to oil as part of its energy security strategy, were rushing to profit from high oil prices by developing projects. On the heels of the NDRC's announcement, one of China's official news agencies stated

It is reported that a total of 30 coal liquefaction projects are under detailed planning or at the stage of feasibility study in the country. According to conservative estimates, the total capacity would exceed 16 million tons, and investment would surpass 120 billion yuan (15 billion dollars). Insiders predicted that China's annual oil output liquefied from coal will reach 50 million tons by 2020. (China Daily, 2006)

Producing 50 million tons per year of synthetic oil from coal by 2020, as suggested in the article, would have required China to construct the equivalent of ten 5 mta plants or over sixteen 3 mta plants in just under 14 years, and also would have committed enormous 
amounts of coal, water, and capital to the endeavor. Given that in 2006 China had yet to successfully develop even one large scale project, the prospect of the industry developing to such a massive scale seemed extraordinarily ambitious, if not completely unrealistic. Nonetheless, that some "insiders" were making such predictions is an indication of the level of private-sector enthusiasm within China for coal to oil, and the potential for profits seen by energy and mining companies. Thus, the government was compelled to step in and issue a statement that addressed the industry directly in an attempt to prevent overheating and discourage small-scale forays into the industry. In spite of this, it is worth noting that the announcement was not necessarily a vote against coal to oil development, but rather an attempt to slow and moderate its development.

Shortly after the NDRC's July 2006 announcement, in December 2006, the NDRC in released for comments a draft of China's "Medium- and Long -Term Development Plan for National Coal Chemical Industry." Although only a draft plan intended as a starting point for discussions at a meeting of industry and provincial experts in Beijing in December 2006, to be later revised (China Chemical Industry News, 2006), the ambitious projections contained in the draft for the coal chemical and coal to oil industries gained a great deal of domestic and international attention. Most notable was the plan's call to invest more than one trillion RMB (U.S. \$128 billion) in the coal chemical industry between 2006 and 2020. According to the plan, China would "produce 1.5 million tons of coal-based oil in 2010, 10 million tons in 2015 and 30 million tons in 2020. Coal-based oil will make up 4\% and 10\% of total oil product in 2015 and 2020 respectively" (Sina, 2006). 
Extremely ambitious targets were also set for coal-based methanol, DME, and olefins, and the plan called for the creation of seven large coal chemical bases through the country. Notably, it stated that "the middle and lower reaches of the Yellow River, where Inner Mongolia, Shaanxi and Ningxia meet, will form China's largest substitute fossilfuel production base, producing 11 million tons of coal-based oil and 7 million tons of dimethyl ether annually" (Figure 5) (Asia Times Online, 2006).

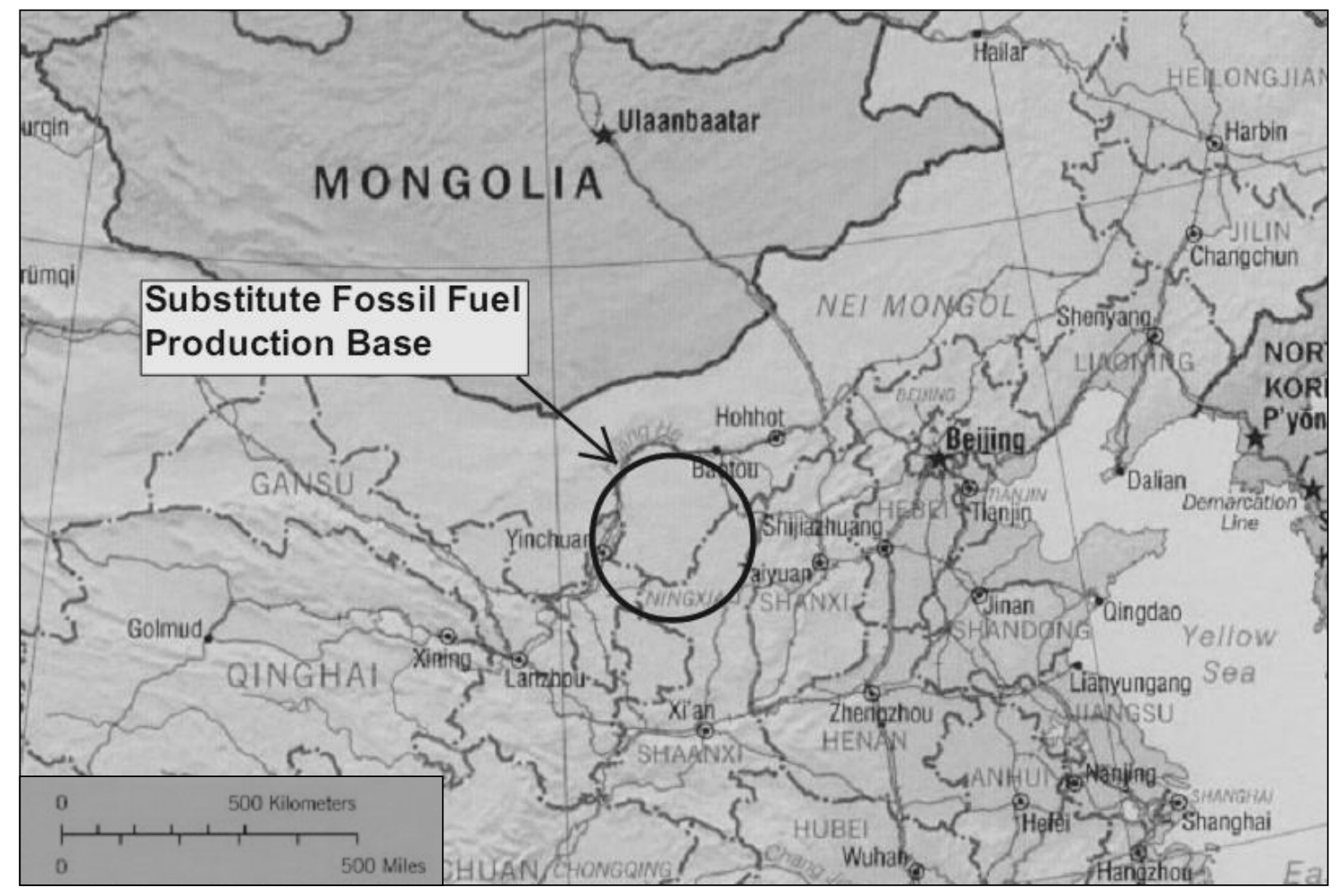

Figure 7. Approximate Location of China's Largest Substitute Fossil-Fuel Production Base

The draft plan also called for the construction of a pipeline to transport fuels produced in the middle and lower reaches of the Yellow River basin to consumption 
centers in Beijing, Tianjin, and Tangshan. The proposed pipeline would be $2000 \mathrm{~km}$ long and be built with a total investment of 8 billion RMB (approximately one billion dollars) (Asia Times Online, 2006). Thus, in spite of the concerns about runaway development, at the end of 2006 it still appeared the Chinese government fully supported the development of a massive coal to oil industry.

Beginning in 2006, there were also indications that perhaps not all decision makers in the government supported coal to oil development. In October 2006, an official from the powerful Development Research Center of China's State Council dismissed coal to oil as irresponsible and inefficient, citing coal to oil's low energy efficiency and high carbon dioxide emissions (Biopact, 2006). Later, in June 2007, an unnamed official from the NDRC was quoted as saying China was considering halting the development of all coal to oil projects because of their high capital costs, lack of mature technology, and high demands on both coal and water resources (Xinhua, 2007).

The high stakes of coal to oil investments and their potential impact on China's energy security led to vigorous debate within the academic and policy community in China starting in 2006. Dozens of articles were published analyzing the logic and rationale for coal to oil, with conflicting views and opinions the norm.

Those arguing in favor of coal to oil cited energy security concerns and the coming era of high international oil prices, the need to domestically develop advanced clean coal technologies (Wang, 2008, 16), and the role coal to oil projects might play in opening up and developing China's interior and less-advanced provinces, both by creating jobs and stimulating the economy (Meng et al. 2008, 80). Supporters also 
continued to make bold predictions about the future size of the industry and its potential energy security contributions. In 2007, for example, the China Coal Science Academy's Coal Chemical Department predicted that by 2020 China would be producing 50 million tons of oil from coal, and that 400 billion RMB would be invested in the industry (Economic Information Daily, 2007). Provincial authorities, among others, touted the importance of coal to oil to China's energy security. "It is very important to promote industrial-scale coal liquefaction," said Zhao Shuanglian, vice-chairman of the Inner Mongolia Autonomous Region. With CTL projects, "we can turn coal mines into oil fields to ensure energy security for China" (Xinhua, 2009).

Persuasive arguments in opposition to the coal to oil industry were being made by academics, industry experts, and officials with ties to the government. The opposition cited the industry's prohibitively large coal and water demands, the immaturity of existing technologies, and large carbon emissions as reasons to halt or minimize development. Others argued that unless coal to oil was developed on a massive scale it would only have a minimal impact on China's overall foreign oil dependence - and even then it wouldn't solve the country's energy security problem. An example of an article opposing coal to oil development was published in Chemical Engineering and Equipment by the Fuzhou Information Technology Research Center, in which the author lists seven reasons why China should think hard about developing coal to oil. First, the author argues that China may not be as rich in coal as people often assume given the rate at which it is being depleted and China's large population. Second, because of coal to oil's large CO2 emissions, vigorously developing coal to oil would be contrary to the successful 
implementation of China's national climate change program. Third, coal to oil's large water demands combined with the requirement that plants be built in parched coal-rich provinces like Shanxi, Shaanxi, and Inner Mongolia, means that such projects will not only worsen the water situation in the areas they are built, but that a prolonged drought could affect the plants' ability to operate normally. Fourth, the ecological impact of the plants would be large due to their enormous size, their waste water emissions, and the number of people they would employ. Fifth, coal to oil plants are extremely inefficient users of resources. Sixth, the unproven nature of much of the technology and the enormous capital investment needed to build a plant makes for enormous risk. Finally, bringing coal to oil to scale in China would exert tremendous pressure on China's coal resources, which would not only drive up the price of coal and diminish the profitability of the plants, but deplete China's finite coal resources in a shorter period of time (Xiao, 2008).

On energy security, an additional article pointed out that Shenhua's near-term projection of 3 million tons of synthetic oil per year was only equivalent to 2-3 tankers worth of oil, and that for China, with its massive and growing oil demand, this amount is but a drop in the bucket (bei shui che xin) (Chu, 2008, 16). Others questioned the logic of using one finite resource to substitute for a different finite resource. Zhou Dadi, Director Emeritus of China's NDRC-affiliated Energy Research Institute, was quoted in 2009 as saying "coal to oil is not feasible in China...to use one scarce resource to replace another scarce resource is worth nothing” $(\mathrm{Mu}, 2009,80)$. In general, numerous articles and 
statements over the past five years show that many within China questioned the wisdom of developing a coal to oil industry.

Signals from the government, although generally supportive of coal to oil development, offered few clear directives. In 2007, the government released two important reports: "The Eleventh Five-year Plan for the Coal Industry" and the "The Eleventh Five-year Plan for Energy Development." The Eleventh Five-year Plan for Energy Development, published in April 2007, called for speeding the development of the coal to oil, biofuels, and coal chemical industry as part of China's oil replacement strategy, while The Eleventh Five-year Plan for the Coal Industry (published three months later) called for developing China's coal-based liquid fuels sector and established the goal of having one million tons of coal to liquids production at the industrial demonstration phase by the end of the eleventh five year plan (2006-2011). Other government announcements that touched on coal to oil were also equal parts supportive and vague. For example, other announcements advocated for "the sustainable development of coal-based clean fuels and the comprehensive, efficient utilization of coal resources" (iCET, 2008, 39). In general, most policy statements made through 2007 and 2008 were supportive of coal to oil development, and of coal to liquids development in general, but they were also vague in their prescriptions, did not differentiate clearly among the various subsectors of the coal to liquids industry, and did not set any meaningful long-term targets or goals.

On August 4, 2008, over two years after its last announcement about the coal to oil industry, the NDRC issued its most definitive statement to date, ordering that all but 
two of China's coal to oil projects be halted. The two projects allowed to continue developing were Shenhua's indirect coal to oil project underway in Inner Mongolia and the planned joint venture between Shenhua-Ningxia and Sasol in Ningxia, which was still in the feasibility study stage. The reasons given for all but halting development were almost identical to those cited in 2006, including the environmental pressures associated with coal to oil (and other coal chemical processes), such as high carbon dioxide emissions; large water demands in draught-stricken regions; the fact that coal to oil is "a technology-, talent- and capital-intensive project, but most domestic enterprises lack advanced technologies, management experience and equipment" (China Daily, 2008); the inefficient use of coal resources by coal to oil projects; and the large capital investments needed and accompanying financial risk (NDRC, 2008; Zhang, 2008).

As in earlier statements and media reports, it was still estimated that "the output capacity of the existing and the planned CTL projects combined to equal roughly 16 million tons, with investment planned at 120 billion yuan (US $\$ 17.55$ billion) (China Daily, 2008). In a 2008 article by Pan Liansheng of China's powerful State Council State-owned Assets Supervision and Administration Commission, the situation was described as "All kinds of businesses, all kinds of funds have entered the coal chemical industry, including coal companies, power companies, chemical companies, state funds, private funds, domestic funds, international funds. The scale is so big, the investment is so huge, the pace of action is so fast that it leaves people speechless" (ling ren ze she) (Pan, 2008, 1). 
Reaction to the NDRC's announcement was mixed. Some in the industry bemoaned the darkened prospects for investment in coal to oil created by the announcement, while others praised the foresight of the NDRC in light of the technical, financial, and environmental obstacles posed by large-scale coal to oil development (China Daily, 2008). As the NDRC was making its announcement, world oil prices were dropping precipitously from a pre-financial crisis high of $\$ 147$ per barrel to less than $\$ 40$ per barrel in early 2009 . Enthusiasm for coal to oil suddenly seemed to be waning and the future of the industry was mired in uncertainty.

\subsection{China's Coal to Oil Industry Today}

The most recent announcement from the government regarding coal to oil was made by the State Council on September 26, 2009 as part of a larger announcement on the problem of overcapacity and duplicated investment in several industries, including the coal chemical industry. The announcement called for steadily carrying out demonstration projects for the construction of a modern coal chemical industry and evaluation of the demonstration work, meaning that some elements of the industry would proceed, but it also stated that "in principle no new projects would be approved in the coming years" (NDRC, 2009). In a press conference regarding the announcement, held on December 30, 2009, Li Ningning, Deputry Director General of the NDRC, elaborated on the overcapacity problem in the coal chemical industry, stating that the total capacity of announced coal to oil projects in China was now over 40 million tons per year. Later in the press conference, Long Huayuan, Deputy 
Director of Raw Materials at the Ministry of Industry and Information Technology, discussed some of the problems facing the modern coal chemical industry (which includes coal to oil), stating:

The governments in some coal producing regions are one-sidedly pursue economic growth regardless of the ecological environment, the water resources carrying capacity, and the fact that the modern coal chemical industry is in the demonstration phase of development, and they blindly and overeagerly plan large-scale modern coal chemical projects without considering the energy efficiency of the projects, the availability of markets for those products, or the competitiveness of the products.(NDRC, 2009a)

Mr. Long also pointed out the emerging contradiction between the rapid development of the coal chemical industry and the availability of water resources in coal-rich provinces, reiterating the policy that the government will not approve any new modern coal chemical industry demonstration projects for at least three years.

Present-day information is vague regarding the exact number and status of coal to oil plants under construction, undergoing feasibility studies, or announced. When a reporter at the 2009 NDRC press conference asked how many coal to oil projects had been approved, the question went unanswered. And while some reports have stated that over thirty coal to liquids projects were in the detailed planning or feasibility study stage, the International Energy Agency estimated in 2009 that over 80 coal to liquid projects have been announced in China in the past few years (IEA, 2009, 104). Because of the ambiguity in the data, public statements, and terminology, it is almost impossible to determine exactly how many plants have been announced, what they will produce, how much they will produce, and how far along they are in planning or construction. However, based on my research and publicly available information, it 
appears there are five main projects in operation, under construction, or close to beginning construction, and that at the moment these five projects make up the core of China's emerging coal to oil industry.

The project that has received the most attention over the past six years is Shenhua's direct coal to oil project in Ordos, Inner Mongolia. As mentioned earlier, the project construction began in 2004 ; it is the first large-scale direct coal to oil project of its kind anywhere in the world. The project's initial phase called for an output of one million tons per year of liquefied product, of which seventy percent will be diesel. The project will eventually expand to $3.2 \mathrm{mta}$ and then 5.0 million mta pending successful completion of each stage. Although the plant was expected to begin production in 2008, the project finished its first 300 hour trial run only in December 2008 (successfully producing quality diesel), and a second trial run of 1000 hours was completed in 2010 (Xinhua, 2009). The plant has yet to enter into fulltime operation but has tested the diesel fuel in automobiles and is preparing to start the second phase of construction pending government approval.

A second large-scale coal to oil plant is being planned for Dongning, Ningxia Autonomous Region, to be owned, built, and operated by Shenhua-Ningxia Coal Company and Sasol. The plant, which is one of the original two Sasol began targeting for development as early as 2004 , will produce 3.85 million tons of diesel per year using the indirect coal to oil method; total investment is estimated at 85 billion RMB (approximately $\$ 12$ billion). The project completed a second feasibility study in early 2010, had its environmental impact assessment approved by the State Environmental 
Protection Agency at approximately the same time, and is now applying for approval to proceed from the NDRC (Xinhua, 2010).

The remaining three projects are unique because they were not expressly allowed to continue developing in the NDRC's August 2008 announcement. Xinhua explained the contradiction, stating

In September 2008, the NDRC followed up with a circular, ordering a halt to almost all projects except for the Shenhua Group's direct CTL project and an indirect CTL plant proposed in northwest China's Ningxia. The directive, combined with the impact of the global financial crisis, cooled enthusiasm for many CTL projects in China. However, Yitai Group and Lu'an managed to keep their projects on the list. (Xinhua, 2009)

I will later discuss why these projects may have escaped Beijing ban on development, but for now it is worth noting the contradiction between the official NDRC statement and Xinhua's rapid acknowledgement that other projects would continue in spite of the restrictions.

China's Lu'an Group originally received NDRC approval in February 2006 for a 160,000 ta coal to oil project, to be situated in Tunliu, Shanxi Province, and on December 22, 2008 the plant successfully produced synthetic oil from coal. According to the company's website, it plans to expand to 3 million tons per year by 2012 , add a second 3 million ton per year between 2012 and 2015, and eventually produce 15 million tons of synthetic oil in 2020 by establishing plants in other provinces such as Xinjiang and Inner Mongolia. The Lu'an project uses wholly owned Chinese intellectual property produced by Synfuels China, which was “jointly founded in 2005 by the Institute of Coal Chemistry, Inner Mongolia Yitai Group, Shenhua Group, 
Lu'an Group, Xuzhou Mining Group and Lianshun Energy Co., Ltd" (Greencar Congress, 2009).

China's Yitai Group announced a successful test run with its 160,000-ton indirect coal to oil facility on March 23, 2009, producing quality diesel oil and naphtha. Based in Ordos, Inner Mongolia, Yitai Group's coal to oil project was approved by the central government in 2005 and began construction in 2006 with an investment of nearly 2.7 billion yuan (395 million U.S. dollars (Xinhua, 2009). The final project, by China's Yankuang Group, received initial government approval in January 2008 for a large two-phase coal to oil project in Yulin, Shaanxi Province. The first phase is planned for $1 \mathrm{mta}$ and will cost 10 billion RMB (approximately $\$ 1.38$ billion). The second phase, provided the Yankuang project proceeds, will expand the project to 5 mta and cost an additional 50 billion RMB (China Coal Resource, 2009). Yankuang aims to produce $10 \mathrm{mta}$ of oil products by 2020 , a plan that will involve a total investment of US $\$ 8$ billion (Steel Guru, 2008). Table 1 outlines the current projects and plans for development. 
Table 1. China's Five Flagship Coal to Oil Projects, 2010.

\begin{tabular}{|c|c|c|c|c|}
\hline $\begin{array}{l}\text { Owner, Type } \\
\text { of project }\end{array}$ & Location & Size & Investment & Status \\
\hline $\begin{array}{l}\text { Shenhua, } \\
\text { Direct Coal } \\
\text { to Oil }\end{array}$ & $\begin{array}{l}\text { Ordos, } \\
\text { Inner } \\
\text { Mongolia }\end{array}$ & $\begin{array}{l}\text { Phase 1: } 3.2 \mathrm{mta} \\
\text { (broken up over three } \\
\text { one mta lines); } \\
\text { Phase } 2: 5 \mathrm{mt} / \mathrm{a}\end{array}$ & $\begin{array}{l}\text { Phase 1: } \$ 3.6 \\
\text { billion }\end{array}$ & $\begin{array}{l}\text { Conducting trial } \\
\text { runs of first } 1.0 \\
\text { mta line }\end{array}$ \\
\hline $\begin{array}{l}\text { Yankuang, } \\
\text { Indirect Coal } \\
\text { to Oil }\end{array}$ & $\begin{array}{l}\text { Yulin, } \\
\text { Shaanxi }\end{array}$ & $\begin{array}{l}\text { Phase } 1 \text { (trial): } 1 \mathrm{mt} / \mathrm{a} \\
\text { Phase 2: } 5 \mathrm{mt} / \mathrm{a} \text { (by } \\
\text { 2013); } \\
\text { Phase 3: } 10 \mathrm{mta}\end{array}$ & $\begin{array}{l}\text { Phase 1 (trial): } \\
\$ 1.5 \text { billion } \\
\text { Phase 2: } \$ 7.35 \\
\text { billion } \\
\text { Phase 3: Up to } \\
\$ 8 \text { billion }\end{array}$ & $\begin{array}{l}\text { Waiting full } \\
\text { approval; trial } \\
\text { construction } \\
\text { underway }\end{array}$ \\
\hline $\begin{array}{l}\text { Lu'an, } \\
\text { Indirect Coal } \\
\text { to Oil }\end{array}$ & $\begin{array}{l}\text { Tunliu, } \\
\text { Shanxi }\end{array}$ & $\begin{array}{l}\text { Phase } 1 \text { (trial): } 160,000 \\
\text { t/a } \\
\text { Phase 2: } 3 \mathrm{mta} \text { (by } \\
\text { 2012) } \\
\text { Phase 3: } 6 \mathrm{mta} \text { (by } \\
\text { 2015) }\end{array}$ & Unknown & $\begin{array}{l}\text { Trial completed, } \\
\text { entering } \\
\text { production }\end{array}$ \\
\hline $\begin{array}{l}\text { Shenhua- } \\
\text { Ningxia \& } \\
\text { Sasol, } \\
\text { Indirect Coal } \\
\text { to Oil }\end{array}$ & $\begin{array}{l}\text { Dongning, } \\
\text { Ningxia }\end{array}$ & Phase 1: $3.2 \mathrm{mta}$ & US \$7 billion & $\begin{array}{l}\text { Feasibility } \\
\text { study done, } \\
\text { awaiting final } \\
\text { approval }\end{array}$ \\
\hline $\begin{array}{l}\text { Yitai, } \\
\text { Indirect Coal } \\
\text { to Oil }\end{array}$ & $\begin{array}{l}\text { Ordos, } \\
\text { Inner } \\
\text { Mongolia }\end{array}$ & $\begin{array}{l}\text { Phase } 1 \text { (trial) } 160,000 \\
\text { t/a Phase } 2: 480,000 \text { t/a }\end{array}$ & $\begin{array}{l}\text { Phase 1 (trial): } \\
\$ 2.2 \text { billion } \\
\text { Phase 2: US } \$ 5 \\
\text { billion }\end{array}$ & $\begin{array}{l}\text { Trial completed, } \\
\text { entering } \\
\text { production }\end{array}$ \\
\hline
\end{tabular}

Source: Zhang et al. 2009, table 1.

\subsection{Summary}

Over the past ten years China's coal to oil industry has developed from nonexistent to being on the cusp of producing several million tons per year of synthetic oil. Beginning in roughly 2004 and lasting until late 2008, ambitious plans were announced to invest in and develop a large-scale coal to oil industry in China. Government 
announcements and early support of coal to oil fed the enthusiasm of domestic and international energy companies. In 2006, recognizing the potential for the industry to become overheated and associated significant financial risks, and the potentially large environmental and resource impact of the industry, the NDRC announced new guidelines limiting the development of only the largest CTL projects. The announcement did little to halt the rush to invest in coal to liquids, forcing the government to announce in late 2008 that all but two projects were forbidden from moving forward. Although several proposed projects have announced they would cease development, three other smaller-scale projects operated by Chinese companies (and using Chinese intellectual property) continued to advance. In late 2009 the government announced that no new projects would be approved for at least three years, and that the current projects were to focus on solving technical and management challenges, achieving industrial scale production, and gathering data on the economics and resource impacts of coal to oil.

As will be explained in greater detail in the following section, it is important to note that all five of the coal to oil projects still under development are located in the provinces of Shanxi, Shaanxi, Ningxia, and Inner Mongolia (Figure 8, P.71). These provinces constitute the heart of China's coal industry, and the coal producing regions within these provinces are primarily located within the Yellow River basin. This industrial consolidation in the Yellow River basin is in line with the development strategy in the 2006 draft plan for the Medium- and Long -Term Development Plan for National Coal Chemical Industry, which called for making the middle and lower 
reaches of the Yellow River, where Inner Mongolia, Shaanxi, and Ningxia meet, the largest substitute fossil fuel production base (Asia Times Online, 2006). While the location of this industrial consolidation is logical given the geographic prerequisites of locating coal to oil projects in close proximity to abundant coal resources and a reliable water source, the environmental and resource conditions of this region also create considerable challenges. The following section will focus on those challenges and the other negative externalities created by coal to oil development, as well as the efforts that have been undertaken to address them.

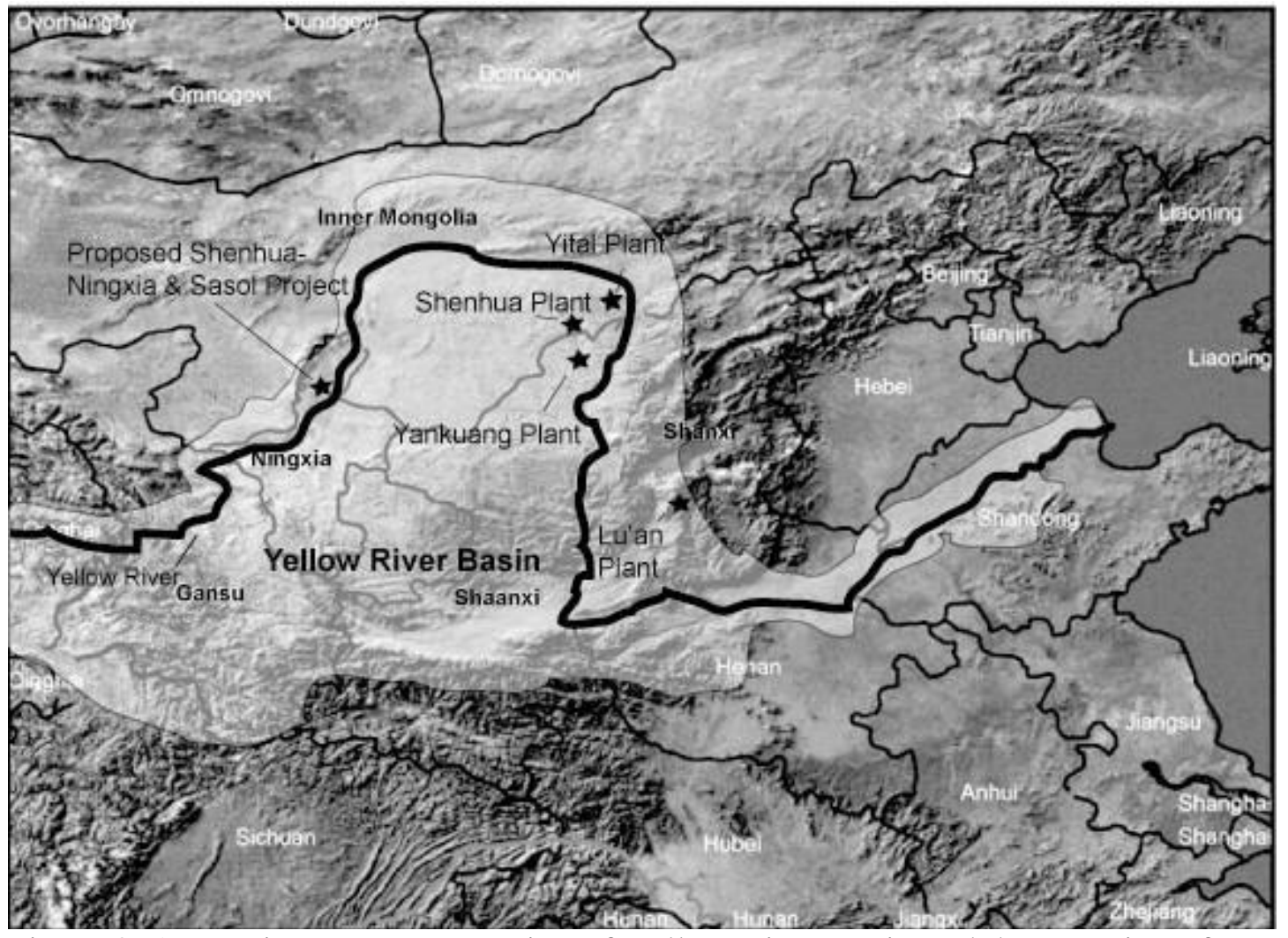

Figure 8. Approximate Representation of Yellow River Basin and the Location of

China’s Five Flagship Coal to Oil Projects ${ }^{1}$

\footnotetext{
${ }^{1}$ Figure was created using ARC GIS and Adobe Illustrator software, making it impossible to include scale.
} 


\section{Chapter 5: Analysis - Focus on Resource and Environmental Issues}

\subsection{Introduction}

My interest in China's coal to oil industry began in 2006 when the ambitious plans for developing the industry were first being announced. Between the NDRC's draft plan for the mid- and long-term development of the industry and the fast pace at which foreign and domestic energy companies were announcing projects, it seemed that coal to oil development was a foregone conclusion. Assuming that China would be producing 10 million tons of synthetic oil from coal by the year 2010, as some were predicting, I was intrigued by what this would mean for China's energy security and yet concerned about the environmental implications. Although industry development assumptions have proven to be false and actual production today is less than one million tons per year, even at the time I found it hard to believe that China would rush headlong into coal to oil development given the industry's resource implications and the already fragile state of China's environment. While the potential energy security benefits of increasing domestic "oil" production were significant, so were the potential downsides of unfettered development.

The previous chapter shows that the government in effect has halted industry development pending the successful completion of the five projects already underway, and that earlier estimates on the size and scope of the industry, particularly with regard to timelines, were either premature, overstated, or both. But before drawing conclusions regarding the Chinese government's management of this industry reveals 
about energy and resource management policies as a whole, it is helpful to look indepth at some of the specific resource, environmental, and human geography issues directly affected by this industry and to investigate whether the government has attempted to account for them. Focusing on these specific issues will not only shed light on the nature and severity of the challenges confronted by the government as it pursues coal to oil development, but will also provide an opportunity to dissect the responses of both government and industry to these resource and environmental concerns. Such additional analysis will help address and answer the first two questions of this study ${ }^{2}$, as well as inform later discussion that attempts to situate this analysis within the larger body of knowledge about energy sector governance in China.

The following analysis will focus on three key issues related to China's resource, human, and environmental geography: the impact of coal to oil projects on water resources in the middle and lower reaches of the Yellow River basin; the greenhouse gas emissions associated with coal to oil development; and the potential impact of a large-scale coal to oil industry on China's coal resources. The second half of this analysis will discuss how the government is attempting to address these challenges.

\footnotetext{
${ }^{2}$ First, do the energy policies governing the development of the coal to oil industry in China reflect awareness on the part of the central government of the potentially negative environmental and resource impacts of coal to oil development in China? Second, how has the government attempted to balance resource and environmental constraints with the potential benefits of coal to oil?
} 


\subsection{Yellow River Water Challenges}

One of the most significant obstacles facing the development of China's coal to oil industry is the geographic limitation imposed by coal and water needs on where the plants can be located. As discussed in chapter two, coal to oil plants need to be located close to large coal reserves and near stable supplies of water. But the majority of China's coal reserves and the heart of China's coal mining industry are located in north China in the provinces of Shanxi, Shaanxi, Inner Mongolia, and Ningxia, a region already facing extreme water shortages. Large swaths of these provinces are within China's Yellow River basin, and, as mentioned, all five of the coal to oil projects under development are located in this watershed (see Figure 8). The region's large coal reserves and concentration of mining interests also mean that future coal to oil development (and coal to liquids in general) will be located here, as indicated by preliminary plans to make this region one of China's seven coal chemical bases and the heart of the coal to oil industry. But the already severe water problems facing the region create the risk that a large-scale coal to oil industry will worsen water shortages, intensify competition for already scarce water supplies, and could potentially lead to social unrest.

The Yellow River basin is a relatively densely populated, largely rural region that is heavily dependent on agriculture. It is relatively poor compared to the rest of China, especially when compared to the more developed eastern seaboard.

According to 2000 statistics, the Yellow River basin is home to some 110 million people or around 9 percent of China's total population.... While urbanization is increasing rapidly, about $3 / 4$ of the basin residents are still 
classified as rural and most of them depend on agriculture for their livelihood. Income levels in the basin are, on average, somewhat lower than national averages and the basin accounts for some 7 percent of national output. (Giordano et al. 2004, 5)

Arguably the largest developmental challenge in the basin is water scarcity, a problem that is exacerbated by the seasonal variability in Yellow River water flows (60 percent of Yellow River discharge comes between July and October) (Yang, 2010). Northern China has historically has had limited water resources; it is home to 43 percent of China's population but only 14 percent of the country's water supply (Yardley, 2006). Since the 1980s and the advent of economic reforms, competition for scarce water resources has been growing:

...competition among provinces has put pressures on natural resources within and between provinces, especially water in northern China. In the early 1980s, as water contradictions grew among riparian regions - especially within the Yellow River basin - the central government realized the importance of establishing a water allocation institution. (Wang, 2003, 96)

The Yellow River Conservancy Commission is responsible for managing the flow of the river and allocating water resources, but growing water demand from industry, urban development, and agriculture are exerting growing pressure on water supplies. Agriculture currently accounts for 75 percent of the Yellow River's total water withdrawal, with industrial, urban, and rural uses consuming the remaining 25 percent (Yang, 2010). Demand for water by all sectors of the economy has placed enormous stress on the river. "Depletion at present means that the Yellow River supplies are essentially fully allocated. Since the early 1970s, this has been reflected in the complete, or near complete desiccation of the lower reach at certain times each 
year" (Giordano et al. 2004, 8). In 2007-08, total Yellow River basin water

withdrawals were approximately 45 billion cubic meters (total depletion was 35 billion cubic meters), and approximately 76 percent of the river's total water resources were depleted by human uses. ${ }^{3}$ An additional 14 percent was depleted through river/canal evaporation or as other losses. Thus, only 10 percent of the river's runoff entered the sea, leaving very little excess water for flushing sediment, eliminating waste, and maintain a healthy river ecosystem (Zhu et al. 2005, 5). More advanced inter-basin water management practices have improved the situation in recent years, but droughts and floods remain a serious threats in the region and in 2009 the Chinese government was forced to declare its highest-level of emergency because of a severe drought in Henan, Hebei, and Shandong (three provinces bordering the lower reaches of the Yellow River) (Spiegel, 2009). It is no exaggeration to say that water scarcity threatens the livelihoods of tens of millions throughout the region.

Pollution is a major problem in the basin. The expansion of energy-intensive, heavily polluting industries and urbanization along the lower and middle reaches of the Yellow River since the early 1990s have led to large increases in wastewater and sewage discharged into the river. "The Yellow River Conservancy Committee reported that $33.8 \%$ of the river system's water sampled in 2007 registered worse than level five. That means it is unfit for drinking, aquaculture, industrial use and even agriculture, according to criteria used by the UN Environment Program” (Branigan, 2008). Water

\footnotetext{
3 Water depletion is a use of water within the system that renders it unavailable for further use.
} 
pollution is China is certainly not isolated to the Yellow River basin or north China, but the relative scarcity of water in these regions exacerbates the problem.

The water challenges facing Shanxi province are representative of the region as a whole. Shanxi is ranked second to last behind Ningxia in terms of total available water resources, and the per capita water allocated to residents of Shanxi is only 17 percent of the national average (and 4 percent of the world per capita average). It is estimated that 4.4 million rural village dwellers face drinking water shortages, and the groundwater level in Shanxi aquifers are dropping rapidly. At the same time, a 2002 study reported that "Every year, in order to extract and clean 300 million tons of coal, mining companies pump out and blacken 250 million tons of groundwater, which equals the total annual water supply to Taiyuan, the capital of Shanxi." Approximately 70 percent of this water is then dumped into Shanxi's waterways without processing (Kim, 2002, 59-60).

All of the major coal to oil projects under development or in planning stages are situated in close proximity to the Yellow River and are located in the middle and upper reaches of the Yellow River basin. If the five plants listed above successfully complete their trial operations and reach the first stage of their development goals by 2015, total production would equal approximately $10 \mathrm{mta}$ of synthetic oil. Using industry estimates of 10 tons of water consumed per ton of product produced, these projects would be consuming approximately 100 million tons of water per year, all of it extracted from the Yellow River basin watershed. Should these projects continue expanding and eventually produced 20 mta of synthetic oil, water demand would grow 
to approximately 200 million tons of water per year. While this volume in only a small fraction of the river's total depletion (approximately one half of one percent), it would represent a significant quantity in comparison to total urban, industrial, or rural demand (roughly 3-10 percent of each) ${ }^{4}$. Zhang Yuzhuo of Shenhua estimated in 2006 that allowing his company alone to meet its coal to oil water demands would require one percent of the Yellow River's water (Wang, 2006). Although the accuracy of this statement is questionable, it gives an idea of just how sizeable an impact coal to oil would have on water supplies in an area with severely limited water resources. It also raises an important question about where the water for coal to oil projects would come from. With Yellow River water already over allocated, and industrialization occurring at a rapid pace along the Yellow River, unchecked development of coal to oil projects would undoubtedly worsen an already severe problem.

\subsection{Managing Greenhouse Gas Emissions}

Numerous studies have pointed out the severe environmental impact climate change is likely to have in China. Problems that China is likely to encounter as a result of climactic changes include increased frequency of severe weather events, increased variability in precipitation patterns, and the threat of both water shortages and flooding as a result of altered seasonal river flows as glaciers melt. According to China's 2007 publication "China's Climate Change Program”, key sectors adversely affected by climate change will include the agriculture and livestock industry, forests and other

\footnotetext{
${ }^{4}$ Based on Yellow River water figures found in Giordano et al. 2004.
} 
natural ecosystems, water resources, and the coastal zones. These changes, should they occur, will be destabilizing to China as a whole, and they will affect disproportionately China's rural population. For these reasons and others, the central government in the past five years has taken significant steps to minimize greenhouse gas emissions and to reduce China's overall carbon intensity. ${ }^{5}$ While China is unwilling to place a cap on its future carbon emissions, it has made ambitious efforts to curb the growth in those emissions and to develop renewable, low-carbon sources of energy.

Developing a large-scale coal to liquids industry would increase China's carbon emissions and move in the opposite direction that China has charted for an otherwise ambitious carbon emissions reduction effort. As mentioned, the process of converting coal to oil is extremely carbon intensive and, without carbon capture and storage, results in the release of twice as much carbon dioxide as the production process for creating gasoline from petroleum in a well-to-wheels analysis. The IEA estimates that were China's coal to oil production to reach one million barrels per day in 2030 (approximately $50 \mathrm{mta}$ ), the industry would emit between 140 and $250 \mathrm{Mt}$ of CO2, depending on the production processes used. The estimates also suggest that should the industry reach (only) $30.75 \mathrm{mta}, \mathrm{CO} 2$ emissions would be between 100-190 Mt of CO2 (IEA, 2007, 367). Although this amount is only equivalent to $1-2 \%$ of China's total emissions, it is still significant and would move China away from, rather than towards, its goal of becoming a low-carbon economy.

\footnotetext{
${ }^{5}$ Carbon intensity is the amount of carbon dioxide emitted for each unit of economic output.
} 
5.4 The Challenge of Sustainably Managing China's Coal Resources

China's coal reserves are among the most abundant in the world and coal is China's primary source of energy. In spite of China's efforts to alter its reliance on coal by incorporating renewable energy, nuclear power, and natural gas into its energy mix, coal will remain China's main source of energy for decades to come. The IEA forecasts that even under the best case scenario for the policies governing the development of China's energy sector (known as the "Alternative Policy Scenario"), coal demand will still increase by approximately $70 \%$ between 2005 and 2030 (IEA, 2007, 364). The Asian Development Bank predicts that coal will account for over half of China's energy needs (in a significantly larger economy) in 2030 (Figure 9) (ADB, 2009, 148).

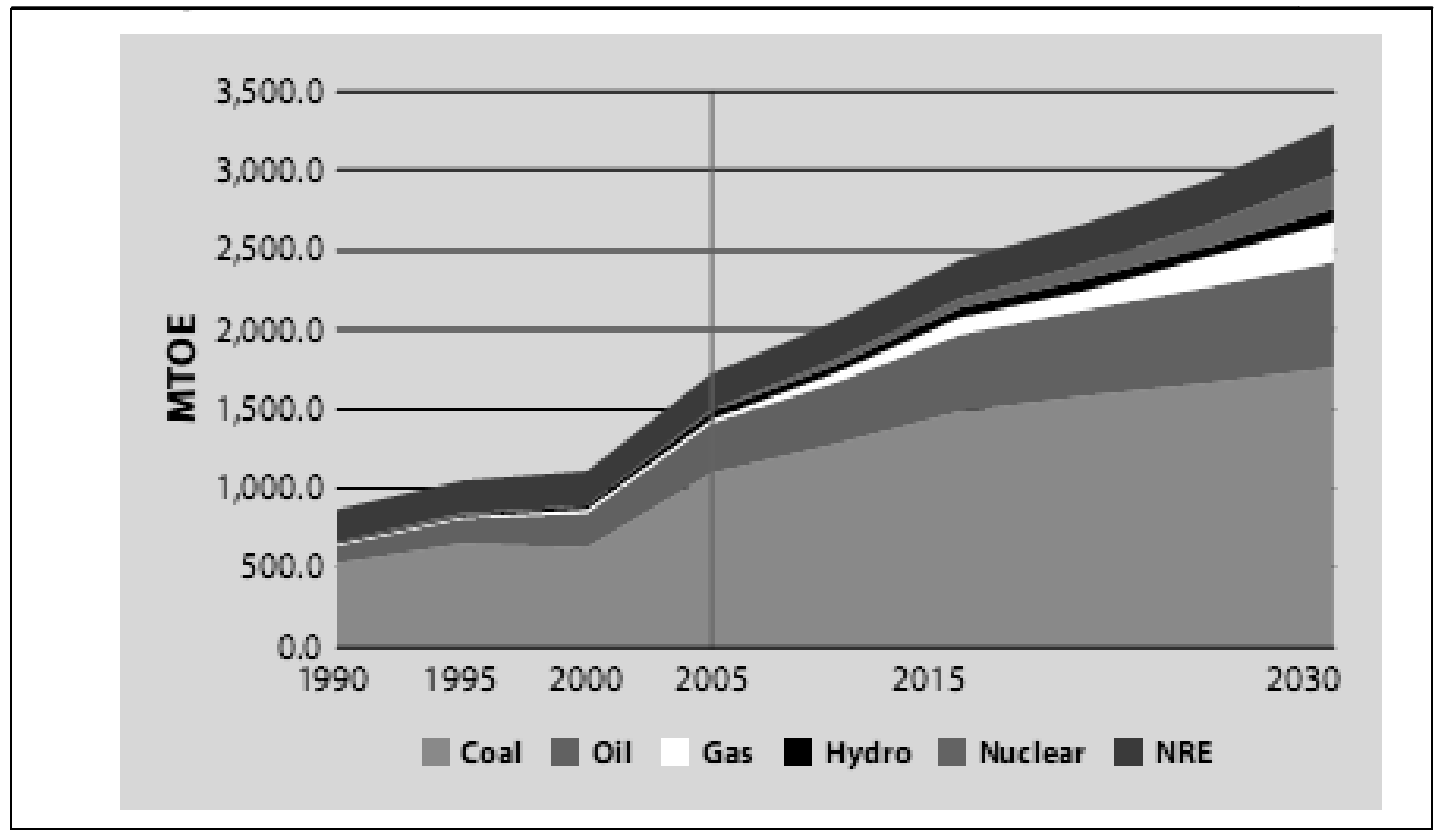

Note: $\mathrm{MTOE}=$ million tons of oil equivalent $\quad \mathrm{NRE}=$ New and Renewable Energy

Source: ADB, 2009, Figure 2.14.3

Figure 9. Primary Energy Demand - People's Republic of China. 
Coal, like every fossil fuel, is a finite resource and even China's enormous reserves will not last forever. The BP Statistical Review of World Energy estimates China's total proved reserves at the end of 2008 as 114,500 million tons of oil equivalent and predicts that, based on China's current reserves to production ratio ${ }^{6}$, China's coal reserves will last 41 years (2010). In a separate report prepared by the Energy Watch Group, the authors concluded that the steep rise in China's coal production over the past few years "must be followed by a steep decline after 2020 " and that "one should not be surprised if the peak of China's coal production is not far away" (2007, 27-29). A report by the Lawrence Berkeley National Laboratory reaches a similar conclusion, stating "Given the Ministry of Land and Resources estimate of 189 billion tons remaining domestic coal reserves and the historical production trajectory of other coal-intensive countries such as the United Kingdom, Japan, and Germany, Chinese production is likely to peak in the foreseeable future" (Figure 10) (Aden et al. 2009, 33) While China could conceivably rely on coal imports to meet domestic demand, doing so would worsen China's energy security predicament and create economic burdens not unlike those created by reliance on imported oil.

${ }^{6}$ If the reserves remaining at the end of the year are divided by the production in that year, the result is the length of time that those remaining reserves would last if production were to continue at that rate. 


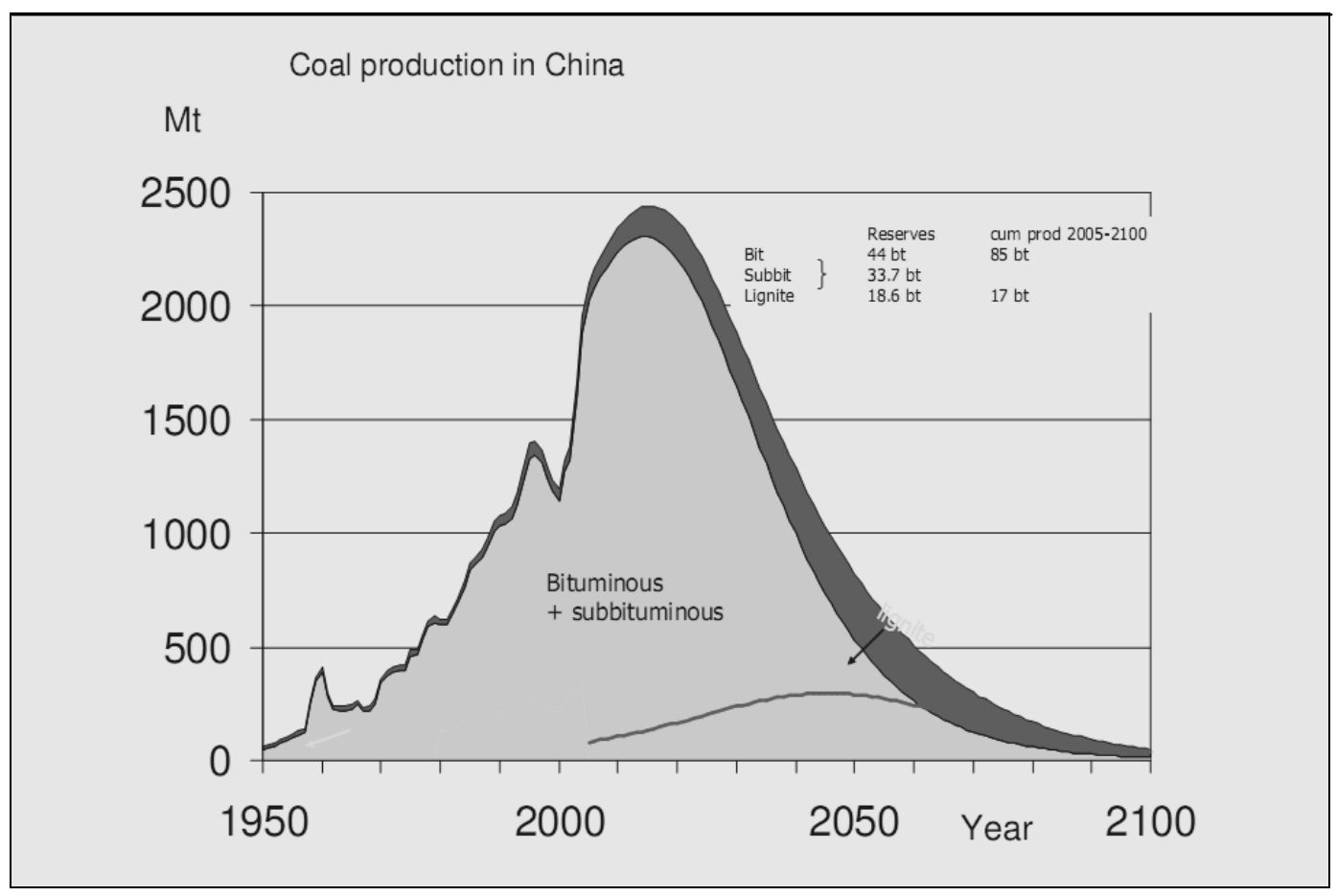

Source: Aden et al. 2009, figure A-3.

Figure 10. Coal Production in China - Scenario Based on Present Reserve Estimates.

As discussed earlier, coal to oil is an inefficient process for utilizing coal resources and requires between 3.5-4.0 tons of coal to produce one ton of liquefied product. Experts within China have pointed out the inefficiency of coal to oil projects and have questioned the wisdom of converting massive amounts of coal into transportation fuels. Assuming coal to oil is indeed profitable (not a foregone conclusion), coal mining companies naturally have an interest in extending their value chains and creating value-added products out of coal rather than just selling the coal to electricity producers or heavy industry. But the central government, the NDRC, and other ministries, which are responsible for managing the country's natural resources, must consider the efficiency with which those resources are consumed and the long- 
term pricing and energy security concerns associated with their rapid consumption.

This is yet another challenge posed by the development of a robust coal to oil industry.

5.5 Assessing the Central Government's Efforts to Address the Environmental and Resource Challenges Created by Coal to Oil Development

I have thus far outlined three specific resource and environmental issues that will be affected by coal to oil development. The following three sections will address two of my key research questions: whether or not the government's policies toward coal to liquids reflect an awareness of the environmental and resource challenges posed by the industry, and how the government has attempted to cope with these challenges. In general, I believe there is ample evidence that the government not only recognizes the resource and environmental challenges posed by coal to oil development, but is also taking concrete steps to mitigate those challenges.

\subsection{Efforts to Mitigate Water Resource Impacts from Coal to Oil}

In every government announcement made since 2006 regarding the coal to oil industry, water consumption has been mentioned as a top concern. In the NDRC's July 2006 announcement limiting the development of coal to oil projects to plants over 3 million tons per annum, water was mentioned as one of the negative impacts (buli de yingxiang) associated with the rush to develop the coal chemical industry. Statistics were given to reflect the extreme nature of the coal chemical industry's water consumption, including that "coal chemical projects often use up to several million cubic meters of 
water" and that "in some areas this is the equivalent to the amount of water used by several hundred thousand people or the amount of water held in more than 100 square kilometers of land." The 2006 announcement also stated that coal chemical projects should "on the basis of water volumes proceed" (liang shui er xing); prohibited the diversion of water from agricultural uses to the coal chemical industry; and called for the "strict control of coal gasification and coal to liquids projects in dry areas." The use of water saving technologies was also encouraged (NDRC, 2006).

Concern over the amount of water consumed by coal to oil projects was evident in later statements as well. In 2007, when an anonymous NDRC official suggested the government was preparing to halt all coal to oil projects, water was cited as one of the primary reasons behind this move. In the 2008 NDRC announcement halting the development of all but two coal to oil projects, water was again cited for why China needed to slow the industry's development. Specifically, the statement indicated there be determination of "the security situation of the amount of water needed by coal to oil projects" (NDRC, 2008). Most recently, in the December 2009 press conference about the NDRC's efforts to rein in overcapacity in the coal chemical sector, water concerns were included as one of the five contradictions and problems that exist in the coal chemical industry. In the press conference, Long Huayuan (Deputy Director of Raw Materials in the Ministry of Industry and Information Technology) stated

China's coal resources are mainly distributed in the arid and semi-arid regions of central and western China, and in these regions water is scarce and the ecological environment is fragile, creating a high industry cost factor. Due to overexploitation of groundwater in some areas, surface rivers and wells have dried up, and the groundwater table is dropping, creating severe difficulties 
related to drinking water. The contradictions between the coal chemical industry and ecological protection are growing more prominent. (NDRC, 2009a)

In this same press conference officials also scolded those who would blindly develop the industry without regard to ecological conditions (NDRC, 2009a).

In addition to official government statements, numerous articles written by experts and officials affiliated with the government have cited coal to oil's large water demands as a reason for opposing development or for developing the industry slowly. An article published by researchers from the China Chemical Information Center stated that relevant water departments have already pointed out that building water intensive industries in the middle reaches of the Yellow River "may lead to water wars between industry, agriculture, and ecological needs, and pose a serious threat to provinces in the lower reaches of the Yellow River" (Pan et al. 2008, 64). Even experts writing in favor of coal to oil development point out the water challenges associated with the industry. According to Tang Hongqing of Synthetic Oil Engineering Co., Ltd., "multilevel, largescale development of a coal chemical industry will inevitably squeeze agricultural and ecological water, damage the environment, and endanger environmental safety. The fact that the location of coal and water resources do not match is the coal chemical industry's greatest obstacle" $(2008,16)$.

While it is difficult to determine exactly how different projects plan to meet their water needs, the government appears to be monitoring the situation closely and in some cases there are plans in place to compensate for the increased withdrawals with savings in other sectors. Currently, Shenhua's direct coal to oil plant in Ordos, Inner Mongolia is 
meeting its water needs with water drawn from an aquifer 40-60 miles away. The plant will only be allowed to start drawing Yellow River water if it is permitted to expand to 3 mta and then 5 mta (DeWit and Watts, 2009), a decision that will be based, at least in part, on the demonstrated water needs of the first phase of the project. The Shenhua-Ningxia Sasol indirect coal to oil plant to be located in the Ningdong coal chemical base near Yinchuan, Ningxia will secure its water requirements from the Yellow River and it is estimated that the Ningdong coal chemical base will draw 100 million tons of water from the Yellow River every year (Sexton and Li, 2008). Although the Sasol technology consumes water more efficiently than other plants, the proposed plant output of over 3 mta makes it inevitable that it will be a major consumer of water in the province.

One of the plans under discussion to assist Ningxia's adjustment to increased water demand is the replacement of inefficient irrigation practices in Ningxia with more advanced techniques, thereby freeing up water to be reallocated to the coal to oil project. According to the managing director of Sasol Synthetic Fuels International, Ou Boyang, "Currently, the efficiency of Yellow River water used in Ningxia for irrigation is very low, so the idea of the regional government is to introduce sprinkle irrigation and other measures to reduce water demand. At present, the central government and Ningxia Autonomous Region government are taking steps to replace water demand" (Wang, 2010a). Wang Zhengwei, governor of Ningxia, explained the plan, saying

These projects do need a lot of water, but we have adopted measures to use water used in agriculture and transfer it to industry. In Ningxia, 93 percent of our water is used in agriculture. The method has been approved by the Ministry of Water Resources and is being promoted through the rest of the country. (Reuters, 2010) 
The idea driving this plan represents a rational approach to competing resource demand since agriculture is by far the largest consumer of water resources in the region and irrigation practices are notoriously inefficient and wasteful (it has been estimated that in Shanxi over half of irrigation water is lost before it reaches crops due to the poor irrigation infrastructure) (Kim, 2002, 60). Since 2003 the central government has been encouraging industrial water users, especially large enterprises, to invest in water saving projects for existing irrigation schemes in exchange for the right to use the saved water (Yang, 2010). While it is debatable how effectively local governments will implement these programs, or if they will achieve enough savings to compensate for the projected extra 100 million tons of water withdrawal demand, it nonetheless shows that the government is taking seriously the water resource challenges posed by the project.

For the three smaller plants moving forward, built by Lu'an, Yitai, and Yankuang, it is difficult to identify their water source or whether they are taking measures to compensate for withdrawal increases as very little information has been made publicly available. More research is needed.

\subsection{Efforts to Address Coal to Oil Greenhouse Gas Emissions}

The carbon-intensive nature of coal to oil projects is a challenge both for the Chinese government and the companies that are promoting the development of coal to oil. A plant that produces $3.5 \mathrm{mta}$ of synthetic oil would (without CCS) produce approximately $16 \mathrm{mtpa}$ of $\mathrm{CO} 2$, equivalent to a 3 giggawatt coal-fired utility plant (IEA, 2006, 24). In each of the previously mentioned NDRC announcements regarding coal to 
oil, C02 emissions have been cited as one of the key contradictions to be overcome if the industry is to continue developing. It appears that significant efforts are underway to deal with this challenge, and these efforts provide yet more evidence of government's attempts to compensate for the resource challenges imposed by this industry.

Utilization of carbon capture and storage technology is the only way to eliminate the carbon emissions associated with coal to oil processes. Shenhua is taking the lead in this effort, in cooperation with the U.S. Department of Energy and West Virginia University, through development of a large-scale CCS project for its Inner Mongolia operation that may eventually capture up to 3 million tons of $\mathrm{CO} 2$ annually (of a total 3.4 million tons produced). The three parties have already completed a pre-feasibility study and are now working on a demonstration project to capture and sequester 100,000 tons of carbon annually at a cost of US \$30.8 million dollars (Xinhua, 2010a). The project is expected to expand to capture one million and then three million tons of $\mathrm{CO} 2$ annually, with an estimated project cost of US $\$ 1.4$ billion (Morse et al. 2009, 7). Once completed, it would be the largest CCS demonstration project in the world.

For the Sasol-Shenhua-Ningxia project in Ningxia, Sasol announced in 2009 that it would incorporate a CCS option in the upfront design of the plant in order to make it carbon capture ready (Engineering News, 2009). Although there is no guarantee that the plant, if built, will implement CCS technology, the step is significant since it allows for the possibility of CCS at a future date with minimal retrofitting costs. Sasol is also actively looking for carbon storage locations in the vicinity of the proposed plant. While less information is available about the three smaller Chinese coal to oil plants, Yitai 
announced in 2010 that it would be investing one billion RMB to plant trees around Ordos to create a carbon sink, which will not only absorb carbon emissions but also help prevent desertification the region (Wang, 2010). Less is known about the Lu'an and Yankuang plants' plans for dealing with carbon emissions, but it is possible to conclude that there is recognition within the coal to oil industry in China that $\mathrm{CO} 2$ emissions and how they are dealt with will affect the long-term development of the industry.

\subsection{Recognition of Coal to Oil's Demand Pressures on Coal Reserves}

The impact of China's coal to oil industry on coal resources is directly correlated to the size of the industry, meaning there are no policies or fixes that can alter the relationship between synthetic oil produced and coal consumed. Therefore, it is difficult to pinpoint specific government policies that directly take into account the inefficient use of coal resources by coal to oil projects other than the government's overall cautious approach to developing the industry and managing its size. Policy statements over the past five years make clear that the government takes seriously the risk of allocating too much coal to the coal to oil industry; by halting all new projects for at least three years it is essentially placing a cap on the amount of coal that will be dedicated to the industry. In every statement issued by the government since 2006, the inefficient use of coal resources and high energy demands of the industry have been mentioned, and the government has also made clear that the future development of the industry will be determined by the energy needs of the demonstration projects underway. 
5.9 Central Government Recognition of the Challenges Posed by Coal to Oil's Resource Demands

The government's approach to the resource and environmental challenges posed by coal to oil development in these three specific areas demonstrates clearly that there is an awareness of the potentially negative consequences posed by coal to oil development, a recognition that coal to oil projects cannot be allowed to develop unchecked, and that it is irresponsible for the industry to blindly pursue its own profits and interests at the expense of critical resources such as coal and water. In addition to the resource and environmental concerns highlighted, there are other issues associated with this industry that rightfully give the government pause, such high upfront capital costs, questionable economics, and the presently immature status of the coal to oil technologies that China attempts to develop on its own.

At the same time, the government must balance these potentially negative impacts with the energy security benefits of developing a domestic coal to oil industry. As the International Energy Agency has pointed out, a large-scale coal to oil industry in China that produces between thirty and fifty million tons of synthetic oil per year will help minimize China's reliance on foreign oil imports by boosting domestic "oil" production. At current rates of domestic oil production, the production of forty million tons of synthetic oil per year would boost China domestic production by over one-third - far from a trivial amount. But, as has been shown, the government is not letting this potential energy security benefit blind it to the potentially negative impacts associated with a largescale coal to oil industry. Rather, the government is actively taking measures to regulate 
and slow the development of the industry and to mitigate or offset the negative consequences of coal to oil development on water resources and the environment. 


\section{Chapter 6: Key Findings and Implications}

\subsection{Introduction}

The Chinese government has overseen one of the greatest economic transitions in history and has succeeded in lifting China from the status of a third world country in the 1970s to that of a great power in the world economy and geopolitics. Effective governance has been key to this ascent, and as I have followed the development of China's coal to oil industry I have often been reminded of the comment made to me by a European Union trade representative in Beijing, who said "Say what you will about China's government, but govern they can. Govern they can." Is it conceivable that China would let its coal to oil industry develop unchecked in spite of potentially disastrous consequences for its environment, resource base, and social stability? Contrary to the premise I began with four years ago, at a time when China's environmental problems seemed at their worst, my answer now is no. The central government has too much at stake to allow the runaway development of one industry to worsen the outlook for two resources as critical to future development as water and coal, or to turn a blind eye its rapidly growing carbon emissions.

Researching this industry has provided many insights into China's energy policymaking style and the challenges facing the government as it attempts to reconcile competing domestic demands. China's style of energy governance has many flaws, and in the end, no matter what policies it chooses, it simply may never be able to simultaneously address the challenges of energy security, economic growth, sustainable development, 
and domestic social harmony. But it can balance those demands as much as possible, and it is my conclusion, with a few caveats, that the style with which Beijing has governed the development of the coal to oil industry is not only logical, but also quite sensible given the number of divergent issues and interests the industry affects. The notion I had in 2006 that China would allow the coal to oil industry to develop at a blistering pace without regard to the consequences has been to me disproven.

Of the three research questions this study has sought to answer, most important is the question about what the government's management of this industry reveals about energy sector governance in general. Unsurprisingly, my own conclusions and observations are generally in agreement with the findings of previous studies, and they support rather than disprove the opinions of informed observers. As mentioned in the introductory chapter, the difference between "perception" and "reality" as they relate to China's energy policymaking process could not be starker. When starting this study, I (like many) mistakenly believed that the central government was firmly in control of energy policy, that the term "state owned" really did equate to "state controlled," and that the authoritarian structure of the Chinese state really did create strategic purpose and coherence in the energy policy making arena. Thus, when I read pronouncements coming from China about producing tens of millions of tons of synthetic oil from coal the coming years, it seemed natural to conclude that this really was government policy, and that the decision had been made.

Gradually, I've come to a different conclusion. Ambitious statements about the industry's development almost always originated from sources within the mining and 
energy companies developing the industry, and the one document that appeared to show the government's commitment to developing a massive coal to oil industry, the Mediumand Long -Term Development Plan for National Coal Chemical Industry, was in fact only a draft plan that four years later has yet to be finalized. In short, I have realized that many of the earlier observations made about the nature of the energy policymaking process in China are generally true. Decentralization is an enormous problem facing the institutions governing China's energy sector, and one should not assume that policies originating at the center are being strictly followed, or that development can only take place with central government approval. Powerful energy companies do hold considerable sway, and when possible they will use their leverage and profile to promote or even influence policy decisions at the center. And, thanks in part to China's relatively weak energy institutions, the policy process is indeed reactive, ad hoc, incremental, and protracted.

But while the first two of these three challenges (decentralization and powerful energy companies) are undoubtedly problematic and impede the government's ability to create policy or regulate the energy sector, I believe there is a certain logic in the "muddling through" approach energy institutions sometimes take in setting policy. In the case of the coal to oil industry, this protracted, incremental style of policymaking may even have been to China's and the industry's long-term benefit. Before explaining this assertion, I will first describe my observations as they relate to the first two challenges, decentralization and powerful energy companies. 


\subsection{The Challenge of Decentralization}

Decentralization and the challenges it creates as provinces pursue self interest and economic gain is an obstacle often identified as impeding the government's ability to create effective energy policy. The most obvious challenge decentralization creates for the central government as it manages the coal to oil industry is the concern that coal to oil projects might continue developing beyond the central government's control, out of its view, and without approval. The multiple warnings in NDRC policy announcements for companies or provinces to not "break up projects into small parts" in order to avoid government controls indicates that the government does not always have firm control over events on the ground, and that the provinces may be directly or indirectly disobeying mandates from the center. As one article describes it, companies use a "decentralized, phased implementation approach to turn the small into big, which is not only beneficial to passing evaluations, but also allows them to occupy more resources" (Pan et al. 2008, 64). Other articles point out that project developers announce an eventual total planned capacity above the government's limits in order to be in compliance even though the initial phases of the project are small scale, a strategy designed to circumvent the central government's 2006 ban on plants with a capacity under 3 million tons per annum.(Coal Net, 2007).

Local governments have a great deal to gain from the development of multi-billion dollar coal to oil projects in their provinces, including tax revenue, local development and investment, job creation, and legitimacy in the eyes of the public. As was pointed out by Wang Zhengwei of Ningxia, when discussing the regional benefits of the proposed 
Shenhua-Ningxia and Sasol join venture, "If this project is formally completed, the investment of 58 billion yuan ( $\$ 8.50$ billion) will stimulate the economy. Once it is constructed, it will earn 30 billion yuan a year, and 10 billion yuan in taxes" (Reuters, 2010). Personal gains for local officials in the form of illegal taxes or bribes are also inevitable. Thus, there is every reason to believe that provincial governments favor and support coal to oil projects despite the central government's trepidation. It is telling that even in December 2009, after years of efforts to slow industry developments, the NDRC was still citing a figure of over $40 \mathrm{mta}$ of announced projects as it called for more measures to slow overcapacity. This is in spite of the fact that almost a year and half earlier it had announced that only two projects would be allowed to develop.

This study cannot definitively prove that provinces have directly disobeyed the orders of the central government, nor can it conclusively determine the actual status of all known and unknown coal to oil projects under development. Without traveling to the main coal producing regions, looking for oneself, and conducting extensive interviews, it is impossible to say with certainty how many projects are developing outside of the governments view or without its approval. My own conclusion is that the five projects I have mentioned are the flagships of the industry, but planning and development may be underway for new projects in Xinjiang, Shandong, or Northeast China. But my research directly supports the conclusion that decentralization is a significant challenge facing the central government as it attempts to plan and regulate China's booming energy sector, and that it must often rein in the activities of the provinces as they pursue local gain without regard to larger national interests. 


\subsection{Influential Energy Companies}

The power and influence of large, state-owned energy companies is another factor thought to influence energy policy in China, and coal to oil companies have made considerable effort to promote their goals in Beijing. Over the past four years Shenhua has been the most active supporter of coal to oil and has repeatedly emphasized the important energy security gains yielded by the industry while making overly optimistic statements about the size and scale of industry development. Shenhua has also been joined by industry executives from other coal companies in promoting coal to oil as an opportunity for China to develop domestic technologies using Chinese intellectual property. With the exception of the proposed Shenhua-Sasol joint venture in Ningxia, the remaining four projects are all utilizing (or at least partially utilizing) technologies derived from Chinese intellectual property, a fact that companies are quick to highlight when arguing in favor of coal to oil. Together, the emphasis placed by Chinese coal to oil companies on energy security and domestic intellectual property led to an unexpected finding regarding the extent to which companies use national narratives to promote their self interest.

As discussed in chapter two, energy security became a hot topic in the first half of the past decade as China's import reliance grew and commentators expressed concern over the U.S. Navy's control over sea lanes of communication, particularly in the Strait of Malacca. Coal to oil companies have latched on to that narrative to promote their projects as being in the national interest, and have more often than not used the importance of 
energy security as a way to elevate their projects in spite of concerns about water resources, finite coal resources, or carbon emissions. Arguably, in any country few arguments are as compelling, or used as frequently to justify a policy that reflects one's own, as well as the national interest, as "national security." Chinese companies are clearly no different, and this narrative has influenced private sector strategy for drumming up government support for the coal to oil industry.

Perhaps most interesting in this regard is the extent to which coal to oil companies seized on one of China's newest national narratives, "indigenous innovation” (zizhu chuangxin), which promotes domestic innovation and encourages Chinese companies to develop their own patents, technologies, and intellectual property. Over the past four years the coal to oil companies using Chinese intellectual property have attempted to link their projects to this particular narrative in hopes of gaining high-level government support (Pan et al. 2008). Confirmation of the efficacy of this narrative is that although the NDRC's 2008 announcement that called for the halting of all but two coal to oil projects, the projects by Yitai, Lu'an, and Yankuang were absent from the list. These three have continued to develop and achieve measured successes over the past two years, including Lu'an and Yitai's successful 2009 test runs of their small-scale indirect coal to oil projects that are under development (Xinhua, 2009). While impossible to confirm without further research, I would propose that the reason they have been allowed to continue developing is because they are using Chinese intellectual property, a critically important form of legitimacy in the eyes of the central government. 
Even the future of the proposed joint venture between Shenhua-Ningxia and Sasol is being transformed by the drive to develop and utilize Chinese technology. In early 2010, near the time the project was receiving approval for its environmental impact statement, it was reported that the Ningxia government and Zhang Guobao, head of China's National Energy Administration, were calling for the submission of an alternative plan for the project that excluded Sasol from the proposed joint-venture in favor of a plan that used exclusively homegrown Chinese technologies (Dow Jones, 2010). Part of the reason for this may be Sasol's unwillingness to transfer intellectual property to China in return for building the project, and the extreme caution Sasol has shown in protecting its proprietary technology (Creamer, 2008). It has yet to be determined if and how the project will proceed, but this example is symbolic of both the emphasis China places on indigenous innovation and the ability of Chinese companies to capitalize on that narrative.

The national narratives of energy security and indigenous innovation have both been used successfully before to advance private sector interests. The indigenous innovation narrative was used by the developers of China's domestically developed $3 \mathrm{G}$ telecommunications standard (known as TD-SCDMA) to gain government support, eventually resulting in the central government's requiring China Mobile to adopt this particular standard despite its initial reluctance.(Gao, 2009). Similarly, the energy security and the "Malacca dilemma" narrative has been used by the Yunnan government and Sinopec (one of China's three national oil companies and its largest refiner of crude oil) to justify building oil and gas pipelines from the Bay of Bengal through Myanmar to the capital of Yunnan, Kunming (Kong, 2010). While it is difficult to determine how 
significant energy security, indigenous innovation, or the national interest was as a part of these companies' motivations, one should not overlook the fact that in each case the companies stood to gain monetarily if their suggested proposals were adopted.

In the case of the coal to oil industry, the potential for profit is arguably the prime mover behind the activities of the companies involved. The profit potential of coal to oil and coal to liquids development was described in a 2010 media report about Inner Mongolia's booming coal chemical industry. According to the article, when mining companies use the coal they mine to generate electricity themselves (known as "coal by wire"), the coal becomes almost eight times as valuable as it would be if they simply mined and sold it. But when converted into processed products, like natural gas, DME, synthetic oil, or methanol, the coal is up to twenty times as valuable as it would be if sold to electricity generators. With this in mind, the provincial government Inner Mongolia created a plan to convert up to half of its coal production into value-added coal chemical products. And while the size of the potential profits are high, the scale of the investments is staggering - in Ordos, Inner Mongolia (one of several coal-rich areas in the province), 21 projects have been started with a total investment of 73.89 billion RMB (over U.S. $\$ 900$ billion) (Zhang, 2010). While at least two of these are coal to oil projects, the others are not and will produce a range of products.

Profit potential likely obscures or discourages attention to the potential negative impacts associated with coal to oil development. For example, Inner Mongolia and Ningxia are two of China's most arid provinces and both are in close proximity to the Yellow River. But rather than aridity and water scarcity acting as obstacles, the provinces 
are instead seen as ideal locations for coal to oil development. According to Zhang Wenjiang, chairman of Shenhua-Ningmei, "Ningxia is not only rich in coal but also in water and power supply, which are all important for the successful development of an indirect coal-liquefaction project" (Qi, 2006). In reality, Ningxia is one of the most watershort and arable land-poor regions of China, with per capita annual water resources just one half the Chinese national average. These two factors, the general aridity of the provinces and their proximity to a river that is already stretched thin in terms of water depletion, are viewed as negative attributes by the central government policymakers who would be left to contend with the negative consequences associated with greater stress on water resources. But for the companies urging coal to development, these challenges are arguably viewed from a perspective that prioritizes profitability over concerns about social unrest or environmental displacement.

\section{A 2010 report from the Pew Center on Global Climate Change summarized the} profit motive in coal to liquids projects, saying

These efforts to develop CTL are mainly driven by market forces and governmental policies. First, large coal-mining companies have become more interested in liquid fuels, other coal chemicals, and electricity businesses, which are more profitable than coal-mining alone. There are also a growing number of such companies that have gained the capability to enter the coal-chemical business because of a government policy that encourages the merger of traditionally small coal mines. Another factor is that their efforts are encouraged and supported by the local governments, which can expand their tax base and retain more profits from large coal-mining companies after the central government transferred their ownership to them in the 2000s. High oil prices worldwide in recent years also played a significant role. (Sun, 2010)

It is unsurprising that China's Shenhua Group has taken the lead in coal to oil and has been able to move ahead with two large projects. Shenhua is the largest key state- 
owned coal company in China and produces ten percent of China's coal output. Shenhua started coal production in 1995 under direct control of the State Council, and remains a vertically integrated firm that coordinates with four ministries and six provincial governments (Peng, 2009). Shenhua is a powerful, highly-connected company that has direct access to China's leading officials. Shenhua may yet reach its ambitious goals for synthetic oil production, but given the uncertainty in Beijing over the future of the coal to oil industry, the opportunity to move ahead with two projects with a total investment of over US 10 billion shows it has considerable support in at least some branches of the government. Likewise, the Yitai Group is considered China's most successful private coal mining enterprise, and "With strong support from the Inner Mongolia government, Yitai is able to expand its business to dedicated short distance coal railways, coal chemicals including CTL pilot plant and pharmaceutical business" (Tu, 2010). China's Lu'an Group and Yankuang Group are also powerful players. Given that each of these companies is a champion of provincial level governments, it is likely that they bring considerable economic and political clout to their negotiations with the NDRC and NEA over which projects will proceed and the types of targets and policies to be established for the industry.

I believe this study supports the conclusion that private companies have made efforts to influence the debate about coal to oil in China. Though it is difficult to quantify the effectiveness of those efforts, this study supports the general consensus that energy companies are important actors in the policy process, that they actively seek to shape policy, and that they can be counted on to pursue their own interests even if those 
interests are potentially in conflict with larger national interests. In this respect, there is an interesting parallel with the drive to develop a coal to oil industry that took place in the United States in the first half of the last decade (2000-05. As in China, coal-rich states and energy companies lobbied aggressively for national support of coal to oil development and featured the narratives of energy security and energy independence prominently in their arguments. These lobbying efforts were fiercely resists by environmental groups and others who questioned the degree to which coal to oil could enhance America's energy security and whether the incremental reductions in energyimport reliance were worth the considerable costs, both financial and environmental. In the end, those opposed to coal to oil development in the U.S. prevailed, preventing the federal government from enacting policies or legislation that would jumpstart the industry in the U.S.

In China, where there is no formal system of lobbying that affects policy, efforts from industry or environmental groups to influence coal to oil policy have taken different, less visible, and less direct forms. Nonetheless, given China's recent attempts to halt or slow coal to oil development, it is noteworthy that the results produced by two political systems different in structure and process appear to be at similar places in the ongoing debate regarding coal to oil development. This is a topic that is worthy of future research and comparative analysis. 


\subsection{China’s Energy Policymaking Process}

One of the findings of this study is that important decisions related to the coal to oil industry in China have essentially been forced onto the central government by the activities of the private sector. Driven by China's recent and intense interest in energy security, its growing demand for oil, and rising energy costs, powerful mining and energy companies, both domestic and international, have taken advantage of a window of opportunity for development of coal to oil projects and have done so in a compressed period of time between 2002 and 2009. At the same time, by giving Shenhua its blessing to develop the world's largest direct coal to oil project and encouraging investment in socalled clean coal technologies, China's government seemed to have signaled to companies that the time was right for large-scale investment in coal to oil projects projects that would not only enhance China's energy security, but would also go hand in hand with profit motives. As mentioned above, the lack of political support for coal to oil in the U.S. has largely prevented the industry from developing. But in China, it has taken an act of political will simply to slow the industry's development . Many of the economic and political barriers to coal to oil development present in the US are absent or less constraining in China, leading companies to announce projects and in some cases begin them without Beijing's complete support or approval (although many of the projects probably had local government approval). The government has had little choice but to react to new developments on the ground, and make ad hoc decisions about how to do so. The ad hoc policy decisions made over the past four years have been incremental, ranging from: (1) the original 2006 announcement that only projects above a certain size 
would be allowed to proceed, (2) to the call to halt all but two projects, (3) to the recent announcement that no new projects would be built for at least three years. The government has not acted as the lead voice on the issue, nor has it tried to clearly define what the industry will look like in five, ten or fifteen years.

This study also supports the conclusion that China's energy policymaking process is protracted and that most policies are shaped over longer periods of time. For the reasons discussed above as well as other domestic challenges, such as conflicts among bureaucracies, local governments, and powerful energy companies, it has been difficult for the Chinese government to make concrete decisions about the future of this industry. While I believe there are certain benefits to this slow style of policymaking, there is also reason to believe that outside of the directives that have been discussed, the government has struggled in its attempt to craft long-term policies and plans for the industry. Evidence of this can be found in the extremely slow progress of the government in drafting the Medium- and Long-Term Plan for Development of the Coal Chemical Industry, originally released in draft form in 2006. More than four years later, the plan has yet to be finalized despite numerous meetings, hearings, and indications that it was nearing completion. In 2006, 2007, and again in 2008, the NDRC announced that its consultations on the draft plan had in principle been completed and that it would aim to release the draft by 'year's end.' The same was said in 2009. At that time, commentators attributed the reasons for the delay to the "discrepancy of comments from different interest groups" (China Chemical Report, 2009). 
Thus, while the complexity of the issue and large number of variables involved has slowed decision making, it is also likely that there have been protracted negotiation between stakeholders. From this perspective, it is possible that by choosing to allow five coal to oil projects to proceed, the government sought to strike bargains between those in favor of development and those opposed to it. All of the coal companies moving ahead with coal to oil projects in China are among the largest in the country, and the projects are distributed among the four largest coal producing provinces in China, an indication that certain companies and provinces are being treated favorably as a way to placate key mining interests. This is a subject worthy of further study.

It is also likely the large number of government bureaucracies that influence the formulation of energy policy have differing views on whether or not coal to oil should be developed, magnifying the problems created by the absence of a dominant energy policymaking institution in China. When China announced the creation of a National Energy Commission to formulate a national energy strategy in January 2010, twenty bureaucracies were given a seat at the table, including a range of stakeholders such as the Ministry of Science and Technology, the State Administration of Taxation, the Ministry of Water Resources, and the Ministry of Environmental Protection. While all of these ministries have a role to play in helping the country create a coherent energy strategy, differences of opinion are inevitable as each jockeys for power and status within the government. In the end, it is the National Energy Administration and the National Development and Reform Commission that exert the most influence over energy policy in China; balancing the needs and interests of so many bureaucracies can only complicate 
an already daunting mandate. The number of conflicting statements about coal to oil I have outlined supports previous observations that the relatively weak institutions governing the energy sector make policymaking more difficult and that bargaining is likely part of the policymaking process.

Interestingly, in spite of obvious flaws and challenges to energy policymaking and resource management in China, I believe that the government's style of reactionary, ad hoc policymaking, at least in the case of the coal to oil industry, is both rational and sensible. In fact, I believe it is a perfectly logical response to the situation China faces in relation to this industry; that is, by muddling through for a period with pronouncements about what not to do, rather than directives about what to do, Beijing is providing itself with valuable decision making time and space in order to observe the evolution of a number of critical variables that will inform its decisions on the future of coal to oil. As discussed below, because so many variables must be included in the decision making process of energy policymakers in Beijing as they weigh the advantages and disadvantages of large-scale coal to oil development, this approach may in the end allow Beijing to formulate more effective, coherent policies for the industry.

The list of variables is that will influence the fate of the coal to oil industry is long and complicated, includes both domestic and international factors, and contains a large number of unknowns. The energy efficiency, water consumption, and overall resource needs of the projects have been presented but cannot be precisely known without more demonstrations and pilot projects. The economic viability and profitability of the industry is uncertain and depends on range of domestic and international factors. The technologies 
themselves, with the exception of Sasol's indirect coal to oil technology, have yet to be proven on a large scale and will need time to be perfected. A downstream distribution infrastructure will be needed in order to monetize the liquefied products. China's energy outlook is changing as new technologies like wind, solar, and nuclear energy are implemented widely, and changes in the transportation sector, such as the evolution of natural gas or electricity powered vehicles, may change the landscape further. The world has yet to agree on a climate change regime, which may include a carbon tax that penalizes carbon intensive fuels such as coal while incentivizing the use of cleaner forms of energy. The price of oil has shown extreme volatility in the past four years, with a fierce debate underway about whether or not global oil supplies are on the verge of reaching peaking. Last but not least, the global geostrategic environment and the future of US-China relations, looking forward over the next decade, is uncertain.

The combination of these issues and how they unfold in the coming years will determine the utility and viability of coal to oil technologies, But at the moment too little is known for China to be able to craft a long-term coal to oil development plan that accounts for each possible outcome or combination of outcomes. From this perspective, developing a handful of projects that use different technologies while taking a wait and see approach is not only rational, it makes more sense than rushing into a decision that, as I have shown, will have significant implications for China's environment.

In the coming years, when more is known about the complex issues involved, a more "coherent" policy for coal to oil can be established. In the meantime, China can still develop the capacity to develop a coal to oil industry without taking it to scale, thereby 
preparing the industry to rapidly expand future production as conditions warrant. In Chinese language articles, this thinking is characterized by the use of the term “technology reserve" (jishu ku or jishu chubei), a term that I believe captures the government's current way of thinking about coal to oil. As Zhou Dadi put it, "All countries have taken coal liquefaction as a technology reserve. I'm not against having such technology and developing it to a certain scale." If China is not sure to what extent it may need to rely on coal to oil technologies in the future, it makes sense to develop the industry on a limited scale today, thereby minimizing risks and potentially negative impacts while gaining a new and potentially valuable capability.

\subsection{Conclusions}

China's emerging coal to oil industry provides an excellent example of both the complexity of the energy policymaking environment in China and the difficult choices and tradeoffs that policymakers must make as they pursue divergent or even conflicting goals. In this study, there are two primary sources of tension that policymakers must contend with. The first is between those who would push for large-scale coal to oil development and those who oppose it, while the second tension is between the pros and cons of large scale development. Within the first tension, the actors involved include energy and mining companies, provincial and local officials and stakeholders, various bureaucracies within the government, the military, and, to a lesser degree, those who would potentially suffer as a result of development, such as rural farmers. Within the second tension, issues to be factored into the equation when determining the utility and 
ultimate value of coal to oil development include energy security, economic development and profit potential, coal resource impacts, water resource impacts, environmental implications (i.e. carbon emissions), the viability of the region's agricultural activities (which touches on issues of food security), and the opportunity to develop advanced energy technologies and Chinese intellectual property.

In the end, it is up to those in charge of establishing and enforcing China's energy policies and managing the energy sector who must not only take into account the costs and benefits of coal to oil development, but also contend with the various industry, provincial, and institutional actors who have their own vested interest in seeing the industry develop in a certain direction. At the same time, the equation for valuing the different factors involved, such as energy security or water resources, will continue changing as China's domestic and international circumstances involve. Just as a sudden oil shock or escalation in tensions between the U.S. and China could push China to add increasing value to energy security, and by extension the coal to oil industry, so could an extended drought that leads to social unrest in north China lead to coal to oil development falling out of favor.

Ultimately, this is why China's lack of a strong, well-staffed energy institution, such as a Ministry of Energy, is a glaring weakness in the country's energy policymaking apparatus, and is arguably why Chinese policymakers have been left to take a reactive, ad hoc approach to managing the industry's development. Given the high stakes involved, in terms of development costs, resource impacts, and environmental implications, it is essential that decisions about the future of this industry be made on the industry's merits 
alone, not on the interests or influence of the stakeholders involved. As discussed, I believe the government is currently managing tensions and balancing competing interests relatively well given the circumstances. But in the future, managing these tensions will likely grow harder, not easier, and will test the central government's ability to formulate and enforce energy policies.

This study makes three main contributions. First, it provides a detailed overview of the evolution of China's coal to oil industry, describes in depth the specific resource and environmental issues that would be affected by the industry's development, and provides examples of how those issues are being accounted for to varying degrees. Second, this study provides a framework for understanding why China's coal to oil industry has evolved the way it has, and makes sense of the confusing, often contradictory nature of project announcements and policy statements emanating from China in relation to this industry. Third, this study supports the conclusions of those who argue that China's energy policymaking process is not necessarily top-down, authoritarian in conduct, or even coherent, but rather that the process is complicated, messy, and ridden with bargains, compromises, and competition among stakeholders.

\subsection{The Future of Coal to Oil in China}

It is difficult to predict whether or not China will develop the capacity to produce 30 or 40 million tons per year of synthetic oil, or whether it will be able to replace close to ten percent of its oil imports with domestic liquefied coal. As described above, numerous factors that are as yet unclear will determine the fate of the industry and 
whether or not the central government is willing to shoulder the considerable environmental and resource burdens associated with the industry. In Appendix A, I outline three possible development scenarios for China's coal to oil industry, offer my view on which scenario is most likely, and discuss in depth some of the factors that will influence the industry's development.s

\subsection{Implications of Coal to Oil in China and Beyond}

The prospect that China develops its coal to oil industry slowly and deliberately, and that it mitigates the negative externalities associated with the industry by using CCS and implementing more efficient irrigation practices, leads to modest negative consequences for development of the energy sector on Chinese society as a whole. In addition to energy security gains, by attracting billions of dollars of investment in China's underdeveloped interior provinces, coal to oil projects can help stimulate economic growth and potentially provide opportunities for those relying on subsistence farming to join China's modern economy. For example, it is estimated Ningdong coal chemical base in Ningxia will create 30,000 jobs and will increase local incomes by 18 billion RMB per annum by 2020 (Sexton and Li, 2008). Developing Chinese technologies that could one day be exported could also benefit China's economy, and simply by taking on challenging projects like Shenhua's direct coal to oil project China builds engineering and technical capacity, gains experience in developing advanced technologies, and advances its ability to innovate. 
For the rest of the world, two of the potential positives emanating from China's coal to oil activities are the important technological insights gained from the Shenhua CCS program and coal to oil's capacity to enlarge the global energy pie. China and the world will reap significant benefits from the knowledge and learning gained through Shenhua's efforts to develop CCS capabilities associated with the Inner Mongolia project. The CCS project under development will be the largest in the world and currently there are few other projects of comparable scale underway as problems related to cost, liability, and risk exposure discourage developed countries from being first movers in developing CCS. With the knowledge gained from the Inner Mongolia CCS project, China could become a world leader in CCS technology while also providing other countries with important know how, such as how large volumes of compressed carbon dioxide react when stored in different geological formations. Given that the world remains heavily reliant on coal, that CCS is the only conceivable method for mitigating the carbon emissions associated with coal use, and the imperative to reduce global carbon emissions, advances and knowledge about CCS gained through Shenhua's activities are extremely valuable.

Similarly, if China were to eventually produce one million bpd of synthetic oil from coal (50 mta), this would be equivalent to boosting global oil production over one percent (current global oil production is approximately $85 \mathrm{mbd}$ ). While not a dramatic increase, by augmenting domestic oil production China's demand for oil from international markets would decrease pressure on global supply pressures.

Potential benefits aside, there are many reasons to be doubtful, and even pessimistic, that coal to oil will be a net benefit for China, and in my opinion the potentially negative 
consequences of developing a large scale coal to oil industry outweigh the potential benefits. The CCS technologies China intends to use to mitigate coal to oil's carbon emissions are far from proven, are prohibitively costly, and likely won't be applied on a scale large enough to fully offset the emissions released in the coal conversion process, especially if the industry is taken to scale. Likewise, it is highly questionable and probably unlikely that the promised advanced irrigation technologies will materialize and offset as much water as intended, or that those who rely on water for irrigation (and are already marginalized) in China will be treated fairly, or adequately compensated, for the irrigation water lost to coal to oil development. And by putting enormous pressure on China's coal resources, coal to oil development runs the risk of prematurely depleting China's domestic reserves and leading to either energy shortages or increased coal imports from countries such as Indonesia and Australia.

In short, the coal to oil industry, if brought to scale, has the potential to create social unrest by depriving rural farmers of water, and to worsen the living conditions and poverty levels of those on the margins of large projects. The outlook for China's water resources, especially in the densely populated north and north China plain, is already dire. Developing an industry that will increase water consumption by 100, 200, or even 500 million tons per year in China's most water-challenged region is a dangerous proposition. Were China to experience massive water shortages in the North China Plain or other areas on the banks of the Yellow River, the negative economic impact of unrest and migration, and potentially massive increases in grain and food imports, would be felt beyond China's borders. For these reasons and others, China would be wise to proceed 
slowly and cautiously as it experiments with coal to oil technologies; ultimately it may have to face the prospect of abandoning the effort completely or keeping production levels small.

Still, it is worth reiterating that coal to oil only makes up a small portion of China's larger coal to liquids industry, and that other areas of the coal to liquids industry are far more developed and growing more rapidly. As described, all of these coal chemical process are very similar in terms of greenhouse gas emissions, water consumption, and coal consumption. While I am in one sense heartened by China's restraint in developing coal to oil, I am aware that China's coal to liquids industry may already have an environmental and resource impact that is cumulatively as great as a large-scale coal to oil industry. It is beyond the scope of this study to draw definitive conclusions about the resource and environmental impact of China's larger coal to liquids industry, or its importance and contribution to China's energy security, but the rapid development of the coal to liquids industry should be a source of great interest and concern for those researching China's sustainable development. If this study serves one larger purpose, it is to encourage other researchers to broaden the scope of this research project on China's coal to oil industry to include coal to liquids in general.

Finally, as touched on previously, China's coal to oil industry is not without strategic implication. The history of coal to oil is one based on and founded in war. Militaries are traditionally large consumers of petroleum, and domestic oil production is prized as a means to fuel trucks, tanks, and jets in the event of conflict or the disruption of oil imports. One of coal to oil's unique capabilities is that it can be upgrade rather easily to 
jet fuel, a valuable commodity often in short supply in times of war. Germany successfully met a high percentage of its jet fuel needs with coal during WWII, and in recent years the United States has successfully flown a variety of Naval and Air Force jets on fuel derived from coal (Guardian, 2009). China has been working to develop the capability to make fighter jet-ready fuel out of coal, and it has recently had several breakthroughs in this respect (Science and Technology Daily, 2009). While not necessarily a threat, this is a noteworthy military capability with potential implications for the U.S.

\subsection{Final Thoughts}

The title of this study poses a question: which phrase best describes the development of China's coal to oil industry, "crossing the river by feeling the stones" or "scientific development?" Before answering this question, it is helpful to provide background on the two phrases and their meanings in the Chinese context. The term "crossing the river by feeling the stones" (mozhe shitou guo he) is a Chinese proverb that means to "explore one's way carefully.” It was used by Deng Xiaoping in the 1970s to describe China's approach to economic liberalization through implementation of partial reforms in a gradual, experimental manner, with proven successes expanded on. The term "scientific development" (kexue fazhanguan) refers to the current official guiding socio-economic philosophy of the Communist Party of China, which was ratified into the CPC's constitution in October 2007 under the leadership of President Hu Jintao. The concept stresses improving the socialist market economy and incorporating science and 
technology into China's future development, but it also emphasizes a shift away from economic growth at all costs to a development model that better incorporates balanced development between rural and urban areas, social welfare, and environmental protection, with the end goal of creating a harmonious society.

Although I have the framed the question as an either-or proposition, I believe the Chinese government's approach to coal to oil management incorporates the meaning of both phrases. The government has taken a gradual, experimental approach to coal to oil development and is preparing to expand on successes while minimizing the risks of failure. In trying out different technologies to gauge their relative merits and shortcomings, it can be argued the government is using an approach similar to the one it relied on to gradually open China's economy to market forces through the use of Special Economic Zones and localized policy experiments. This is precisely the approach that Deng described as "crossing the river by feeling the stones."

At the same time, China recognizes that there are adverse consequences to developing coal to oil projects, namely greenhouse gas emissions and a large demand for water in arid environments. Such thinking reflects growing awareness by the central government of sustainable development and "social harmony." I suspect that in the 1990s, had China been facing today's predicament of growing oil import dependence and skyrocketing energy costs, it would not have hesitated to rapidly develop a large-scale coal to oil industry, regardless of the potential environmental and social consequences. Today, however, China is more concerned about the environmental and human security costs of development than at any time since the founding of the People's Republic of China, and I 
believe this theory of "scientific development" is reflected in the government's reluctance to offer unqualified support for coal to oil development, at least without knowing more about its impacts and whether the balance sheet adds up.

This thesis has tried to shed light on the challenges and decisions facing China's leadership and energy bureaucracies as they attempt to govern China's emerging coal to oil industry. China's population, resource geography, rapid economic growth, and social inequities combine to create what must at times seem to energy policymakers like an intractable set of problems. As it works to create effective energy policies that balance and address these competing needs and demands, China's leadership confronts problems related to economic and political decentralization, powerful energy companies, and weak energy institutions. China's coal to oil industry embodies and brings together many of these challenges and provides a new opportunity for evaluating and observing how China's energy policies, and the policymakers responsible for them, attempt to face the country's future. Observers are correct to point out the weaknesses and shortcomings of China's energy policies and the governing environment in which they are made. But they would be wrong to overlook the successes those same policies and institutions have had in spite of the array of problems they face.

It is too early to render a final verdict on China's management of the coal to oil industry. In the future, policymakers may be overwhelmed by the drive for profit and the pursuit of energy security, giving in to massive coal to oil development whatever the costs. But for now, the officials in charge of overseeing China's energy sector, and the officials overseeing them, seem to recognize that energy security is no substitute for 
environmental security, or human security, and they are choosing their steps carefully. If nothing else, this is a development worth noting. 


\section{References}

ADB (Asian Development Bank). 2009. Energy outlook for Asia and the Pacific. Phillipines: ADB (October).

Aden, Nethaniel, David Fridley, and Nina Zheng. 2009. China's coal: Demand, constraints, and externalities. California: Lawrence Berkeley National Lab. http://china.lbl.gov/sites/china.lbl.gov/files/LBNL-2334E.pdf (accessed July 10, 2009).

Andrews-Speed, Philip. 2004. Energy policy and regulation in the People's Republic of China. London: Kluwer Law International.

Asia Times Online. 2006. Boost for China's coal-chemical sector. December 21. http://www.atimes.com/atimes/China_Business/HL21Cb01.html (accessed May 10, 2010).

Bartis, James, Frank Camm, and David S. Ortiz. 2008. Producing liquid fuels from coal: Prospects and policy issues. Santa Monica, CA: The Rand Corporation. http://www.rand.org/pubs/monographs/2008/RAND_MG754.pdf (accessed June 2009).

Biopact blog. 2006. Chinese top official dismisses coal-to-liquids as irresponsible and inefficient. October 27. http://news.mongabay.com/bioenergy/2006/10/chinesetop-official-dismisses-coal-to.html (accessed June 02, 2010).

BP. 2010. BP statistical review of world energy. www.bp.com/statisticalreview (accessed May 1, 2010).

Bradsher, Kenneth. 2005. Are fuel shortages in China man-made? The New York Times. August 18. http://www.nytimes.com/2005/08/17/business/worldbusiness/17ihtfuel.html (accessed January, 2010).

Branigan, Tania. 2008. One-third of China's Yellow River 'unfit for drinking or agriculture.' The Gaurdian. November 25. http://www.guardian.co.uk/environment/2008/nov/25/water-china (accessed June 20, 2010).

China Central Television (CCTV). 2009. Shenhua begins new trial of coal to oil projects. Print version. September 21. http://english.cctv .com/program/bizchina/20090921/101571.shtml (accessed April,2010). 
China Chemical Industry News. 2006. Long-term development plan of coal chemical industry is expected to be announced within the year [meihuagong chanye zhong chang qi fazhan guihua gouwang nian nei gong bu] (in Chinese). December 21. http://stock.stockstar.com/GA2006122100405521.shtml\# (accessed June 02, 2010)

China Chemical Report. 2008 China coal chemical review. February 6. http://icct.ecust.edu.cn/list.php?id=17\&newsid=290 (accessed June 16, 2010).

China Coal Resource. 2009. Yankuang to invest 13.5 bln in CTO project. February 4. http://en.sxcoal.com/NewsDetail.aspx?cateID=167\&id=20330\&keyword=diesel (accessed June 15, 2010).

China Daily. 2008. China's coal liquefaction phase cools off. September 19. http://www.chinadaily.net/bizchina/2008-09/19/content_7043240.htm (accessed June 01, 2010).April 9

Coal Net. 2007. When will the medium- and long-term plan for the coal chemical industry be announced? [meihuagong chanye zhong chang qi fazhan guihua he shi chu tai?] (in Chinese). http://www.sei.gov.cn/Show Article2008.asp?ArticleID=111980 (accessed June $10,2010)$.

Chu, Huaijun. 2008. The meaning and future of China's coal to oil program [zhongguo meizhiyou xiangmu de yiyi yu weilai] (in Chinese). Reform and Opening, no. 4: 15-16. Cole, Bernard D. 2006 Chinese naval modernization and energy security. National Defense University (July 20).

Creamer, Martin.2008. Sasol's CTL project in China ahead of South Africa's CTL project. Mining Weekly. October 24.

Cunningham, Edward. 2007. China's energy governance: Perception and reality. The Audit of Conventional Wisdom [Massachusetts Institute of Technology], 07-04 (March). http://web.mit.edu/cis/pdf/Audit_03_07_Cunningham.pdf (accessed July 12, 2009).

DeWit, Andrew, and Jonathan Watts. 2009. Clean coal and the two faces of China's coal industry. The Asia-Pacific Journal 51, 2-09 (December). http://www.japanfocus.org/-Andrew-DeWit/3271 (accessed June 01, 2010). 
DOE (U.S. Department of Energy). National Energy Technology Laboratory. 2006. Emerging issues for fossil energy and water. Prepared by the Office of Systems, Analyses and Planning. Open-file report, U.S. Department of Energy. http://www.netl.doe.gov/technologies/oilgas/publications/AP/IssuesforFEandWater.pdf (accessed July 2009)

2009. Readout of Secretary Chu meetings on carbon capture and sequestration and state grid. Press release (July 16). http://www.energy.gov/news2009/7651.htm (accessed July 16, 2009).

Energy Information Administration (EIA). 2009. Country analysis briefs: China. http://www.eia.doe.gov/emeu/cabs/China/Background.html (accessed April 5, 2010).

Dow Jones. 2010. China has postponed review of Sasol-Shenhua CTL project. March 5. www.zoomchina.com.cn/new/content/view/67364/81/ (accessed June 10, 2010).

Downs, Erica. 2006. China. The Brookings Foreign Policy Studies Energy Security Series, December. http://www.brookings.edu/fp/research/energy/2006china.pdf (accessed November 10, 2009).

2007. China's Energy Bureaucracy: The Challenge of Getting the Institutions Right. In Shaping China's Energy Security: The Inside Perspective, ed. Michal Median,64-89. Paris: Asia Centre.

Ebel, Robert E. 2005. China's energy future: The middle kingdom seeks its place in the sun.Washington, DC: The Center for Strategic and International Studies.

Economic Information Daily. 2007. Coal replacing oil strategy comes to the surface [meitan tidai shiyou zhanlue fuchu shuimian] (in Chinese). September 18. http://finance.ce.cn/macro/main/sys/gz/ny/200709/18/t20070918_12613609.shtml (accessed June 20, 2010).

Energy Watch Group. 2007. Coal: Resources and future production. Series No 1/2007 (March).http://www.energywatchgroup.org/fileadmin/global/pdf/EWG_Report_C oal_10- 07-2007ms.pdf (accessed June 1, 2010).

Engineering News. 2009. Sasol to integrate carbon capture into China project's design. October 23. http://www.engineeringnews.co.za/article/sasol-to-integrate-carboncapture-into-china-projects-design-2009-10-23 (accessed June 20, 2010).

Forbes. 2005. China considers 24 bln usd investment in coal-to-liquids technologies. September 27. http://www.forbes.com/feeds/afx/2005/09/27/afx2247877.html (accessed June 1, 2010). 
Gao, Xudong. 2009. Understanding key features of the TD-SCDMA adoption process in China. Paper presented at the NBR conference on China's technical standards and innovation policies, Beijing, China, October 13.

Giordano, Mark, Zhongping Zhu, Ximing Cai, Shangqi Hong, Xuecheng Zhang and Yunpeng Xue. 2004. Water Management in the Yellow River BasinL Background, current critical issues and future research needs." Comprehensive Assessment Research Report 3.

Gibson, P. 2007. Coal to liquids at Sasol. Presentation, Kentucky Energy Security Summit (October 11). http://www.caer.uky.edu/podcast/GibsonKESummitOct2007r.pdf (accessed October, 2010).

Goodman, Peter S. 2005. Big shift in China's oil policy. Washington Post. July 13. http://www.washingtonpost.com/wpdyn/content/article/2005/07/12/AR20050712 01546.h tml (accessed February 5, 2010).

Greencar Congress. 2009. China's Yitai Group CTL plant produces diesel and naphtha in trial run. March 26. http://www.greencarcongress.com/2009/03/chinas-yitaigroup-ctl-plant-produces-diesel-and-naptha-in-trail-run.html (accessed June 20, 2010).

Guardian. 2009. U.S. Air Force drops plans to build coal-to-liquid fuel plant. January 30. http://www.guardian.co.uk/world/2009/jan/30/air-force-liquid-coal-fuel (accessed June 10, 2010).

Guth, Joanne, and Melissa Ginsberg. 2004. Energy use in China: Trends in oil demand and imports. International Economic Review, November/December. http://web.rollins.edu/ tlairson/asiabus/chinaenergy.pdf (accessed September 30, 2010).

Hawkins, David. 2006. Testimony before U.S. Senate. Full Committee Hearing on Coal Liquefaction and Gasification. April 24.

Höök, Mikael, and Kjell Aleklett. 2009. A review on coal-to-liquid fuels and its coal consumption. International Journal of Energy Research (July 30). http://www3.interscience.wiley.com/journal/122525697/abstract?CRETRY=1\&S RETRY $=0$ (accessed December, 2009).

$\mathrm{Hu}$, Weiping. 2007. Introduction to the $11^{\text {th }}$ five-year plan on energy development. Presentation, US-China Oil and Gas Forum, San Francisco, CA. September 10. http://www.uschinaogf.org/Forum8/monday/2-Hu\%20WeipingNDRC\%20Topic11\%20five-year\%20plan\%20English.pdf (accessed March 10, 2010) 
IEA (International Energy Agency). 2006. Coal to liquids: An alternative oil supply? IEA Coal Industry Advisory Board Workshop (November 2).

www.iea.org/work/2006/ciab_nov/workshopreport.pdf (accessed January, 2007).

2007. World energy outlook 2007: China India insights. France: International Energy Agency.

2009. Cleaner coal in China. France: International Energy Agency.

Innovation Center for Energy and Transportation (iCET). 2008. Background and strategy of Chinese low carbon fuel standards and policies. Development Research Center of the State Council. December.

http://www.icet.org.cn/en/Programs/Fuels/Reports_en.html (accessed March 1, 2010).

Kim, Jih-Un. 2002. Looking into a Microcosm of China's Water Problems: Dilemmas of Shanxi - A High and Dry Province. China Environment Series, Issue 5 : 59-62.

Kong, Bo. 2005. An anatomy of China's energy insecurity and its strategies. Pacific Northwest National Laboratory PNNL-15529 (December). http://www.pnl.gov/main/publications/external/technical_reports/PNNL15529.pdf (accessed August, 2009).

2006. Institutional Insecurity. China Security, Summer: 64-88.

2010. The geopolitics of the Myanmar-China oil and gas pipelines. Paper presentation at NBR's Energy Security Conference, Washington, DC. May 4.

Lester, Richard K., and Edward S. Steinfeld. 2006. China's energy policy: Is anybody really calling the shots? Industrial Performance Center Working Paper Series [MIT] (January).

Lewis, Joanna. 2005. From technology transfer to local manufacturing: China's emergence in the global wind power industry. PhD diss., University of California, Berkeley.

Lieberthal, Kenneth, and Michael Oksenberg. 1988. Policy making in China: Leaders, structures, and processes. New Jersey: Princeton University Press.

Lieberthal, Kenneth, and Mikkal Herberg. 2006. China's search for energy security: Implications for US Policy. NBR Analysis [The National Bureau of Asian Research] 17, no.1 (April). 
Lieberthal, Kenneth. 2009. U.S.-China clean energy cooperation: The road ahead. Brookings Policy Brief 09-05 (September).

Lim, Le-Min, and Loretta Ng. 2004. China may spend \$10 bln to turn coal into auto fuel (Update1). Bloomberg. November 21.

http://www.bloomberg.com/apps/news?pid=newsarchive\&sid=a5EQh6QBQGtY \&refer=asia-redirectoldpage (accessed June 10, 2010).

Lu'an Company website. In Chinese.

http://www.cnluan.com/Article/ShowArticle.asp?ArticleID=6839 (accessed May, 2010).

Madlala, Ollie. 2004. SA technology fuels China's large coal to liquids plans.

Engineering News. November 1. http://www.engineeringnews.co.za/article/satechnology-fuels-chinas-large-coaltoliquids-plans-2004-11-01 (June 10, 2010).

Marion, Pierre. 2008. The current status of coal liquefaction technologies. Panorama 2008 [ifp]. http://www ifp.fr (accessed September, 2009).

Massachusetts institute of Technology (MIT). 2007. The future of coal: Options for a carbon-constrained world. Massachusetts institute of Technology. web.mit.edu/coal/The_Future_of_Coal.pdf (accessed December, 2007).

Meidan, Michal, ed. 2007. Shaping China's energy security: The inside perspective. France: Asia Centre.

Meidan, Michal, Philip Andrews-Speed, and Ma Xin. 2009. Shaping China's energy policy: Actors and processes. Journal of Contemporary China 18, no. 61 (September): 591-616.

Meng, Lei, Ju'e Guo, and Youmin Xi. 2008. Analysis on the acceptable scale and energy substitution effects of the coal conversion to oil projects in western China [xibu meizhiyou xiangmu kerongna guimo yu nengyuan tidai xaioging fenxi] (in Chinese). Forecasting 27, no. 4: 75-80.

Modern Power Systems. 2005. China to clamp down on illegal plants. April.

Morrison, Wayne M. 2009. China's Economic Conditions. Congressional Research Service Report for Congress, 7-5700 (December 11). 
Morse, Richard, Varun Rai, and Gang He. 2009. The real drivers of carbon capture and storate and implications for climate policy. Program on Energy and Sustainable Development Working Paper 88 [Stanford University] (August). http://iisdb.stanford.edu/pubs/22621/WP_88_Morse_He_Rai_CCS_in_China.pdf (accessed June 20, 2010).

Mu, Xuejiang. 2009. The reason America does not choose coal to oil [meiguo bu xuan meizhiyou de liyou] (in Chinese). Petroleum Vane (April 24): 80.

NDRC (National Development and Reform Commission). 2006. Notice on Enhancing Management of Coal Chemical Projects and Promoting Healthy Development of the Industry [guanyu jiaqiang meihuagong xiangmu jianshe guanli cujin chanye jiankang fazhan de taongzhi]. (In Chinese). July 7. http://www.sdpc.gov.cn/zcfb/zcfbtz/tz2006/t20060713_76450.htm (accessed June 2, 2010).

2008. Notice on some issues related to strengthening the management of the coal chemical industry [Guanyu jiaqiang meizhiyou xiangmu guanli you guan wenti de tongzhi] (in Chinese). August 4.

2009. Notice on reining in overcapacity and duplicated projects in some sectors, and guiding the healthy development of industries [guanyu yizhi bufen hangye channeng guosheng he chongfu jianshe yindao chanye jiankang fazhan ruogan yijian de tongzhi]. (In Chinese). September 29. http://www.gov.cn/zwgk/200909/29/content_1430087.htm (accessed February , 2010).

2009a. Notice on reining in overcapacity and duplicated projects in some sectors, and guiding the healthy development of industries: The fourth departmental news conference [guanyu yizhi bufen hangye channeng guosheng he chongfu jianshe yindao chanye jiankang fazhan ruogan yijian de tongzhi: di si ci bumen lianhe xinxi fabu hui] (in Chinese). December 31.

http://xwzx.ndrc.gov.cn/wszb/t20091230_322539.htm (accessed June 20, 2010).

Oil and Gas Journal. 2006. Watching the world: CTL helping coal advance. July 17. http://www.ogj.com/index/search.html?si=ogj+\&collection=ogj\&keywords=Watc hing+the+world $\% 3 \mathrm{~A}+\mathrm{CTL}+$ helping+coal+advance (accessed June 1, 2010)

Osnos, Evan. 2009. Green Giant. The New Yorker. December 21.

Pan, Liansheng. 2008. Coal chemical industry do be developed in a scientific way [jianchi kexue fazhan meihuagong] (in Chinese). Coal Chemical Industry 5, no. 138: $1-4$. 
Pan, Liansheng, Zhang Ruihe, and Zhu Cenghui. 2008. Some thoughts on China's development of coal-based energy and chemical products [dui woguo meiji nengyuan huagongpin fazhan de yixie sikao] (in Chinese). China Coal 34, no.5 (May): 64-72.

Peng, Wuyuan. 2009. The evolution of China's coal institutions. Program on Energy and Sustainable Development Working Paper 86 [Stanford University] (August). http://iis-db.stanford.edu/pubs/22612/PESD_WP_86.pdf (accessed June 21, 2010).

Qi, Wu. 2006. China cools down coal liquefaction. Asia Times Online. October 4. http://www.atimes.com/atimes/China_Business/HJ04Cb01.html (accessed January, 2010)

Reuters. 2008. China's oil demand growth to dip 2010-2020. April 8. http://uk.reuters.com/article/idUKPEK16930220080408 (accessed June 2, 2010).

2010. China yet to approve Sasol coal-oil scheme. June 21. http://www.miningmx.com/news/energy/China-yet-to-approve-sasol-coal-oilscheme.htm (accessed June 21, 2010).

Rosen, Daniel, and Trevor Houser. 2007. China energy: A guide for the perplexed. China Balance Sheet [Peterson Institute of International Economics] (May). Sasol. 2006. Sasol and Chinese sign landmark coal-to-liquids agreement. Sasol news centre. June 22.

http://www.sasol.com/sasol_internet/frontend/navigation.jsp?articleTypeID=2\&ar ticleId=14900002\&navid=4\&rootid=4 (accessed June 15, 2010).

Science and Technology Daily. 2009. Chinese Air Force oil research institute makes breakthrough in coal-based jet fuel [zhongguo kongjun mou youliao yanjiusuo mei ji penqi ranliao qude xin tupo] (in Chinese).

http://news.ifeng.com/mil/2/200908/0813_340_1299631.shtml (accessed June 21, 2010).

Sexton, John, and Pang Li. 2008. Shenhua coal-chemical base takes shape in Ningxia. China.org. July 21. http://www.china.org.cn/china/Ningxia/200807/07/content_15967894_2.htm (accessed June 01, 2010).

Shanghai Daily. 2008. Fuel shortage poses policy dilemma. June 5. http://www.china.org.cn/business/2008-06/05/content_15638613.htm (accessed December, 2009).

Shirk, Susan L. The political logic of economic reform in China. Los Angeles, CA: University of California Press. 
Sina. 2006. China's to spend one trillion to become a coal chemical industry power to help alleviate energy problems [zhongguo chizi 1 wan yi mouhua meihuagong daguo youzhu huanjie nengyuan wenti] (in Chinese). December 16.

http://gov.finance.sina.com.cn/zsyz/2006-12-18/95850.html (accessed May 30, 2010).

Spiegel, Peter. 2009. China orders 1.3 billion drought relief for wheat growers. Los Angeles Times. February 8. http://articles.latimes.com/2009/feb/08/world/fgchina-drought8 (accessed June 20, 2010).

State Council Information Office (China). 2007. White paper on energy. http://www.china.org.cn/english/environment/236955.htm (accessed April 20, 2010)

Steel Guru. 2008. Yankuang Group CTL project approved. January 12. http://www.steelguru.com/news/chinese_news/MzQyMjY=/Yankuang_Group_C TL_project_approved.html (accessed June 15, 2010).

Storey, Ian. 2006. China's "Malacca dilemma." China Brief [Jamestown Foundation] 6, no.8 (April 12).

http://www.jamestown.org/programs/chinabrief/single/?tx_ttnews\%5Btt_news\%5 $\mathrm{D}=31575 \&$ tx_ttnews\%5BbackPid\%5D $=196 \&$ no_cache=1 (accessed January 5, 2010).

Sun, Guodong. 2010. Coal in China: Resources, Uses, and Advanced Coal Technologies. Coal Initiative Reports White Paper Series [Pew Center on Global Climate Change] (March). http://www.pewclimate.org/docUploads/coal-in-chinaresources-uses-technologies.pdf (accessed March, 2010)

Sun, Hai, and Youmin Xi. 2009. Coal to oil industrialization: The path of China's future transport energy security strategy [meizhiyou changyehua: woguo weilai yunshu nengyuan anquan zhanlue de lujing xuanze] (in Chinese). Modern Management Studies, no.7: 5-8.

Sun, Qingyun. 2008. CTL development in China: Based on Shenhua CTL projects. Presentation, Congressional Noontime Briefing. April 24. http://files.asme.org/asmeorg/NewsPublicPolicy/GovRelations/21387.pdf (accessed December, 2009).

Swaine, Michael D. 2008. Managing China as a strategic challenge. In Strategic Asia 2008-09: Challenges and choices, ed. Ashley J. Tellis, Mercy Kuo, and Andrew Marble., 70-105. Seattle: The National Bureau of Asian Research. 
Tang, Hongqing. 2008. The scientific development of the coal chemical industry is our hope [kexue fazhan meihuagong shi women de xiwang] (in Chinese). Petroleum and Chemical Construction 30, no.5 (October): 10-17.

Tu, Jianjun. 2010. Industrial organization of the Chinese coal industry. Discussion paper prepared for the Program on Energy and Sustainable Development [Stanford University] (June).

http://www.emrg.sfu.ca/media/publications/China_Coal_Value_Chain_J.Tu_Draf t.pdf (accessed June 25, 2010).

Wang, Xiangkun. 2008. Considering alternative energy options: Coal to oil [tidai nengyuan kaoliang de xuanze: meizhiyou] (in Chinese). China Petroleum and Chemical Industry, no. 15: 12-16.

Wang, Yahua. 2003. "Water Dispute in the Yellow River Basin: Challenges to a Centralized System,” China Environment Series, Issue 6: 94-98.

Wang, Ying. 2006. Shenhua to build oil projects. China Daily. June 16. http://www.chinadaily.com.cn/bizchina/2006-06/16/content_618447.htm

Wang, Xuhui. 2010. Coal to oil: New life in the middle of controversy [meizhiyou: zhengyi zhong zaixian shenji] (in Chinese). China Energy Report (April 21). http://energy.people.com.cn/GB/11419714.html (accessed June 20, 2010).

2010a. What is the strength of Sasol's coal to oil? [Shasuo meizhiyou 'qiang' zai na?] (in Chinese). China Energy Report, no. 10 (March 29). http://paper.people.com.cn/zgnyb/html/2010-03/29/content_477011.htm (accessed June 15, 2010).

Williams, Robert H., and Eric D. Larson. 2003. A comparison of direct and indirect liquefaction technologies for making fluid fuels from coal. Energy for Sustainable Development 7, no. 4 (December): 103-129.

World Coal Institute. 2006. Coal: Liquid fuels. United Kingdom: World Coal Institute (October).

2009. Coal statistics. http://www.worldcoal.org/resources/coalstatistics/ (accessed June 1, 2010).

Wu, Zhong. 2006. China bets big on coal-to-oil projects. Asia Times Online. May 23. http://www.atimes.com/atimes/China_Business/HE23Cb06.html (accessed June $15,2010)$ 
Xiao, Xiangfeng. 2008. Cold thought about the enthusiasm for coal to oil [meizhiyou rezhong de leng sikao]. Chemical Engineering and Equipment [huaxue gongcheng yu zhuangbei], no. 9 (September): 108-111.

Xinhua News. 2006. Nation reins in fast growth of coal-to-liquids fuel projects. July 29. http://www.chinadaily.com.cn/bizchina/2006-07/29/content_652627_2.htm (accessed July, 2009).

2007. China may halt production of liquefied coal. June 10. http://news.xinhuanet.com/english/2007-06/10/content_6222209.htm (accessed May 30, 2010).

2007a. World's first coal-to-oil mass converter due to start operation this year. June 22. http://english.people.com.cn/200706/22/eng20070622_386664.html (accessed June 15, 2001).

2008. China's coal price caps are making energy shortages worse - analysts. July 30, 2008. Retrieved from

- 2009. China's coal-to-liquids projects buffeted by changing policy, economic environment. April 6. http://www.china.org.cn/business/200904/06/content_17559004.htm (accessed June, 2009).

2010. Shenhua-Sasol CTL project applies for NDRC approval. March 9. http://www.istockanalyst.com/article/viewiStockNews/articleid/3930365 (accessed June 10, 2010).

2010a. China's first carbon capture plant to start operation by year end. June 2. http://news.xinhuanet.com/english2010/business/2010-06/02/c_13329759.htm (accessed June 10, 2010).

Yang, Hong. 2010. Land and water use changes in the Yellow River basin and their driving forces. Presentation, Global Aspects of Water Research and Management in Large River Basins Workshop [Global Water Systems Project]. February 17-19. http://www.gwsp.org/65.html (accessed June 20, 2010).

Yardley, Jim. 2006. A Troubled River Mirrors China's Path to Modernity. The New York Times. November 19.

Yergin, Daniel. 1988. Energy security in the 1990s. Foreign Affairs 67, no.1 [Fall]. 2007. Energy independence. The Wall Street Journal. January 23. 
Yu, Hongyan. 2010. China becomes a net coal importer in 2009. China Daily. February 23. http://www.chinadaily.com.cn/bizchina/2010-02/23/content_9490004.htm (accessed March 10, 2010).

Zha, Daojiong. 2005. China's Energy Security and Its International Relations. The China and Eurasia Forum Quarterly3, no. 3: 39-54. 2010. Oiling the wheels of foreign policy? Energy security and China's international relations. Asia Security Initiative Policy Series, Working Paper no. 1 (March).

Zhang, Qi. 2008. Is it the end of the line for coal-to-oil in China? China Daily. October 9. http://www.chinadaily.com.cn/bizchina/2008-10/09/content_7090441.htm (accesed June 5, 2010).

Zhang, Yan. 2010. Coal to natural gas becomes new favorite: Inner Mongolia will process half of its coal locally [meizhitianranqi cheng xinhong: neimenggu yi ban meitan jiang jiude zhuanhua]. Workers Daily. February 11. http://huanbohai.huanbohainews.com.cn/system/2010/02/11/010604494.shtml (accessed June 16, 2010).

Zhang, Yangjian, Weida Xiang, Zhou Tao, and Lei Jiasu. 2009. The opportunities and challenges of coal to oil development [meizhiyou de fazhan jiyu yu tiaozhan] (in Chinese). Coal Economic Research, no.8: 6-8.

Zhu, Zhongping, Mark Giordano, Ximing Cai, and David Molden. 2004. The Yellow River Basin: Water accounting, water accounts, and current issues. Water International, Volume 29, no. 1 (March): 2-10. 


\section{Appendix A}

China's coal to oil industry will likely follow one of three scenarios between now and the year 2020. In the first scenario, the government does not actively support or promote coal to oil development; the Shenhua-Sasol project in Ningxia is never actually constructed (or a much smaller version of the planned project is built); the three smaller domestic projects develop to or slightly beyond the demonstration phase but never exceed one million tons per year; and Shenhua's direct coal to oil project in Inner Mongolia achieves operational success but does not expand beyond the first phase of development. In this scenario, China's coal to oil industry would produce between five and ten million tons of synthetic oil per year, making it boutique technology that generates some revenue and fuels some automobiles and airplanes, but is not a major contributor to China's domestic oil production or energy security.

In the second scenario, the five projects under planning or construction today reach their planned capacity or close to it, other projects are developed in places like Xinjiang or southwest China, and the total annual production reaches approximately 30 million tons of synthetic oil per year (or approximately 600k barrels of oil per day) in 2020. If China is consuming approximately 550 million tons of oil per year (or 11.2 million barrels per day) in 2020, as the Chinese Academy of Social Sciences projects (Reuters, 2008), this would mean the coal to oil industry is meeting approximately five percent of China's total demand and replacing approximately 8 percent of China's total imports. Clearly, this is not an insignificant amount, and if coupled with other oil 
replacement strategies, such as the use of biofuels and methanol derived from coal, China could potentially reduce its oil imports by 10 to 20 percent or more.

In a third scenario, China aggressively pursues coal to oil and eventually receives 30 million tons of production per year from Shenhua alone, with other companies like Lu'an and Yitai contributing between 20 to 30 million tons per annum. In this scenario, which was predicted by the US Department of Energy's Energy Information Agency, China would be producing approximately 50 million tons per year of synthetic oil by 2025 and possibly more than 60 million tons per year by 2030 (these volumes are highly unlikely by 2020 given the construction and development times of large projects). Were the industry to reach 60 million tons (approximately 1.2 million barrels per day) per year in 2030, synthetic oil would boost China's domestic production by over 40 percent (assuming China is producing $2.7 \mathrm{mbd}$ in 2030). While under no scenario is China able to eliminate its dependence on oil imports, under the second and third scenario it would be able to significantly boost domestic production and enhance its energy security through the use of coal to oil technologies.

Given the number of economic, environmental, and resource challenges created by a coal to oil industry that produces 30 or 60 million tons of synthetic oil per year, my estimate is that China in the year 2020 will be somewhere in the middle of scenarios one and two. While the externalities associated with the coal to oil industry are large enough to dissuade China from fully pursuing scenario two or three, several factors will combine to propel China past the projections for scenario one. First is the already large investments made in developing the coal to oil technologies and in building Shenhua's 
direct coal to oil plant in Inner Mongolia which, if it expands to phase two, will produce $5 \mathrm{mta}$ on its own. If the Sasol project goes ahead it will add an additional $3 \mathrm{mta}$. Thus, the three smaller projects under development would only need to produce an additional $7 \mathrm{mta}$ between them for China to reach $15 \mathrm{mta}$, or about 300k bpd. In December 2009, the NDRC estimated the capacity of announced projects as $40 \mathrm{mta}$, and as I've mentioned before it is difficult to know whether these projects are on the drawing board, undergoing feasibility studies, or under construction. Though I suspect most of them are only plans and studies at the moment, and the government has halted new projects for at least three years, should these projects proceed the industry's output could easily reach 20 mta by 2020.

Second, these companies and the coal industry as a whole have considerable influence in Beijing given their size, profitability, the large number of people they employ, and the importance of coal to China's economic development. They will likely lobby for allowing their projects to expand, especially if there is potential for large profits. Third, even if the volume of synthetic oil produced from coal does not significantly offset oil imports, there is important strategic value in boosting domestic production. China's domestic oil production is expected to fall from approximately $3.7 \mathrm{mpd}$ in 2006 to 2.7 mbd in 2030, and domestic oil production is extremely important to modern militaries who must be prepared, in a time of crisis, to meet their gasoline, diesel, and jet fuel needs without relying on oil imports, which may not be available. A coal to oil industry, even a relatively small one at $15 \mathrm{mta}$, would provide important reserve production capacity should oil imports suddenly slow or stop. 
There are, however, circumstances that may push China into pursuing a much more aggressive approach to developing the coal to oil industry. One would be a prolonged period of tight world oil supply that drives prices to unprecedented heights, immediately driving up the profitability of the coal to oil projects. The incentive would increase if these projects are actually able to produce gasoline or diesel at less than the equivalent of U.S. \$60-70 per barrel. As mentioned, between 2000 and 2008 global oil prices rose from $\$ 23$ to $\$ 145$ per barrel. If in the future global oil production begins to decline and new reserves are not brought on line quickly enough to keep pace with growing demand (a scenario that many predict is not far away), it is conceivable global oil prices will return to or even surpass the $\$ 150$ per barrel level and stay there indefinitely. The impact such a scenario would have on China's economy is enormous and would drive China to considerably ramp up coal to oil investment and production in response.

A second possibility is that China suddenly cannot buy oil on the free market, at any price, and is therefore unable to meet domestic demand. The resulting economic and political implications terrify the CCP since the economic shocks of such a scenario would likely lead to political unrest or worse. However unlikely it appears now, the threat or implementation of economic sanctions or a U.S.-led oil embargo that cut off (or significantly decreased) China's oil imports would almost certainly drive China to increase coal to oil production as quickly as possible. I believe the threat of such a possibility is one reason China is developing a coal to oil "technology reserve," a fact alluded to in a publication where two of China's leading scholars on the coal to industry 
stated that "Other than if China is subject a trade embargo because of political or economic reasons, coal to oil is not suitable for large scale development" (Sun and Xi, 2009, 8).

While one cannot predict the future, I believe both of these worst-case scenarios are unlikely to unfold in the near future, which is why I believe coal to oil will develop more slowly than experts were predicting in 2007 or 2008 ; such thinking is the background to anticipating that in the year 2020 China will only be producing somewhere between 10 and $15 \mathrm{mta}$. Irrespective of whether China is producing $10 \mathrm{mta}$ or $30 \mathrm{mta}$ in 2020, China's pursuit of a coal to oil industry has implications for China, the U.S. and the world, for better and worse. 